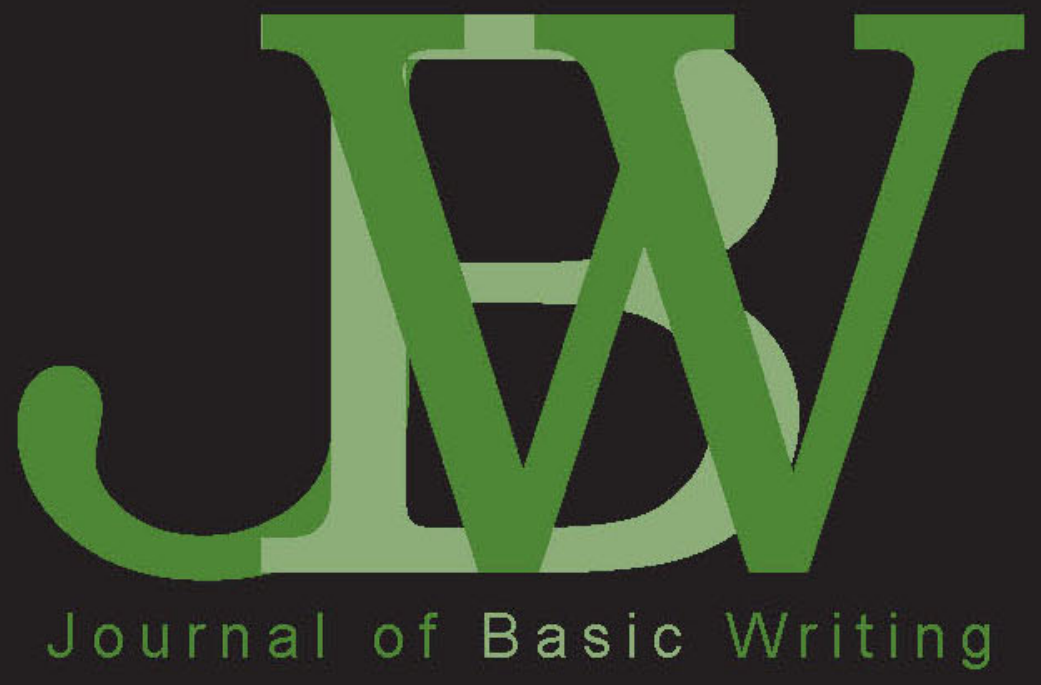

The City University of New York and the Shaughnessy Legacy:

Today's Scholars Talk Back

Judith Summerfield, Peter Gray, Cheryl C. Smith, Crystal Benedicks, Mark McBeth, Linda Hirsch, Mary Soliday, and Jessica Yood

Stretch at 10:

A Progress Report on Arizona State University's Stretch Program

Gregory R. Glau

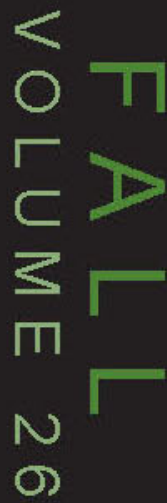

Re-Modeling Basic Writing

Rachel Rigolino and Penny Freel

Assessing Student Writing:

The Self-Revised Essay

Janine Graziano-King

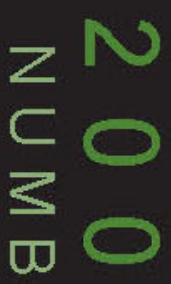

The Economy of Explicit Instruction

Don J. Kraemer

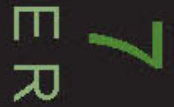


ISSN 0147-1635 


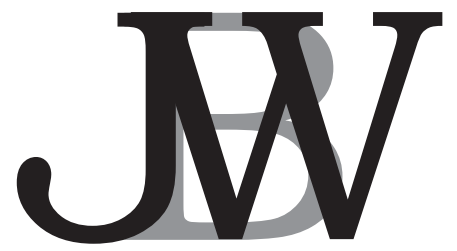

Journal of Basic Writing

VOLUME 26

FALL 2007

The Journal of Basic Writing publishes articles of theory, research, and teaching practices related to basic writing. Articles are refereed by members of the Editorial Board (see overleaf) and the Editors.

Rebecca Mlynarczyk and Bonne August Editors

\title{
Hope Parisi
}

Associate Editor

\section{Karen Weingarten and Angela J. Francis Editorial Assistants}

The Journal of Basic Writing is published twice a year, in the spring and fall, with support from the City University of New York, Office of Academic Affairs. We welcome unsolicited manuscripts and ask authors to consult the detailed "Call for Articles" in this issue. Subscriptions for individuals are $\$ 20.00$ for one year and $\$ 35$.00 for two years; subscriptions for institutions are $\$ 30$. oo for one year and $\$ 45.00$ for two years. Foreign postage is $\$ 10.00$ extra per year. For subscription inquiries or updates, contact:

\author{
Journal of Basic Writing \\ Attn. Cathie Ryan \\ 5 Sand Creek Road \\ Albany, NY 12205 \\ (800) 877-2693
}

Boyd Printing Company, Inc.

Published by the City University of New York since 1975

Cover and logo design by Kimon Frank

Copyright (C2007 by the Journal of Basic Writing

ISSN 0147-1635 


\section{JOURNAL OF BASIC WRITING}

\section{EDITORIAL BOARD}

Linda Adler-Kassner
Eastern Michigan University

Chris M. Anson

North Carolina State University

Hannah Ashley

West Chester University

David Bartholomae

University of Pittsburgh

Sarah Benesch

College of Staten Island, CUNY

Susan Naomi Bernstein

University of Cincinnati

Patricia Bizzell

College of the Holy Cross

Lynn Z. Bloom

University of Connecticut, Storrs

Gay Brookes

Borough of Manhattan Comm. College, CUNY

Richard Courage

Westchester Community College, SUNY

Martha Clark Cummings

Kingsborough Community College, CUNY

Donald A. Daiker

Miami University

Suellynn Duffey

Georgia Southern University

Chitralekha Duttagupta

Arizona State University

Sarah Warshauer Freedman

University of California, Berkeley

Keith Gilyard

Pennsylvania State University

Gregory Glau

Arizona State University

Laura Gray-Rosendale

Northern Arizona University

Karen L. Greenberg

Hunter College, CUNY

Brenda M. Greene

Medgar Evers College, CUNY

Susanmarie Harrington

Indiana University-Purdue University

Myra Kogen

Brooklyn College, CUNY
Patricia O. Laurence

City College of New York

Andrea A. Lunsford

Stanford University

Jane Maher

Nassau Community College, SUNY

Paul Kei Matsuda

University of New Hampshire

Geraldine McNenny

Chapman University

Susan Miller

University of Utah

Sandra Murphy

University of California, Davis

Deborah Mutnick

Long Island University

Nathaniel Norment, Jr.

Temple University

\section{George Otte}

Graduate Center, CUNY

Thomas Peele

Boise State University

Elizabeth Rorschach

City College, CUNY

Yolanda Sealey-Ruiz

New York University

Charles I. Schuster

University of Wisconsin, Milwaukee

Tony Silva

Purdue University

Trudy Smoke

Hunter College, CUNY

Ruth Spack

Bentley College

Lynn Quitman Troyka

Queensborough Comm. College, CUNY, ret.

Karen S. Uehling

Boise State University

Evelyn E. Webb

Miss. State Board for Comm. and Junior Colleges

Harvey S. Wiener

LaGuardia Community College, Emeritus

Vivian Zamel

University of Massachusetts, Boston 


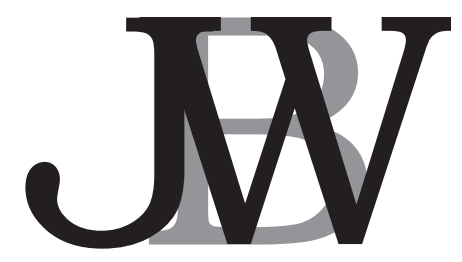

Journal of Basic Writing

VOLUME 26

NUMBER 2

FALL 2007

Editors' Column

The City University of New York and

the Shaughnessy Legacy: Today's Scholars Talk Back

Judith Summerfield, Peter Gray, Cheryl C. Smith, Crystal Benedicks, Mark McBeth, Linda Hirsch, Mary Soliday, and Jessica Yood

Stretch at Io: A Progress Report on

Arizona State University's Stretch Program

\section{Gregory R. Glau}

Re-Modeling Basic Writing

Rachel Rigolino and Penny Freel

Assessing Student Writing:

The Self-Revised Essay

Janine Graziano-King

The Economy of Explicit Instruction

Don J. Kraemer

News and Announcements 


\section{CALL FOR ARTICLES}

We welcome manuscripts of I5-25 pages, double spaced, on topics related to basic and ESL writing, broadly interpreted. Submissions should follow current MLA guidelines. Manuscripts are refereed anonymously. To assure impartial review, include name(s), affiliation(s), mailing and e-mail addresses, and a short biographical note for publication on the cover page only. The second page should include the title but no author identification, an abstract of about I5O words, and a list of 4-5 key words. Endnotes should be kept to a minimum. It is the author's responsibility to obtain permission for including excerpts from student writing.

We prefer that contributions be submitted as Word document attachments via email to: rebecca.mlynarczyk@gmail.com. If electronic submission is not possible, mail five copies of the manuscript and abstract to:

Professor Rebecca Mlynarczyk
Co-Editor, $J B W$
Department of English
Kingsborough Community
College, CUNY
2ooI Oriental Blvd.
Brooklyn, NY II235

\author{
Professor Hope Parisi \\ Co-Editor, JBW \\ Department of English \\ Kingsborough Community College, \\ CUNY \\ 20oI Oriental Blvd. \\ Brooklyn, NY II235
}

You will receive a confirmation of receipt; a report on the status of your submission will follow in about sixteen weeks.

All manuscripts must focus clearly on basic writing and must add substantively to the existing literature. We seek manuscripts that are original, stimulating, well-grounded in theory, and clearly related to practice. Work that reiterates what is known or work previously published will not be considered.

We invite authors to write about such matters as classroom practices in relation to basic-writing or second-language theory; cognitive and rhetorical theories and their relation to basic writing; social, psychological, and cultural implications of literacy; discourse theory; grammar, spelling, and error analysis; linguistics; computers and new technologies in basic writing; assessment and evaluation; writing center practices; teaching logs and the development of new methodologies; and cross-disciplinary studies combining basic writing with psychology, anthropology, journalism, and art. We publish observational studies as well as theoretical discussions on relationships between basic writing and reading, or the study of literature, or speech, or listening. The term "basic writer" is used with wide diversity today, sometimes referring to a student from a highly oral tradition with little experience in writing academic discourse, and sometimes referring to a student whose academic writing is fluent but otherwise deficient. To help readers, therefore, authors should describe clearly the student population which they are discussing.

We particularly encourage a variety of manuscripts: speculative discussions which venture fresh interpretations; essays which draw heavily on student writing as supportive evidence for new observations; research reports, written in non-technical language, which offer observations previously unknown or unsubstantiated; and collaborative writings which provocatively debate more than one side of a central controversy. 


\section{EDITORS' COLUMN}

Beginning with an article entitled "The City University of New York and the Shaughnessy Legacy: Today's Scholars Talk Back," this issue necessarily invites us to reflect on the early days of Open Admissions and, at the same time, to assess the current state of basic writing programs and pedagogy. This multi-authored article began as a panel at the Spring 2007 Conference on College Composition and Communication in New York City. Judith Summerfield, University Dean for Undergraduate Education, convened a group of compositionists from various CUNY campuses to examine the questions of the University's multiple identities within the legacy of Mina Shaughnessy, who coined the term "basic writing" and founded the Journal of Basic Writing in I975. The resulting article is a collage depicting the challenges and rewards of working with basic writers at the beginning of the twenty-first century in a climate that is now, as it was in the I97os, politically charged. Like Shaughnessy before them, today's scholars raise questions that force us to grapple with the very nature of literacy and democracy.

Of course, the Shaughnessy legacy is not limited to the City University of New York. In the I970s and beyond, basic writing programs came into being at many institutions across the country. In recent years, particularly in the I99os, these programs have been challenged and subjected to constraints and legislative mandates, which have inspired attempts to make BW programs more rigorous and intellectually challenging as well as more successful in institutional terms such as pass rates, retention rates, and student progress. This issue contains longitudinal reports on two such programs. And the news is promising. In "Stretch at Io: A Progress Report on Arizona State University's Stretch Program," Gregory R. Glau summarizes comprehensive data on the progress of nearly 8,ooo basic writers who have participated in this program. Designed to combat the "outsourcing" of basic writers to community colleges, the Stretch Program gives these students what they most need-more time. Time to think, time to write, time to revise, and-perhaps most crucially-time to assimilate into the new discourse communities they have entered. In a course sequence that "stretches" the work of first-year English over two semesters, students do the same reading and writing assignments as regular composition students and receive three hours of elective credit (for the first semester) and three hours of English credit (for the second semester). Based on a wealth of data collected over a ten-year period, the conclusion is clear: "the Stretch concept actually works and ... thousands of students have benefited from the extra time and guided writing experience they receive."

In "Re-Modeling Basic Writing," Rachel Rigolino and Penny Freel describe another approach to providing basic writing in the four-year college. The 
Supplemental Writing Workshop (SWW) Program was developed in I996 at the State University of New York (SUNY) at New Paltz to respond to public pressure to discontinue so-called remedial writing courses at four-year institutions. Like Arizona State's Stretch Program, the SWW Program has the same objectives and requirements as regular composition, carries academic credit, and gives basic writers more time to work on their writing. In the SUNY New Paltz program, however, the extra time is given in the same semester in the form of an integrated writing workshop and required tutoring sessions. Based on long-term institutional data on pass rates, retention rates, graduation rates, and GPAs, the students who began in the SWW Program are doing very well indeed when compared with other students entering at the same time. Commenting on the program's success, the authors explain, "[W]hat had begun as an effort to resist an impending exclusionary policy resulted in a robust curricular design that actually accelerated the progress of our basic writing students toward their Bachelor's degrees."

While large-scale change is taking place at the institutional level, concerned professionals continue to examine and improve aspects of classroom assessment and instruction. The last two articles exemplify this type of informed, reflective practice. In "Assessing Student Writing: The Self-Revised Essay," Janine GrazianoKing summarizes the major historical trends in writing assessment and suggests an alternative. Hoping, on the one hand, to reduce the "cognitive load" of instructors who assess student portfolios and, on the other, to assure that students are the "sole authors" of their work while at the same time providing "authentic" writing tasks that go beyond one-shot timed writing samples, she and a colleague have experimented with a new approach to writing assessment. "The self-revised essay" develops over time as a series of revisions of an essay based on an important course theme. At several different points during the term, students revise this essay during class time, expanding their initial draft by referring to additional course readings but without receiving teacher commentary or help from outside sources. Although further testing of this assessment method is clearly needed, Graziano-King feels that the self-revised essay has the potential to combine the best features of portfolios and timed essay exams.

In “The Economy of Explicit Instruction," Don J. Kraemer re-examines another important issue that every writing teacher faces-just how explicit to be in guiding student learning. The trend in recent years to encourage inquiry and student discovery has often led us away from the direct approach. In this article, Kraemer looks to his own practice in asking "whether to name for students what is important and what they must do." Struck by recent discussions of teaching that draw upon economic metaphors, Kraemer decided "to bring the economic more explicitly into [his] teaching and into [his] students' learning." 
He did so by asking his students to focus on problem formulation and rhetorical framing in Freakonomics by Steven Levitt and Stephen Dubner. This move, he argues, "added value" to his instruction. By requiring his basic writing students to read a challenging text and respond to it in certain ritualized ways, Kraemer encouraged "an economy of development," in which students could expand their notion of writing to communicate with new and different audiences for different purposes.

Taken together, the articles in this issue suggest that basic writing is alive and well in the twenty-first century despite the recent threats to its existence. The two reports based on long-term program assessment contain statistical evidence confirming that, given good instruction, basic writers can succeed at similar rates as other college students. The other articles exemplify the pedagogical creativity of scholars and teachers who are committed to working with students initially labeled as basic writers. It appears to us that, currently, some of the most innovative work in program and curriculum development is happening in the field of basic writing.

Finally, we would like to announce an upcoming change in the editorship of the Journal of Basic Writing. Beginning with the Spring 2008 issue, Hope Parisi, currently Associate Editor, will become Co-Editor along with Rebecca Mlynarczyk. Bonne August, who has co-edited the journal since the Fall of 2002, has decided to step down from this position. Her many responsibilities as Provost of CUNY's New York City Technical College have necessitated this decision. Speaking on behalf of $J B W$ 's Editorial Review Board as well as our authors and readers, Rebecca would like to thank Bonne for her unfailing wisdom and guidance over the past five years. We are grateful that we will still be able to call on her from time to time in her new role as Consulting Editor.

- Rebecca Mlynarczyk and Bonne August 


\title{
The City University of New York and the Shaughnessy Legacy: Today's Scholars Talk Back
}

\author{
Judith Summerfield, Peter Gray, Cheryl C. Smith, \\ Crystal Benedicks, Mark McBeth, Linda Hirsch, \\ Mary Soliday, and Jessica Yood
}

\begin{abstract}
To commemorate the 3oth anniversary of the publication of Mina Shaughnessy's groundbreaking book, Errors and Expectations, a roundtable discussion was held at the March 2007 Conference on College Composition and Communication in New York City. This article, based on the earlier discussion, examines the question of CUNY's multiple identities within the legacy of Shaughnessy, who coined the term "basic writing" and founded the Journal of Basic Writing in 1975. Composition theory and practice owe much to Shaughnessy's work at CUNY's City College in the I97os against the backdrop of the University's experiment with Open Admissions. Although much has changed since then, CUNY is still associated with that rich historical moment, and with the questions Shaughnessy and others at the time confronted. These questions, which grapple with the very nature of literacy and democracy, need to be reframed for our times. Contributors to this article include scholars from a number of CUNY's I7 undergraduate colleges, each of whom begins with a quotation selected to focus attention on an issue of relevance today.
\end{abstract}

KEYWORDS: Open Admissions; access politics; Mina Shaughnessy; City University of New York; literacy; democracy and education; basic writing; ESL

\section{Judith Summerfield}

"We classify at our peril. .. . It is our intention in the present research to describe stages in the development of writing abilities . . . a way of classifying that is both systematic and illuminating in the light it sheds upon the writing process itself."

-James Britton et al., The Development of Writing Abilities (I-3)

I want to talk about the contexts in which Mina Shaughnessy was writing, the company she was keeping in her reading and in the people she

Judith Summerfield, currently University Dean for Undergraduate Education at CUNY's Central Administration, is Professor of English at Queens College, CUNY. Her work in composition and rhetoric includes Texts and Contexts: A Contribution to the Theory and Practice of Teaching Composition, with the late Geoffrey Summerfield, and a winner of the MLA Mina Shaughnessy award. She oversees a number of University-wide initiatives to improve undergraduate education, including Writing Across the Curriculum.

(C) Journal of Basic Writing, Vol. 26, No. 2, 2007 
was talking to in the I970s, when she was doing her seminal research at City College. As a younger faculty in the mid-I970s, I knew of Shaughnessy, of course, but lived professionally in another of CUNY's senior colleges across the East River in the borough of Queens. (New York has five boroughs: Shaughnessy was teaching and doing her research in Manhattan.)

The times, as we know, were tumultuous: the Civil Rights Movement, the Women's Movement, the War on Poverty, Vietnam, desegregation, Black Panthers, Black English, an intense interest in language and in the teaching of English, both in the States and in Britain. I want to talk about the confluence of those two worlds. In I966, the Dartmouth Seminar was convened, a collaboration of NCTE and its British equivalent, NATE, and co-sponsored by the MLA. At this seminar, thirty-nine American, British, and Canadian scholars and teachers debated for two months over various perspectives on the teaching of English in an increasingly test-driven culture. They were especially concerned with how to put culture, language, and thought-and the individual learner-at the center of the debates.

Two conferences followed: the first held in York, England, in I97I, and the second in Sydney, Australia, in I98I. These two meetings were to take the work of Dartmouth further. A set of commissions grappled with critical questions of teaching English across the globe: teaching writing, literature, reading, and speaking; assessment; developing literacies across the curriculum for an increasingly diverse student body; and exploring the kinds of research needed for the work of K-I6.

Shaughnessy attended the I97I York conference. I know this from one of the participants, my late husband, Geoffrey Summerfield, a professor at the University of York and one of the conference organizers. The Development of Writing Abilities, based on the study conducted by James Britton and his team, was published in I975. Shaughnessy may have seen a draft of the book, I don't know, but I suspect that her work on classifying "error" was connected to the London Schools Council research on classifying student writing, with their explicit aim of changing the expectations of students' writing abilities, and therefore changing the ways English was being taught in the schools. That group of scholars and teachers wanted to make room for creativity, drama, and poetry, so that students would be able to write, as James Moffett put it, "a universe of discourse."

What's important here is to understand that these were then, as they are now, big questions about teaching English as a social, political, democratic act, and they need to be at the center of current debates about how to teach English in this increasingly global world. 
Britton's work, cited above, was a major project funded by a progressive government: the task was to demonstrate that the kinds of teaching and testing prevalent in the British schools narrowed expectations of what students can do and learn to do. There was an intense interest in language, in language play, in the imagination, and in exploring language-use in various contexts. Limit the curriculum, and you limit students' growth as users of language, as producers of knowledge. Shaughnessy's bibliography in Errors and Expectations lists two more works of Britton and his group as well as a host of other works that this community of international scholars was reading in common, creating an increasingly shared body of knowledge and research. They were defining, as Shaughnessy said, the "territory of language" (IO). We were reading across the disciplines, across traditional academic boundaries, from learning theory to structural grammar, anthropology to second-language learning, socio-linguistics, Russian formalism, literary criticism, and, of course, literary texts.

In I970, CUNY's Open Admissions experiment began. In that year, 35, ooo freshmen were admitted to CUNY, seven times the number of firstyear students allotted the year before. Shaughnessy, an English instructor at the City College of New York (a CUNY senior college) who had been director of the SEEK (Search for Education, Elevation, and Knowledge) Program for financially disadvantaged Black and Puerto Rican students, was named Director of the Writing Program. CUNY became the laboratory for one of the most daring experiments in the history of higher education, and Shaughnessy, a leader in recharting the territory in the teaching of writing. Her research, supported by the Carnegie Foundation, received national attention and still engenders intense debate. To read Shaughnessy's work as solely about error analysis is to miss the larger political significance: As Janet Emig put it, Shaughnessy's "commitment [is] to the infinite possibility of the individual" (qtd. in Maher I29).

But by the time Errors and Expectations was published in I977, the "pure phase of the experiment," as Lavin and Hyllegard put it, had passed (20). In I976, the New York City fiscal crisis precipitated profound changes within the University - faculty were dismissed; programs such as the basic writing program at City College dismantled. In a I976 address to the Conference of the CUNY Association of Writing Supervisors (CAWS) that she calls the "The Miserable Truth," Shaughnessy speaks of the University "shak[ing] and fractur[ing] under the blows of retrenchment." These are "discouraging times for all of us," she says (qtd. in Maher, 264). Shaughnessy and a group 
of fellow compositionists were asked to participate in a Writing Task Force to create the first CUNY-wide Writing Assessment Test (WAT).

It took, however, another twenty years for Open Admissions to be officially ended at CUNY's senior colleges. ${ }^{1}$ The WAT exam was replaced by a nationally normed "CUNY/ACT Writing Sample" test. And at the same time, resources were provided to a new University-wide Writing Across the Curriculum program, mandated by CUNY's Board of Trustees. The CUNY scholars represented in this article are all taking part in what has become a vital transformative project about teaching writing in the $2 \mathrm{I}^{\text {st }}$ century-and paying tribute today to our rich legacies.

In England, the London Schools Council project initiated a Writing Across the Curriculum program in I977, but the times changed, and the work devolved into a competency-based school regime, which lasts to this day. I understand, though, that some Brits are now rediscovering Britton and his work. I'm certain there's a panel going on somewhere on the importance of the Britton legacy, with today's scholars "talking back."

These are not small issues, and as we look back, we remember that the stakes were and are still high for ourselves, our students, and the culture.

\section{Works Cited}

Britton, James, Tony Burgess, Nancy Martin, Alex McLeod, and Harold Rosen, The Development of Writing Abilities (II-I8) (A report from the Schools Council Project on Written Language of II-I8 Year Olds.) London: Macmillan, I975.

Lavin, David, and David Hyllegard. Changing the Odds: Open Admissions and the Life Chances of the Disadvantaged. New Haven, CT: Yale UP, I996.

Maher, Jane. Mina P. Shaughnessy: Her Life and Work. Urbana, IL: NCTE, I997.

Moffett, James. Teaching the Universe of Discourse. Portsmouth, NH: Boynton-Cook, I987.

Shaughnessy, Mina P. Errors and Expectations: A Guide for the Teacher of Basic Writing. New York: Oxford UP, I977.

\footnotetext{
I. Editors' Note: On May 26, I998 (and again on January 25, I999, after a legal challenge to the first vote), CUNY's Board of Trustees voted to phase out all "remediation" in its fouryear colleges by January 200I. In practice, this meant that only students who passed all three of the University's assessment tests (reading, writing, and math) upon entrance could be admitted to a bachelor's degree program in one of the four-year colleges. Others would have to begin their studies in an associate's degree program or in one of the University's community colleges.
} 


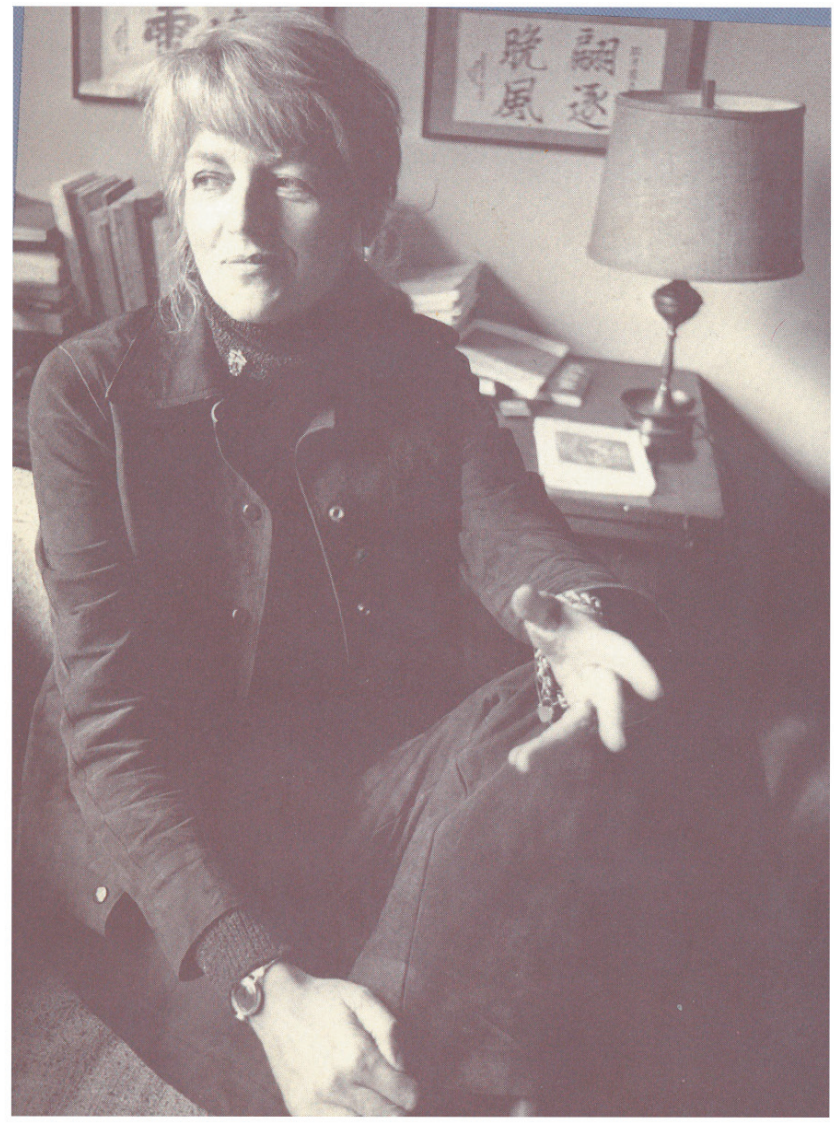

Mina P. Shaughnessy 


\section{Peter Gray}

"When we say our students' writing is literature, we are asked, How do you define literature? Here the definition is simple. What we pay attention to is literature."

-Marie Ponsot and Rosemary Deen, Beat Not the Poor Desk (70)

Where Shaughnessy focused on errors of language use and challenging teachers to understand newly their notions of "error," across the Queensborough Bridge and the East River, and down the Long Island Expressway to Queens College, Marie Ponsot and Rosemary Deen were busy working, to put it bluntly, to undo the damage of Shaughnessy's focus on error and usage. In their widely regarded (at the time, but now largely forgotten) book, Beat Not the Poor Desk, Ponsot and Deen created a program of teaching that is a direct challenge to, and an indirect critique of, the entire project Shaughnessy creates in Errors and Expectations.

Beat Not the Poor Desk is based on two broad ideas that constitute this critique and that sets out their own aims. First, as they write in their preface, they want, rather simply, to have teachers teach and writers write, beginning with student writing that is not drills based. Second, Ponsot and Deen exhort teachers to make use of their literary studies training: "Because we know what literature is, we ought to be able to set up an elementary writing course on elemental literary principles.... We don't have to starve ourselves of literature just because we are teaching inexperienced writers. We can use all we know to teach them. But not directly" (8). Ponsot and Deen wanted novice writers to work with "shapes found in literature of the oral tradition, for these shapes have by their spontaneous recurrence and long survival... proven that they are congenial to the human mind. It is a natural, central starting place" (Ponsot 33). Suggested shapes include "[f]ables, riddles, sermons, curses, epitaphs, prayers, anecdotes, proverbs, spells and charms, laws, invective-all are quintessential structures" (Ponsot and Deen 5). This pedagogy invited teachers to abstract their own structures from literature and to "present these structures in seed sentences for writers to imagine in their own versions" (Ponsot and Deen 4). This made sense for a good many who were teaching in the SEEK program with them at Queens College; it was a

Peter Gray is Associate Professor of English at Queensborough Community College, CUNY, where he co-directs the Writing Across the Curriculum Program. His current work includes participation in a CUNY-wide Carnegie CASTL project and a pilot graduate interdisciplinary pedagogy seminar. 
program that offered full employment for many poets, novelists, playwrights who, with Ponsot and Deen, cultivated the ideas that grew into Beat Not.

Ponsot and Deen, however, shared with Shaughnessy an advocacy for students that was grounded in commitments to open access to higher education, and they, like their colleague at City College, believed in the "promise that to learn skill is to take on power proper to us" (Preface). Ponsot and Deen emphasize over and over again the importance of respecting students and of taking their writing seriously; doing so demonstrates their "deepest conviction": "that we are not different from our students in any important way" (IO).

Read through today's eyes, Beat Not is a vision of the process movement as literary formalist poetics. The book rejects Shaughnessy's attention to understanding error newly as a method to teach writing because doing so circumscribes the writers' imaginations with what they call in their preface "teachers' [already formed] analytic conclusions." In a recent interview, Ponsot explains her alternative method, one that is foundational to Beat Not: teachers should give "people things to do that you would be willing to read as literature. [Student] papers will have a literary structure because you will not have asked for well-punctuated sentences or grammatically varied sentences, what a dreadful thing to tell students to do, awful. They will be good, readable, literary sentences because you will have said, 'Write me something brilliant, write me something elegant"' (Ivry 54).

Placing Ponsot and Deen next to Shaughnessy is to see a very early version of later debates English Studies began to wrestle with in earnest throughout the I99os: Can we usefully negotiate rhetoric and poetics at the site of literacy instruction? Can a formalist poetics, or any poetics for that matter, be reconciled with liberatory, social politics and pedagogies that extend the legacies of colleagues working during the Open Admission years at CUNY and elsewhere across the country and that we have begun to articulate variously for first-year writing programs? How might we reinvigorate the "literary" as an object and a means of study?

\section{Works Cited}

Ponsot, Marie, and Rosemary Deen. Beat Not the Poor Desk: Writing: What to Teach, How to Teach It and Why. Upper Montclair, NJ: Boynton/Cook, I982.

Ponsot, Marie. "Total Immersion." Journal of Basic Writing I.2 (I976):3I-43. Ivry, Benjamin. "Marie Ponsot Interview." BOMB No. 83 (Spring 2003): 50-55. 


\section{Cheryl C. Smith}

"We have been trained to notice what students learn, not how they learn it, to observe what they do to writing, not what writing does to them."

-Mina Shaughnessy, "Open Admissions and the Disadvantaged Teacher" (403)

Shaughnessy wrote these words in 1973, three years after Open Admissions had begun at CUNY's City College. Errors and Expectations, published seven years after the start of Open Admissions, documents how quickly the new policy had impacted CUNY's undergraduates and their relationships to language. During this tumultuous time, Shaughnessy witnessed and responded to changes in her classes, institution, and roles as teacher and administrator. More than three decades later, I see Shaughnessy's words as strikingly relevant to my work at CUNY. I arrived at Baruch College in September 2003, only two years after the end of remediation had gone into effect, requiring applicants for baccalaureate programs to meet minimum levels on standardized tests in math and English. Six years into this new admissions policy, we find ourselves in another tumultuous time, not entirely unlike that of Shaughnessy. Shifts in students' academic backgrounds and goals, along with adjustments to entrance requirements, have put some undergraduates into precariously marginalized spaces, admitted to college but not prepared, and possibly not permitted, to take certain core courses. How do faculty respond to the needs of an institution in flux and work with the students wedged into gaps created by significant adjustments in admissions protocol? Are we going to dismiss them as incapable or try to understand their patterns of error and the impact of our expectations?

Amidst all the turmoil of policy change, what makes this quotation from Shaughessy most relevant to me now is its call to be more aware of the processes of students' learning-how they learn-and the effects of our teaching-what it does to them. Shaughnessy urges us to step back from the tumult and remember one of the basics of teaching and learning: to ap-

Cheryl C. Smith is assistant professor of English and Writing Across the Curriculum (WAC) faculty coordinator at Baruch College. Her scholarly interests are writing program administration, curricular change and pedagogical innovation, cross-disciplinary faculty development, and early American women's political writing. Her recent work has appeared in the Journal of American Culture, Reclaiming the Public University: Conversations on General and Liberal Education, and a forthcoming article in Teaching North American Environmental Literature. 
proach our students with respectful curiosity about what they hear in our assignments, our comments, our grades and standards. When we know how they internalize the language of the academy, we can tailor our practices and respond to their writing in ways that take into account their experiences and perspectives on academic work.

In reminding us of the importance of considering student experiences and perspectives, Shaughnessy taps into notions central to the current movement around the scholarship of teaching and learning (SoTL) - yet another testament to how strikingly ahead of her time she was. When Ernest Boyer published Scholarship Reconsidered in I990, pushing the academy to make teaching as important as research in faculty priorities and promotion, he effectively launched the SoTL movement that has gained momentum in recent years. Shaughnessy anticipates this movement by nearly two decades. To remind us to be more aware of how students learn and what writing does to them is to foreground three main needs: first, to analyze our students' learning continually, and in new ways; second, to be as critical of our teaching as we are of their learning; and third, to keep up with changes in our students and the world when it comes to language, reading, and writing. These needs reflect SoTL's mission and Shaughnessy accomplishes all three in Errors and Expectations when she examines patterns of student error to advance an argument not only about student literacy but also faculty expectations, and how both play out in our nation's changing classrooms.

To honor Shaughnessy's legacy thirty years after the publication of her groundbreaking book, we should follow her lead and examine our classroom practices, their processes and effects. In the title of the essay from which the above quotation comes, "Open Admissions and the Disadvantaged Teacher," she subverts the idea of disadvantage in our schools. It is less important that Open Admissions introduced new kinds of under-prepared students to college than that the teachers themselves were newly under-prepared and therefore disadvantaged. Shaughnessy repeatedly foregrounds faculty "deficiencies" and "maladies" to argue that we writing teachers need remediation ourselves, to be put on our own "development scale" as she puts it in "Diving In: An Introduction to Basic Writing" (234). It is a message that faculty may not want to hear-and understandably so. Professional remediation to analyze and correct our deficiencies? We feel crunched enough by heavy teaching loads and needy students. How can we be expected to put more time into that single aspect of our workload when so many other tasks clamor for our attention? Even Shaughnessy concedes that the decision to dive in to our own remediation process as teachers "demands professional courage" 
("Diving" 238), suggesting that teaching can be at odds with other faculty concerns, especially research, and may in turn put those who emphasize teaching at odds with their colleagues, departments, and institutions.

But today at CUNY and across the nation, students are changing, and our teaching has to keep up with the changes. Faculty have to manifest professional courage and institutions have to support it, or our students will not reach their full potential. For instance, the work of helping current undergraduates comprehend and engage demanding reading materials continues to get more and more complicated by the increasing diversity of students' languages and the nature of their exposure to reading. Professors-who want to ensure that students receive the "correct" reading of a text-may focus, as Shaughnessy argues, on what students learn over how they learn it. In our teaching practice, we can be tenacious in looking for the what: the content knowledge. We ask ourselves again and again, did students get the assigned reading? Did they understand the study's results, the novel's plot, the article's point? Then, as our students fail to demonstrate such knowledge, we fail to see our own disadvantaged way of framing their understanding in the first place. In not accounting for the complex processes of learning, we miss opportunities to optimize it by, for example, fostering deeper student-led discussion, assigning more in-class writing, or regularly using group work as a means to help students comprehend difficult course materials. Such techniques enable teachers to create the student-centered classrooms that more flexibly adapt to undergraduate experiences and perspectives. Sometimes we need a dose of pedagogical remediation to remind ourselves of the alternative roads to learning.

Since the end of remediation in CUNY's four-year, or senior, colleges, it has become more and more important to remain aware of these alternative roads to learning. Shortly after the end of remediation, increasingly competitive admissions standards began to be put in place, having effects we can not afford to ignore on the classroom level. One effect concerns the relationship between the two- and four-year colleges. If the higher standards draw better-prepared students to the senior colleges, a larger number of less-prepared students will be directed to the system's community colleges, which need to have programs and staff in place to handle the changes. Furthermore, these same students may well come to one of the senior colleges within a few short semesters. Transfer students comprise more than half of Baruch's graduating class each year, a statistic true for many of CUNY's baccalaureate-granting institutions. The undergraduate experience in the twenty-first century-especially in a large, diverse commuter system like 
CUNY - has become remarkably fluid. As a result, we can no longer look at what we do to engage students and improve their performance in isolation, on our individual campuses; we have to talk to our colleagues throughout the system to understand their work and challenges. Once we do, we can improve articulation between our programs and ease the transition of the many undergraduates who transfer between schools every year. Meanwhile, in some cases students still get provisionally admitted to a senior college without meeting minimum basic skills requirements in English. Since the end of remediation, however, such students have dwindling options. They most often get relegated to non-credit courses that prepare them to take and retake the system's standardized writing and reading tests, which they desperately need to pass in order to fully enroll in an undergraduate course of studies. For them, the tests are less a learning experience than a hurdle-a dreaded and often demoralizing bridge to the first-year composition class that brings them into their college writing experience with a sense of failure rather than potential. At my school, SAT scores and other indicators tell us that new students' preparedness and pre-college academic performance are improving overall; nevertheless, CUNY continues to serve an economically and linguistically diverse city population that brings an exciting yet complicated mix of educational experiences, languages, fluencies, and literacy levels into the system's classrooms.

Because we encounter such a complex set of undergraduate experiences and needs in the twenty-first century school, it is especially incumbent upon us to regularly take stock of who is there, how they are doing, and what we are doing. In my view, this involves approaching teaching as a scholarly activity where meaningful gains in our pedagogy are always to be had and can be achieved in two main ways. First, we should be opening up our classrooms and their practices to more ongoing conversation that leads to experimentation and innovation. A crucial step toward realizing such innovation is building communities of practice both in and across the disciplines, as well as across campuses, where faculty talk to one another about teaching and learning. Equally crucial is building time into faculty workloads for participation in these communities. Second, we should be actively fostering greater awareness about how our students are changing, along with acceptance of and accommodation to how they are changing our institutions and some of the most important work that we do. It is not enough, for example, to celebrate CUNY's rising standards as improving the value and competitiveness of the University's degrees, or to bemoan those standards for denying access to under-represented groups and reneging on the University's historical 
mission. These opposing views, so familiar in the years surrounding Open Admissions and then again at the end of remediation, have resurfaced in recent months as we grapple with the issue of raising competency levels in math (Arenson; Posamentier). Do more stringent requirements for admission to CUNY's top-tier schools motivate the most capable students to perform at a higher level and reward them with a more competitive degree, or do such requirements block deserving yet less-prepared students from an opportunity to prove themselves at the college of their choice? CUNY's longstanding commitment to providing fair and equitable access to a quality public higher education should inspire us to keep these critical debates open-but we also have to pay attention to how the debates shake out, semester to semester, in our classrooms. Shaughnessy's work reminds us that our careful attention to classroom dynamics, along with the subsequent changes to how and what we teach, can have the most immediate impact on the standards and missions we defend so passionately.

\section{Works Cited}

Arenson, Karen. "CUNY Raising Admissions Standards with Higher Math Cutoff." New York Times 28 July 2007: BI.

Boyer, Ernest L. Scholarship Reconsidered: Priorities of the Professoriate. Princeton, NJ: Princeton UP, The Carnegie Foundation for the Advancement of Teaching, I990.

Posamentier, Alfred. "Standards Aid CUNY Students." New York Post 20 Aug. 2007: 27.

Shaughnessy, Mina P. "Open Admissions and the Disadvantaged Teacher." College Composition and Communication 24.5 (I973): 4OI-O4.

__. "Diving In: An Introduction to Basic Writing." College Composition and Communication 27.3 (1976): 234-39.

_. Errors and Expectations: A Guide for the Teacher of Basic Writing. New York: Oxford UP, I977. 


\section{Crystal Benedicks}

"Iust how we are finally going to reconcile the entitlements and capacities of these new students with our traditional ways of doing things in higher education is still not clear. As we move closer to this goal, however, we will be improving the quality of college education for all students and moving deeper into the realizations of a democracy."

-Mina Shaughnessy, Errors and Expectations (293-94)

This quotation-about the challenge of reconciling the entitlements and capacities of open access students with our traditional ways of doing things-takes me to one of the most traditional of our ways of doing things in the academy: doctoral education. Here I speak as a recent doctoral graduate with a specialty in Victorian poetry, and also as a newly hired faculty member teaching composition at an open-access community college. I believe many professors in English or even other fields are in the same position: the traditional way of doing things (research for the Ph.D.) doesn't match up with the non-traditional spaces (the composition classroom) in which we find ourselves.

Cheryl Smith has connected Shaughnessy's work with the scholarship of teaching and learning. I want to pick up there, and extend the idea to future college teachers who are, literally, still students.

There is a strong but unexplored relationship between the attitudes that Shaughnessy tells us drive meaningful teaching and the scholarly attitudes emphasized in traditional doctoral education. Shaughnessy advocates close readings of student texts: doctoral students spend their time analyzing literary or theoretical texts. Shaughnessy questions established administrative and curricular structures: doctoral students study literary structures as well as the structural logic of period divisions and canon formations. Shaughnessy reminds us of the importance of considering the social, political, and economic contexts that shape our understanding of higher education and who it is for: doctoral students draw attention to similar contexts for their objects of study.

And the dissertation itself-that most wrenching of writing assignments-is ripe ground for considering questions of audience, of what is lost

At the time of the CCCC presentation, Crystal Benedicks was serving as Assistant Professor of English at CUNY's Queensborough Community College. She is currently a Visiting Assistant Professor at Wabash College in Crawfordsville, Indiana. She received her doctorate in 2005 from the CUNY Graduate Center. 
or gained in taking up the language of authority, of the uneven process that is writing, of the ways in which available grammatical and organizational structures shape the ideas we have to express. All of these are questions that beginning writing students face, and that we ought to talk about in classes both doctoral and remedial.

We must find ways to make the links between studying to become a professor and teaching writing explicit, for traditional doctoral education in English does not prepare teachers to teach basic, or even introductory, writing. I am fortunate to have attended the City University of New York Graduate Center, where graduate students routinely teach composition and basic writing at one of CUNY's undergraduate colleges from their first day of graduate school. Even so, many new members of the professoriate-myself included-go through what Patrick Bizzaro has called "an identity crisis," schooled in literary analysis but teaching writing to beginning students. For Shaughnessy, the challenge of reconciling the traditional conception of the academy with the reality of educating all students is worthwhile because on it rests the ideal of democracy itself: that all students ought to have access. This only works if the scholarship of teaching writing is taken seriously by the doctoral curriculum that prepares the teachers who educate within the democracy.

\section{Works Cited}

Bizzaro, Patrick. "What I Learned in Grad School, or Literary Training and the Theorizing of Composition." College Composition and Communication 50.4. (1999): 722-42.

Shaughnessy, Mina P. Errors and Expectations: A Guide for the Teacher of Basic Writing. New York: Oxford UP, 1977. 


\section{Mark McBeth}

"This is not an interesting memo-but it's important. In fact, if you don't read it, some part of the fragile machinery that moves us . . will probably break down."

-Mina Shaughnessy, Memorandum, December I7, I97I

Richard Miller in As If Learning Mattered contends that the work of the compositionist does not begin in the classroom but in its preliminary construction. He writes:

[T] hose truly committed to increasing access to all the academy has to offer must assume a more central role in the bureaucratic management of the academy.... it is at the microbureaucratic level of local praxis that one can begin to exercise a material influence not only on how students are represented or on which books will be a part of the required reading lists but also, and much more important, on which individuals are given a chance to become students and on whether the academy can be made to function as a responsive, hospitable environment for all who work within its confines. (46)

Miller underscores the importance of programmatic structures and how compositionists must understand them if those "responsive, hospitable environment[s]" are in reality to materialize into successful instructional endeavors. Miller deems certain educational leaders as "intellectual-bureaucrats," and his description aptly portrays Shaughnessy.

Marilyn Maiz, Shaughnessy's assistant, told me in a personal interview that for Shaughnessy "administration wasn't the thing she was vitally interested in but she felt it was very important.... For Mina, it was just a very human thing. It wasn't like administration was separate from these other things [teaching, scholarship, classrooms]. It was just all part of the package" (Personal Interview). In "Intellectual Wasteland," Richard Miller suggests that " $[\mathrm{b}] \mathrm{y}$ learning to look at the business of writing instruction from the

Mark McBeth teaches as an Associate Professor at John Jay College of Criminal Justice, where he is also Deputy Chair for Writing Programs and Writing Across the Curriculum Coordinator. His scholarly interests intersect the history of education, curricular design, and writing program administration as well as sociolinguistics. 
administrator's view, it is possible that, in addition to finding ways both to rewrite the history of the discipline and to redefine the focus of classroom research, we might just uncover ways to materially change the working conditions of those who teach writing" (25). The ways in which Shaughnessy's administrative and pedagogical work informed her scholarship of the basic writers of early Open Admissions should redefine how we approach the bureaucratic work that compositionists must inevitably perform.

Shaughnessy's historical legacy as a Writing Program Administrator (WPA) demonstrates that one need not be solely the paper-pushing Bartleby the Compositionist, but that, in fact, the knowledge, ingenuity, and charm that one brings to administrative tasks complement our teacherly work and may substantiate our scholarly endeavors as well. In other words, the ofttedious bureaucratic labors we will inevitably face may not deter us from the publish-or-perish work we need to complete, but, on the contrary, may lead us to it. Applying our scholarly scrutiny and creativity to the administrative positions we hold may prove to make the WPA's labors both more fruitful and possibly more rewarding (perhaps even pleasurable).

\section{Works Cited}

Maiz, Marilyn. Personal Interview. I2 February 2004.

Miller, Richard E. As If Learning Mattered: Reforming Higher Education. Ithaca, NY: Cornell UP, I998.

"From Intellectual Wasteland to Resource-Rich Colony: Capitalizing on the Role of Writing Instruction in Higher Education," Writing Program Administration 24.3 (200I): 25-40.

Shaughnessy, Mina. "Memorandum to Instructors (December I7, I97I)." Archives and Special Collections, Morris Raphael Cohen Library, The City College, City University of New York. 


\section{Linda Hirsch}

"College both beckons and threatens them, offering to teach them useful ways of thinking and talking about the world, promising even to improve the quality of their lives, but threatening at the same time to take from them their distinctive ways of interpreting the world, to assimilate them into the culture of academia without acknowledging their experiences as outsiders."

-Mina Shaughnesssy, Errors and Expectations (292)

Written thirty years ago, Shaughnessy's words reminded her readers that the "culture of academia" was both enticing and threatening to the students she named "basic writers," requiring them to reconcile the rival claims of their non-school literacies such as dialects and first languages, and academic literacy, the language of the classroom (Courage). Today, against a backdrop of a greater diversity of English-language users and a II $8 \%$ increase in the number of homes speaking a language other than English during the period from I979 to I999, CUNY and in particular its community colleges confront the challenge of enabling students to value and draw on their own cultural resources and non-school literacies as they develop the academic literacies required for success in the university and beyond.

From the early I970s, when Open Admissions allowed many secondlanguage learners to enter the University, ESL writing pedagogy has moved from an emphasis on error correction and contrastive analysis through process writing to today's discourse analysis. In Errors and Expectations, Shaughnessy described the tension between content and form, a tension still with us today:

While we must dismiss as irresponsibly romantic the view that error is not important at all ... we should also be wary of any view that results in setting tasks for beginning writers that few besides English teachers would consider important.... This emphasis upon propriety ... has narrowed and debased the teaching of writing, encouraging at least two tendencies in teachers-a tendency to view the work of their students microscopically, with an eye for forms

Linda Hirsch is Professor of English at Hostos Community College/CUNY. She has published on the use of writing and speaking throughout the disciplines for English-language learners and is currently the Coordinator of the Writing/Reading Across the Curriculum Initiative at Hostos. 
but with little interest in what was being said, and a tendency to develop a repugnance for error that has made erring students feel like pariahs. ... (II9-20)

Since Shaughnessy's time, issues of identity, multiple literacies, and technology have shaped second-language (L2) composition while at the same time influencing students' perceptions of themselves as learners and writers. What does it mean to acquire language? Language seems more than the standard definition of "a system that consists of sounds combined to form sentences that combine to form discourse." To be effective language users, learners must acquire an understanding of culture and pragmatics, the knowledge of how to use language to get things done in the world. Acquiring academic language proficiency is an even greater challenge. Studies have repeatedly shown that it takes five to seven years for ESL students to acquire the academic language proficiency of a typical native-speaker (Collier). Shaughnessy's legacy encompasses some of these changing views of language acquisition. Her proposal to look at student writing problems "in a way that does not ignore the linguistic sophistication of the students nor yet underestimate the complexity of the task they face as they set about learning to write for college" (I3), and her analysis of the logic of students' writing errors, came to influence Li composition research and later research into L2 composing processes.

During the last thirty years, language policies, many seeking to restrict access to higher education, have raised issues of how ESL is defined-linguistically, educationally, politically, and socially. In turn, these definitions have affected ESL pedagogy. Today introductory composition classes might contain ESL students (including the newly labeled Generation I.5), basic writers, and students of nonstandard dialects. Underlying these heterogeneous groupings is an assumption that the different language and language learning needs of ESL students are not unique and can be addressed within the context of a broader linguistic diversity. Mainstreaming ESL students thus minimizes the need to address ESL as a distinct curriculum issue. Constant Leung's 2003 study in the United Kingdom, "Integrating School-Aged ESL Learners into the Mainstream Curriculum," asserts that the integration of ESL students into the mainstream is ideologically rather than pedagogically driven and notes that curriculum approaches adopted by policy makers are not always influenced by professional experience or research. It seems reasonable to question if recent decisions in CUNY and, indeed, across the United States to 
mainstream ESL students are based on sound educational grounds or might instead be the result of other ideological or political concerns.

In the years ahead, English departments and writing programs will need to explore ways to respond to the needs of linguistically and culturally diverse student populations. CUNY's Open Admissions policy and its subsequent elimination from the senior colleges would indicate that over the past thirty years we have not found or defined Shaughnessy's "territory of tolerable error" (I22) and have not reached any consensus as to what college-level writing is and how it can be meaningfully and fairly assessed.

Since the publication of Errors and Expectations, a growing body of research has enriched our understanding of student writing processes, but there remains much that it is still unknown about ways of ensuring the success of students who are not proficient in English. While much ESL composition pedagogy has drawn on research in LI, compositionists have not availed themselves of research in second-language acquisition that might have a positive impact on all learners in their classrooms. Silva, Leki, and Carson point out that unlike writing classrooms for monolingual speakers, second-language writing classrooms assume that "writers are heterogeneous. ... they are all developmental in that their tackling of academic writing will be a new experience; they will achieve differing ultimate success in their second language; they bring to the classroom specific culturally determined educational, social, and linguistic characteristics to which they claim an undisputed right and to which academic English is merely one addition" (424). Yet teachers of heterogeneous composition classes may have little knowledge of second-language perspectives. If mainstreaming is to succeed, if college is to beckon more than it threatens, then educators must enter our classrooms better versed in studies of language and culture and the interplay of linguistics and composition.

In addition, the success of all writers might be further enhanced by classroom pedagogies that acknowledge and build on the reciprocity between reading and writing. While many college writing assignments draw on readings, not enough attention has been paid to the difficulties students have in accessing and making sense of these works. Both first- and second-language writers would benefit from receiving instruction in reading across a variety of texts and genres and in classes throughout the curriculum.

In 1977, Mina Shaughnessy gave eloquent expression to our need to reexamine how we teach and how we view the capabilities of the untraditional college students then entering CUNY's campuses. Her advice to "grant 
students the intelligence and will they need to master what is being taught" (292), and to consider our own mistakes and inadequacies in the teaching process is no less relevant today. Our abilities as teachers and as scholars to address the needs of today's multilingual, multicultural students will surely define the University in the decades to come.

\section{Works Cited}

Collier,Virginia P. "Acquiring a Second Language for School." Directions in Language and Education I.4 (1995).

Courage, Richard. "The Interaction of Public and Private Literacies." College Composition and Communication 44.4 (I993): 484-96.

Leung, Constant. "Integrating School-Aged ESL Learners into the Mainstream Curriculum." The International Handbook of English Language Teaching. Ed. Jim Cummins and Chris Davison. New York: Springer. 2007. 237-69.

Shaughnessy, Mina P. Errors and Expectations: A Guide for the Teacher of Basic Writing. New York: Oxford UP, I977.

Silva, Tony, Ilona Leki, and Joan Carson. "Broadening the Perspective of Mainstream Composition Studies: Some Thoughts from the Disciplinary Margins." Written Communication, I4.3 (I997): 398-428. 


\section{Mary Soliday}

"We reject in our bones the traditional meritocratic model of a college." -Mina Shaughnessy, “The Miserable Truth” (269)

Since I979, Mina Shaughnessy's critics have argued that she urged students to assimilate to correct school forms rather than investigating the possible cultural changes students would experience as a result of this assimilation. It has also been suggested that Shaughnessy's views reflected the basic assumptions of CUNY's original Open Admissions policy: the students had to change and not the university (e.g., Rouse; Gunner; Horner and Lu).

Shaughnessy's critics often view language through the lens of identity politics, a perspective dominant in the academy in the I990s and still influential in composition studies today. In this framework, writers express their identity primarily through their cultural heritage and especially through language. A CUNY student who brings with her to college a nontraditional dialect or second language is likely to experience a cultural clash between the identity associated with her "home" language and that of the socially and linguistically more powerful academy.

In Errors and Expectations, Shaughnessy acknowledged the role this cultural struggle played for basic writers (292), but she did not develop a curriculum based on struggle because she viewed language through the lens of access politics. Shaughnessy was concerned with making sure nontraditional students had direct access to traditional education. She was less interested in reforming the traditional curriculum, partly because she thought curriculum would change once nontraditional students were aggressively integrated into the academy. At City College, she hoped to institutionalize access by establishing a direct avenue between remedial and liberal arts courses and by professionalizing the new field of basic writing

Though not without its practical dimensions, Open Admissions in I970 was in many ways a radical response to the enduring problem of social inequality. Labor historian Joshua Freeman argues, for instance, that open access to CUNY was accomplished by a municipal coalition that pushed for greater privileges for working- and middle-class people in terms of wages,

Professor of English at the City College of New York, Mary Soliday is the author of The Politics of Remediation (U of Pittsburgh P, 2002), which received the CCCC Outstanding Book Award for 2004. She has recently completed Everyday Genres: Readers and Writers Make Assignments Across the Curriculum. 
housing, and education. Momentarily, he concludes, the coalition crossed lines of race, class, and gender to demand that CUNY de-stratify its institutions and enable students to move freely between colleges in the system. For a brief moment, CUNY really did challenge the traditional model of college, and I don't think the challenge has been repeated. On the contrary, since the I99os, CUNY (and public higher education more generally) has re-stratified itself by abolishing remediation in four-year schools and creating a rising junior exam, an honors college, and stiffer entrance requirements in English and mathematics.

Meanwhile, in our profession, we tend to represent our students as members of singular cultural groups distinguished by ethnic, linguistic, or religious differences. I worry that the broader language of solidarity, democracy, and challenge that was typical of Shaughnessy and many of her CUNY colleagues has vanished from the scene. I worry too that basic writing programs are losing visibility in four-year institutions and thus in our mainstream professional discourse. Do we still desire in our bones to challenge the traditional model of college? Or, does this challenge now belong to its historical moment?

\section{Works Cited}

Freeman, Joshua. Working-Class New York. New York: The New Press, 2000. Gunner, Jeanne. "Iconic Discourse: The Troubling Legacy of Mina Shaughnessy." Journal of Basic Writing I7 (I998): 25-42.

Horner, Bruce, and Min-Zhan Lu. Representing the "Other": Basic Writers and the Teaching of Basic Writing. Urbana, IL: NCTE, I999.

Maher, Jane. Mina P. Shaughnessy. Urbana, IL: NCTE, I997.

Rouse, John. "The Politics of Composition." College English 4I (I979): I-I2.

Shaughnessy, Mina P. Errors and Expectations: A Guide for the Teacher of Basic Writing. New York: Oxford UP, 1977.

_. "The Miserable Truth." Maher 263-69. 


\section{Jessica Yood}

"But there is another sense in which the students we have been describing ought not to be viewed as transitional-as students, that is, whom colleges must sustain in a kind of holding action until the lower schools begin doing their jobs. They are, in some respects, a group from whom we have already learned much and from whom we can learn much more in the years ahead."

-Mina Shaughnessy, Errors and Expectations (29I, emphasis added)

"Someone who cares has to ask that question before the revolution can start. ... In the teaching of composition, the essential person who asked that question may not have been a man, but a woman, Mina Shaughnessy. ... Her example, her book, and her repeated calls for new research in composition have undoubtedly been important stimuli in spurring the profession's search for a new paradigm."

- Maxine Hairston, "The Winds of Change: Thomas Kuhn and the Revolution in the Teaching of Writing" (I2O, I2I)

Reading these two pioneers of the profession together forces us to consider the more well-known contribution of Shaughnessy alongside another kind of legacy: her radical critique of the aspirations of academia in general and the purpose of our profession in particular.

In her well-known 1982 article, "The Winds of Change: Thomas Kuhn and the Revolution in the Teaching of Writing," Maxine Hairston predicted, with much fanfare and dramatic prose, the birth of a new academic field-the modern discipline of Composition and Rhetoric. According to Hairston, it was Errors and Expectations that blew in these winds of change. The field, she claimed, was only poised towards disciplinarity, in a kind of purgatory (she called it the "transition phase") awaiting the revolution. In this piece, Hairston named Shaughnessy's "example, her book, her calls for research" as the "important stimuli" to move Composition from a "transitional phase" (I2O) of a paradigm shift into permanent disciplinary status.

Six stops on the Number 4 train from Yankee Stadium and around the corner from J-Lo's birthplace lies CUNY's Lehman College, a 37-acre tree-lined campus and the only four-year public college in this poorest of New York City's boroughs. On this patch of green in the Bronx come students from 90 countries-with more than half speaking English as a second language or dialect. Jessica Yood teaches at Lehman College. 
Lofty aspirations, indeed. And it's rather exciting to think about our work this way-geared toward greatness, ready for revolution, positioned to become, any day now, a profession with a paradigm. Shaughnessy's work would be that catalyst for radical change.

But with each of these promises we move a little farther away from Shaughnessy's premise about what we can find out from the less lofty goings on of basic writers in basic classrooms. She didn't want to transition to anywhere past the place where "errors and expectations" began: in her classroom. And so measuring that book-and everything associated with it - to the dimensions of paradigm is like trying to fit a round peg in a square hole. Or trying to put Yankee Stadium in Manhattan. It just doesn't fit.

This university-the City University of New York-and our profession-the teaching of writing, the scholarship of Composition and Rhetoric-have been through a great deal since the groundbreaking, disciplinedefining work of Maxine Hairston, and Mina Shaughnessy. We've had, and have, process and post-process and cultural studies and WAC and WID and basic writing and general education and service learning and so on. But taken together, with all of the good work these programs represent, I wonder: Where is the big idea? The paradigm?

I don't see one. Our initiatives are a little revolutionary and a little reactionary and, often, transitional. But not paradigmatic. The work of basic writing won't mesh with powerful paradigmatic promises. For every new program or new pedagogy we create, another is torn down, along with the politics and policies that often accompanied it. Many of us at CUNY, and elsewhere, came to Composition and basic writing because research wasn't enough. We wanted to search for-and find-meaning in teaching and being with students and their emerging ideas. We still want our work to last longer than an election cycle or a budget crisis.

And yet. Not transitional, not paradigmatic, our work today feels much like Shaughnessy described it thirty years ago: a rough draft we're still revising. We're not there yet, because our students and our teaching situations are constantly shifting. At times, this can feel unsettling. But for Shaughnessy, it wasn't. There was, she told us, great potential in constant motion. Paradigms declare and maintain. Composition continues to push farther, to suggest. This is, for me, the heart of Errors and Expectations. It argued that academia should be an opening: letting untraditional students in to the academy and letting willing and brave teachers and scholars out of the sometimes stifling confines of its abstractions and disciplinary demarcations. 
This, too, is a lofty aspiration, of another sort. But is it enough? Should we stop searching for that collective vision, the big idea, the paradigm of this generation's discipline? Might we, like Shaughnessy, find epistemological revolution elsewhere, rooted not in paradigms, but in persons, places, policies-in those areas of academia where the winds of change blow closer to the ground?

\section{Works Cited}

Hairston, Maxine. "The Winds of Change: Thomas Kuhn and the Revolution in the Teaching of Writing." Landmark Essays on Writing Process. Ed. Sondra Perl. Davis, CA: Hermagoras Press, I994. II3-26.

Shaughnessy, Mina P. Errors and Expectations. New York: Oxford UP, 1977.

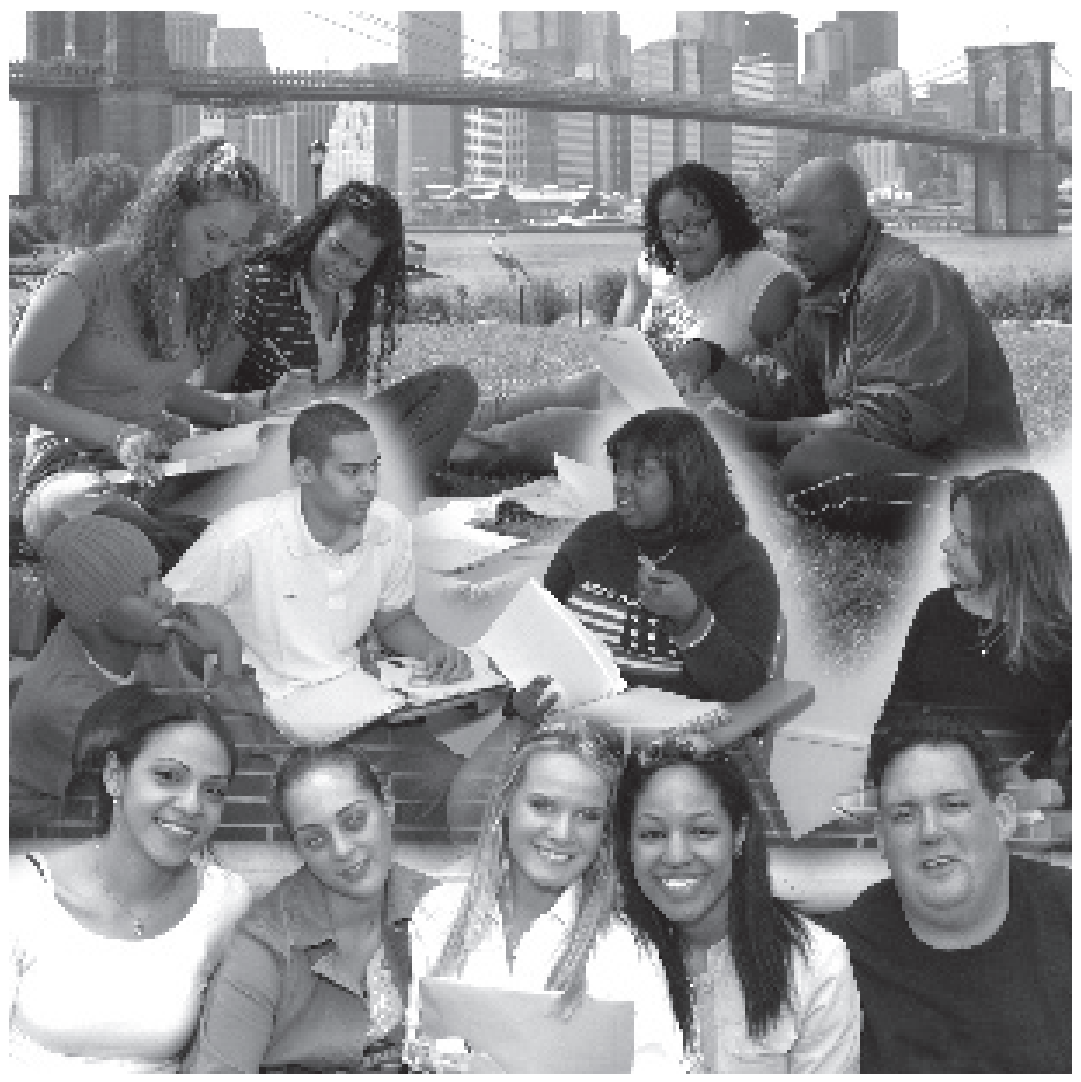

CUNY Students 2007 


\title{
Stretch at IO: A Progress Report on Arizona State University's Stretch Program
}

\author{
Gregory R. Glau
}

ABSTRACT: Arizona State University's basic writing Stretch Program has now been in existence for more than ten years. Statistical data for nearly 8, ooo Stretch Program students continues to indicate that the program helps a range of at-risk students succeed. This is true, also, for students from under-represented groups, who comprise roughly $40 \%$ of Stretch Program students. Stretch has been replicated at other colleges and universities, but as with any basic writing program, there are still problems and political issues that crop up and that must be dealt with .

KEYWORDS: Stretch Program, basic writing, under-represented groups, pass rate, continuation rate, retention

In the fall of I992, Arizona State University (ASU) had just completed several years during which its "basic writers" had been outsourced to a local community college. ${ }^{1}$ There had been the usual conversations about whether or not "basic writers" belonged at the university, and that perhaps the local community college would serve them better. But what Director of Composition David Schwalm had originally feared had come to pass: once these students were told to take a community college "remedial" writing class (ENG O7I), only a few of them ever returned to ASU to take other classes, and those who did were unprepared for the university-level work expected of them. The remedial classes (in which ASU controlled neither the curriculum nor the teachers nor the class size) simply did not serve these particular students well. In addition, students paid university tuition but received no college

Greg Glau is Director of Writing Programs at Arizona State University, Tempe, where he's taught since 1994. Before being appointed WPA, he directed ASU's basic writing Stretch Program. With Linda Adler-Kassner, Greg is past Co-Chair of the Conference on Basic Writing and co-editor of BWe: Basic Writing e-Journal. Greg is coauthor of Scenarios for Writing (Mayfield/McGraw-Hill, 20oI) and is currently working on Writing for College, Writing for Life with Duane Roen and Barry Maid (in press: McGraw-Hill, 20o8). Greg has published in WPA: Writing Program Administration, Rhetoric Review, English Journal, The Writing Instructor, IDEAS Plus, and Arizona English Bulletin. Greg regularly presents at CCCC and has presented at WPA, MLA, RMMLA, the Western States Composition Conference, NCTE, and others. Greg is immediate past co-editor for WPA: Writing Program Administration. For inquiries about the Stretch Program, e-mail the authoratgglau@asu.edu.

(C) Journal of Basic Writing, Vol. 26, No. 2, 2007 
credit for these outsourced classes. Schwalm was determined to somehow bring these basic writing students back to ASU and to do so in a way that would help them succeed and be retained at the university (for more about the issues and problems involved, see Schwalm).

Working with John Ramage, then Director of ASU's Writing Across the Curriculum program, Schwalm and Ramage together determined that what ASU's basic writing students needed more than anything else was more time: more time to think, more time to write, more time to revise. And they wanted to ask ASU's basic writers to do what Andrea Lunsford long ago suggested, to " ... continually be engaged in writing in a full rhetorical context, solving problems and practicing conceptual skills in a carefully sequenced set of assignments" (288).

Schwalm and Ramage designed two pilot programs, both intended to give students more time, and both requiring students to use the same textbooks and to work with the same assignments as did the students in "traditional" ENG Ior classes. The following academic year (I993/I994) ASU piloted two versions of classes for students identified as basic writers. One was called Jumbo - a six-semester-hour basic writing class. The results for Jumbo were mixed, and student response to the approach and their subsequent writing performance did not seem to be at the same level produced by the other approach. That other approach was labeled Stretch, a two-semester sequence designed to "stretch" ENG Ior over two semesters. Unfortunately, both the Jumbo and the Stretch pilots were pretty small, but the consensus was that Stretch helped students more, and, unlike Jumbo, clearly the Stretch model was faithful to Ramage and Schwalm's original notion that ASU's basic writers needed more time. So, beginning in the fall of I994, ASU's Stretch Program was initially launched, with 5I2 students enrolled. ${ }^{2}$

Both of these pilot programs attempted to do what David Bartholomae had suggested: to change the curriculum by first "chang[ing] the way the profession talked about the students who didn't fit" ("The Tidy House" 2I). Schwalm and Ramage in effect were arguing that the students accepted into ASU but placed into a basic writing class did not give "evidence of arrested cognitive development, arrested language development, or unruly or unpredictable language use" (Bartholomae, "Error" 254). Rather, they saw ASU's basic writing students as capable, and able to do the university-level writing the Department of English required. But they also believed that this subset of students could use more time and more directed writing experience, so they would not only write more but also receive more feedback and revision suggestions on their writing. Also, they wanted ASU to move away 
from an outsourcing approach and toward a mode of embracing those basic writers, to move from a view that these students are defective to one that, as Mina Shaughnessy taught us, understands that "students write the way they do, not because they are slow or non-verbal, indifferent to or incapable of academic excellence, but because they are beginners and must, like all beginners, learn by making mistakes" (5).

\section{Program Design ${ }^{3}$}

Since ASU's computer system would not allow Schwalm and Ramage to name the two-class Stretch sequence something like ENG IoIA and ENG IOIB, they decided to have the first class carry the Writing Across the Curriculum label as WAC IoI. So, even if the course was viewed as "remedial" (as so many basic writing programs are), this connection to the Writing Across the Curriculum program provided some political protection. ${ }^{4}$ Because the WAC Ior classes were to be directly connected to specifically-designated sections of ENG IOI, the Stretch sequence was created to be part of first-year composition, rather than something outside and thus vulnerable to political attack.

Schwalm and Ramage wanted to give ASU's beginning writers more time to work on and revise and think about their writing, so instead of doing all the ENG IOI assignments in one semester, they wrote three papers each semester, each with multiple drafts, along with a portfolio analysis of their writing, which served as a final examination. ${ }^{5}$ Just as it is important that Stretch students use the same textbooks that "traditional" ENG IoI students use, the direct connection between ENG IOI and Stretch assignments is critical.

To put this notion-that Stretch is a version of first-year composition-into a wider context, see Table I for the "tracks" students can take to fulfill their first-year writing requirement at ASU.

\section{Table I: Placement into ASU's Writing “Tracks"}

\author{
Stretch sequence \\ Traditional sequence \\ Accelerated sequence \\ ESL Stretch sequence \\ ESL traditional sequence
}

\author{
$\mathrm{WAC}$ IOI $\rightarrow$ ENG IOI $\rightarrow$ ENG IO2 \\ $\mathrm{ENG}$ IOI $\rightarrow$ ENG IO2 \\ ENG IO5 \\ WAC IO7 $\rightarrow$ ENG IO7 $\rightarrow$ ENG IO8 \\ ENG IO7 $\rightarrow$ ENG IO8
}


These several tracks are all seen (and represented to the administration and the public) as part and parcel of the same thing: the first-year writing requirement. What this new approach does is give our basic writing program protection from those who see such programs as remedial-if you want to attack Stretch, then you also have to attack the traditional version of ENG IOI, as well as the accelerated version of first-year writing (ENG IO5).

Contrast this model, where the basic writing program is part of the first-year writing program, uses the same books, asks students to construct the same assignments, etc., with one in which the basic writing program is seen as pre-English IoI. That view makes it easier for BW programs to be attacked as "not belonging at the university" and as "high school courses." Not so with Stretch.

Since Stretch classes are college-level classes, Stretch Program students earn three hours of elective credit for the first part of the Stretch course sequence (WAC IOI), credit that counts toward graduation at ASU, and then three hours of ENG IOI credit for their second semester's work (ENG IOI). The list that follows gives a few more administrative details that will be useful to anyone contemplating a Stretch model for their own college or university:

-WAC IOI/IO7 began as a pass/fail course, where the grades Stretch students earned for their papers and other work accumulated and counted as 50 percent of their ENG IOI grade. The original notion was that the pass/fail designation would take some of the pressure off of students during their first semester in college. However, students generally did not like the pass/fail aspect of WAC IOI/IO7, as the class then did not help their GPA. So, in 2007, WAC IOI/IO7 was changed to a graded class (largely because of those student concerns).

- ASU tries to keep the same teacher with the same group of students for both semesters. This doesn't always work out, of course, but it does most of the time, and Stretch students tell us that they very much like having the same classmates and the same teacher for two semesters. One thing we've noticed is that students who are together for two semesters generally build a useful "writing community." It takes some time for students to learn to trust each other in terms of peer feedback, and Stretch teachers almost always see, in that second semester, much improved peer review.

- Students place into all of ASU's writing classes based on their ACT or SAT scores. ${ }^{6}$ 
- ASU also offers sections of Stretch Program classes for international students, as these students especially benefit from more time to work on their writing.

- Stretch classes were initially capped at 22 students, as compared to 26 in traditional ENG IOI classrooms, so Stretch students would receive more personal attention. Beginning in the fall of 2004 , all Ioo-level English classes were capped at $19 .{ }^{7}$

\section{Long-Term Results}

Not all of our data paints Stretch in a perfect light; frankly, there are areas we need to improve on. At the same time, however, most of the data indicates that the Stretch concept actually works and that thousands of students have benefited from the extra time and guided writing experience they receive with the WAC IOI-ENG IOI Stretch sequence.

To track accurately what happens with Stretch students, we use a stepmodel $:^{8}$

A number of students register for WAC IOI

A percentage of these students pass WAC IOI

A percentage of these students register for ENG IOI

A percentage of these students pass ENG IOI

A percentage of these students register for ENG IO2

A percentage of these students pas ENG IO2

There are a number of ways to consider this data, and for our purposes here we will provide information on:

\section{Student Profile}

- Stretch student ACT/SAT scores compared to traditional ENG IOI students.

- Enrollment by students from historically under-represented groups (at ASU, we consider these to be students who self-identify as African American, Asian American, Hispanic, or Native American students). ${ }^{9}$

\section{Pass Rates}

- For WAC IoI compared to pass rates for the previous communitycollege class (ENG O7I). 
- For Stretch ENG Ior students compared to pass rates for students taking traditional ENG IoI.

- For Stretch students once they're done with Stretch and take ENG IO2, compared to traditional ENG IO2 students.

- For students from historically under-represented groups.

Continuation Rates

- Fall-spring retention (for Stretch students, that is from WAC Io I to ENG IOI; for traditional students, it's from ENG IOI to ENG IO2).

The step model, then, will examine:

A number of students register for WAC IOI [student profile] A percentage of these students pass WAC IoI [pass rates] A percentage of these students register for ENG IOI [continuation rate]

A percentage of these students pass ENG IOI [pass rates] A percentage of these students register for ENG IO2 [continuation rate]

A percentage of these students pass ENG IO2 [pass rate]

We have-after a full ten years of Stretch's existence and because ASU is such a large institution-some pretty large data sets. To provide a sense of the numbers we will detail below, here are a few statistics from those data sets:

- Number of WAC IOI students, fall semesters I994 through 2004: 7,826

- Number of ENG IOI students, academic years I994-95 through 2004-05: 45,668

- Number of WAC IoI students from under-represented groups, fall I994 through fall 2004: 2, 856

- Number of ENG IOI students from under-represented groups, academic years I994-95 through 2004-05: 9, 873

- Number of ENG IO2 students, academic years I994-95 through 2004-05: 53, 5I6

- Number of ENG IO2 students from under-represented groups, academic years I994-95 through 2004-05: IO, 53I 


\section{Who Our Students Are}

Arizona State University is a large, urban university with roughly 50,00o students on the Tempe campus. There are now versions of Stretch at the other three ASU campuses, but their data is so new that it is not included here.

As noted above, we place all of our students-roughly 9, ooo in our firstyear classes - into either Stretch, traditional ENG IOI, or ENG IO5 based on their standardized test scores. While from time to time we have conversations on whether we might somehow move to a form of directed self-placement (see Royer and Gillis, "Directed" and “Basic Writing”), we haven't yet figured out how to do this with so many new students each fall semester. To make matters worse, ASU (as of this writing) does not have mandatory orientation, so we wouldn't be able to provide placement information and advice to all incoming students. So for now we're continuing to place students based on their SAT verbal or ACT English scores (this appeals to the university administration since the students pay for this testing). At the same time, there do seem to be significant differences in the average scores of Stretch students, as compared to those placed into ENG IOI. The following data is from fall semesters, as that's when most of our students start their classes here. For the II fall semesters (since Stretch was put into place: fall I994-fall 2004): ${ }^{10}$

- 5,362 WAC Ior students had an SAT verbal score, averaging 425.

- 28,II3 ENG Ior students had an SAT verbal score, averaging 544.

On average, then, the SAT verbal score for Stretch students is about I2O points lower than their counterparts who place in traditional ENG IOI classes. (There is roughly the same difference- $\mathrm{I} 2 \mathrm{O}$ points-between students placed into ENG IOI and those placed into ENG I05, our one-semester class that fulfills the composition requirement.) The same is true for ACT scores:

- 4,408 WAC Ior students had an ACT English score, averaging I6.

- 20,I85 ENG IoI students had an ACT English score, averaging 23.

In addition, more Stretch students—by a large margin-are identified as belonging to an historically under-represented group (at ASU, we consider 
these to be students who self-identify as African American, Asian American, Hispanic, or Native American). Students from these populations-since the majority of them, historically, have not attended college-are sometimes seen as at-risk in terms of university success (and since twice as many place into our basic writing sequence of classes, they also are seen as at-risk based on their test scores):

- Over the io fall semesters (1994-2004), $\mathbf{3 6 . 4 9 \%}$ of the students registered in WAC IoI were from these under-represented groups.

- Over the past Io academic years (I995-96-2004-2005), 2I.62\% of the students registered in traditional ENG IoI were from these under-represented groups.

ASU has made great progress at including more students from underrepresented groups: in the fall of $1995, \mathbf{1 8 . 7 \%}$ of our new students came from under-represented groups. By the fall of 2006, however, some $\mathbf{2 5 . 6 \%}$ came from those groups. At the same time, Stretch's population was also changing: in the fall of $2006, \mathbf{4 3 . 2 \%}$ of WAC IOI students came from those under-represented groups.

In effect, then, while traditional ENG IOI classes have about one student in five or so from one of these under-represented groups, Stretch classes have almost twice that number-almost two in five. This data reflects, of course, any cultural bias in standardized testing, in addition to how effectively (or ineffectively) a student's grammar-, middle-, and high-school education has prepared that student for the ACT or SAT. In Arizona such preparation is often worse than in other states, as our continually conservative state legislature constantly refuses-even under court order-to properly fund schools in poorer Arizona communities.

In any case, that's a snapshot of Stretch students: they're seen as the most at-risk because they have the worst test scores (by a significant degree), and more of them come from groups that historically have not attended universities.

\section{How Our Students Perform}

One way to measure how Stretch students perform is to consider how they do in comparison to other groups of students. You may recall that WAC IOI replaced the community college ENG O7I class. For the final five years 
(before we implemented Stretch) we asked our basic writing students to take ENG 07I, the pass rate was $\mathbf{6 6 . 2 2 \%}$. In comparison, students pass WAC Ior at a $\mathbf{9 0 . 1 5 \%}$ rate. This pass rate-reflecting student success-is significant because when many students fail a class, they simply stop coming to school. So when ASU implemented Stretch, our retention rate immediately improved.

While our basic writing students clearly did better in WAC IOI than in the class they had been taking, ENG 07I, how did they fare against their ENG IOI counterparts? To properly compare the two sets of students, we need to compare how both groups did when taking ENG IOI (this data covers academic years I994-I995 through 2004-2005):

- The pass rate for Stretch ENG IoI students averages $92.65 \%$.

- The pass rate for traditional ENG IoI students averages $\mathbf{8 8 . 8 8 \%}$.

Clearly, the WAC Ior semester, which gives these at-risk students more guided writing experience, helps them. Stretch Program students consistently pass ENG IOI at a higher rate than do their counterparts who take traditional ENG Iог. ${ }^{11}$ Incidentally, these pass rates hold true over time (see Figure I).

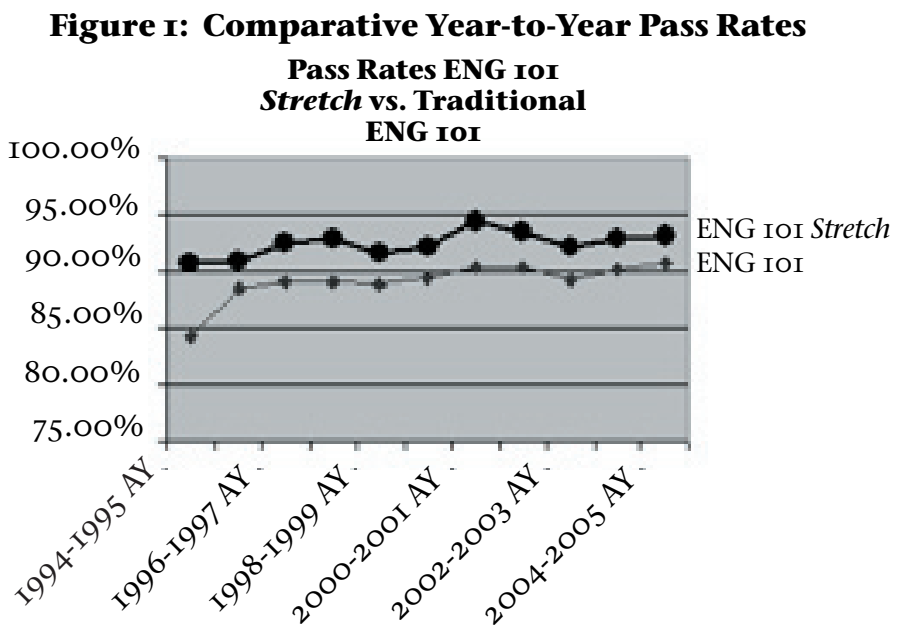

How do Stretch students perform when they leave the program and take ENG IO2? Again, Stretch students consistently pass ENG IO2 at a higher rate than do their traditional ENG IOI counterparts (see Figure 2). 
Figure 2: Comparative Pass Rates for Stretch ENG Ior and Traditional ENG IOI

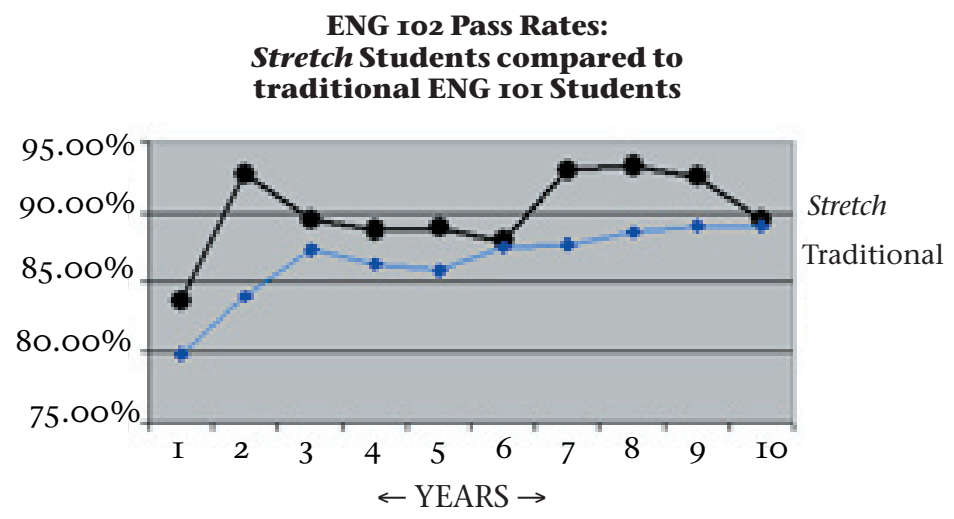

We see similar data sets-a higher pass rate-for students from historically under-represented groups. These students pass ENG IOI at a higher rate when they're in the Stretch Program (as above, this data covers academic years I994-95 through 2004-05):

- Students from under-represented groups pass Stretch ENG Ior at an average rate of $\mathbf{9 0 . 8 I} \%$.

- Students from under-represented groups pass traditional ENG IOI at an average rate of $\mathbf{8 7 . 3 4 \%}$.

As with students in our general student population, the data for students from under-represented groups also holds true over time. They consistently pass ENG IOI at a higher rate than do those students in traditional ENG IoI classes: 


\title{
Figure 3: Comparative Year-to-Year Pass Rates for Students from Under-Represented Groups in ENG IoI
}

\author{
Pass Rates ENG IoI Stretch \\ vs. traditional ENG IoI, students \\ from under-reprensented groups
}

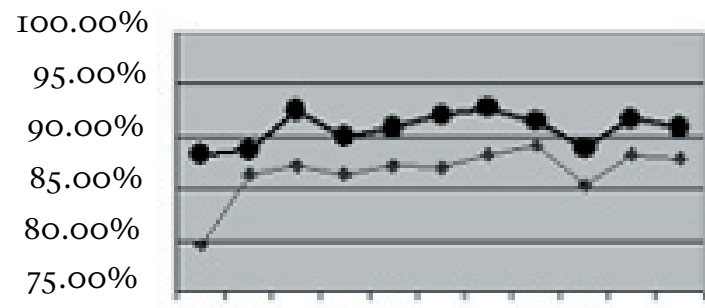

ENG IOI Stretch

ENG IOI

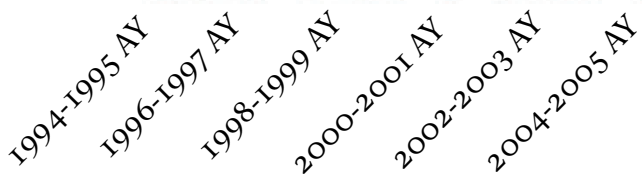

For both our general group of students, then, as well as students from under-represented groups, the extra semester of guided writing experience enhances their success in ENG IOI. But it's important to note that we're not quite comparing apples-to-apples here. That is, the Stretch Program students we're examining have already taken and passed WAC IoI, usually with the same teacher and group of students-so even with the lower test scores and even though more come from under-represented groups and are seen as atrisk in the university ... perhaps they should pass ENG IOI at a higher rate, since as part of the Stretch Program they have more time to spend on their writing, and are with the teacher for two semesters.

So how do Stretch students do when they move to the next semester and take ENG IO2? Former Stretch students from under-represented groups-the ones with the worst test scores - appear to benefit from the extra semester of guided writing experience: they pass ENG IO2 at a higher rate than do traditional ENG IO2 students (this data covers academic years I994-95 through 2004-05):

- Stretch students from under represented groups pass ENG IO2 at an average rate of $\mathbf{8 8 . 6 5 \%}$.

- Students from under represented groups taking traditional ENG IOI pass ENG IO2 at an average rate of $\mathbf{8 4 . 1 7 \%}$ 
As with data for our general student population, these pass rates are as outlined in Figure 4. While recently the comparative pass rates have been getting closer, students who had the benefit of taking WAC Ior clearly benefit-in terms of passing-when they do take ENG IO2.

\title{
Figure 4: Comparative Year-to-Year Pass Rates for Students from Under-Represented Groups in ENG 102
}

\author{
Pass Rates Stretch students taking \\ ENG Io2 vs. traditional Io2 students \\ (all students from under-represented groups)
}

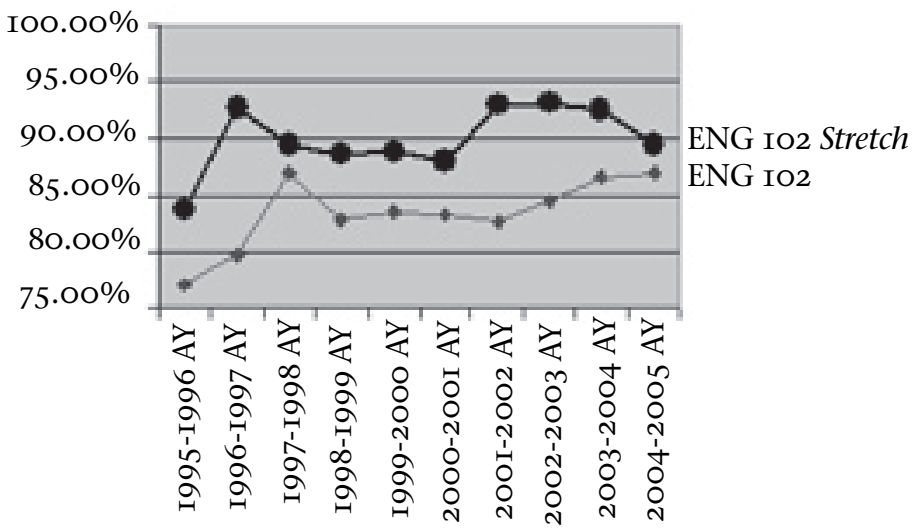

It's important to note that Stretch doesn't seem to help one group of students as well as it helps others. That is, when we compare how, say, Asian American students succeed in ENG IOI as compared to WAC IOI, we don't see much difference. While Asian American students pass ENG IOI at a 90.97 $\%$ rate, their passing rate for WAC Ior is only slightly lower, $89.50 \%$. But for our Native American students, the results are somewhat starker. Native American students pass ENG IOI at a rate of $86.22 \%$; they pass WAC IOI at a rate of $8 \mathrm{I} .68 \%$. In effect, about five percent more of our Native American students fail WAC IOI than fail ENG IOI.

The other two groups of students from under-represented groups (Hispanic and African American) pass both ENG IOI and WAC IoI within two percentage points of each other. The only big difference is the poor pass rate of Native American students in our WAC Ior classes, and at this point we do not have an answer as to why. 


\section{How Stretch Program Students Persist}

Finally, how do Stretch students persist? One way to consider student persistence is to look at, for example, the percentage of students who pass ENG IOI in the fall semester and subsequently register for ENG IO2 the following semester. Likewise, we can track Stretch students who took WAC IOI in the fall and then registered to take ENG Ior the following semester. ${ }^{12}$ The cumulative percentages are:

- 90.90\% of Stretch students who pass WAC Ior in the fall take ENG IOI the next spring.

- $\mathbf{8 6 . 5 2} \%$ of traditional students who pass ENG IOI in the fall take ENG IO2 the next spring.

Figure 5 shows student continuation data from fall I994/spring 1995 to the fall of 2004/spring 2005, demonstrating that during each fall-spring period, Stretch students continued to the next class at a somewhat higher rate than their traditional counterparts.

\section{Figure 5: Comparative Continuation Rates for Stretch and Traditional Students in ENG Ior \& ENG 102}

\section{Continuation Rates: \\ Passed WAC Ior fall \& took ENG IoI the next spring Passed ENG IoI fall \& took ENG Ior the next spring}

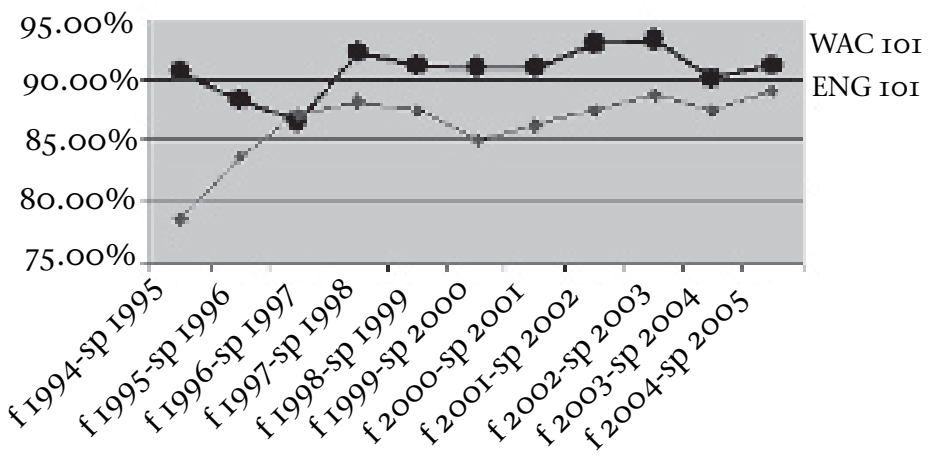


From a more qualitative point of view, Stretch students indicate that they feel the sequence improved their writing (about 90\% say so). What they like most about the program is having more time to work on their writing, which validates Schwalm and Ramage's initial concept. Students also like being able to work with the same group of students and have the same teacher for both the WAC and ENG portions of the program.

\section{Where Do We Go From Here?}

The most recent modification to Stretch, as noted earlier, was to change the first class in the Stretch sequence from pass/fail to graded.

We continue to monitor the program, especially in light of the fall 2004 modification that dropped the cap on all Ioo-level English classes to I9 students. One area we're all concerned with is retention, usually measured by the number of first-time full-time freshmen who take classes one fall and then return the subsequent fall. As of this writing, we have two full years of data (2004-2005, and 2005-2006) and can say that "retention" rates for students taking WAC IOI, ENG IOI, ENG IO2, and ENG IO5 are all higher than they were when class sizes were larger. I'd hesitate to give all of the credit for student retention to the smaller class size, but it only makes sense that smaller classes help everything else the university is doing to aid retention.

We also have an eye on what our sister institution, the University of Arizona, is doing to help their basic writers. For the past two years the $\mathrm{U}$ of A has offered what they call ENG IOI+, essentially a writing studio model in which students classified as basic writers are required to attend an additional one-hour session along with their writing class. These sessions are facilitated by the regular $\mathrm{U}$ of $\mathrm{A}$ writing teachers, and their preliminary results are very promising.

Is Stretch the correct model for every institution? Of course not: it works very well at ASU, and has for more than ten years now, and we expect it to continue to serve our basic writing student population. At the same time, we're cognizant of how other colleges and universities help their own basic writers and we'll continue to monitor and modify Stretch as time goes on.

\section{A Postscript}

In 2003, Stretch won ASU's President's Award for Innovation. My thought at the time was that such an award would give Stretch some political 
protection. After all, how could anyone attack a program that was not only a national model but that also won our own President's award?

Alas, in August of 2007 (as I'm writing this), our new Dean, under enrollment pressure, raised the caps of half of our WAC IoI sections from ig to 22 (they must have felt they needed about Ioo extra WAC IoI seats, as they raised the caps on 34 WAC IOI sections by three students in each section).

The Dean did so over my objections as well as the strong objections of the Chair of the Department of English. The Dean's decision to raise the caps was made on the Friday before classes started, at 4:45 in the afternoon.

Since then, we've met with the Dean and shared with him the kinds of information on success rates, ethnic mix, and so on that we've reported in this article. The Dean was apologetic; he seemed to understand the student population involved; he seemed to realize that, under enrollment pressure, he'd made an unfortunate decision; he spoke of more resources for us "now that I've seen this information." Time will tell, of course, so stay tuned, as what seemed to be a lemon on the Friday before classes began might yet turn into lemonade. At least with our basic writing program, there's never a dull moment!

\section{Notes}

I. For a discussion on the problematic terms "basic writer" and "basic writing," see Adler-Kassner; DeGenaro and White; Rosendale Rethinking and "Investigating"; Rosen-Knill and Lynch; Shaughnessy (40).

2. There are, of course, other approaches designed to help students identified as basic writers. See, for example, Crouch and McNenney; Fitzgerald "The Context" and "Basic Writing;" Goen and Gillotte-Tropp; Gleason; Grego and Thompson; Lalicker; Smoke; Soliday and Gleason; Winslow and Mische; Wiley.

3. For more details on the overall Stretch Program design, see Glau, "The Stretch Program," "Mainstream Plus," and "Bringing Them Home"; also see Lalicker.

4. For more on why basic writing programs often need "political protection," see Adler-Kassner and Harrington; Collins and Blum; Gilyard; Goto; Harrington and Adler-Kassner; Mutnick; Rodby and Fox; Soliday; Stevens.

5. When Stretch started, ENG Ior students wrote six papers, so it made logical sense for WAC Ior students to write three papers, followed by three more in their ENG IoI semester. Today (2007), traditional ENG Ior students write four papers over the course of a semester, so now Stretch students are both stretched 
(more time) and expanded (they write six vs. four papers in traditional ENG IOI classes) in terms of the work they do for their writing classes.

6. Students with an SAT verbal score of 530 or lower, or an ACT Enhanced English score of I8 or lower are placed into the Stretch Program. Students with a TOEFL score of 540 or less are placed in the ESL version of the Stretch Program. Students with a 620 or higher on the SAT verbal or 26 or higher on the SAT English can take our one-semester class, ENG I05. For a more comprehensive look at placement, see White.

7. As of this writing we have three full years worth of data with these smaller class sizes. Since we dropped the class size to I9, pass rates are higher for WAC IOI and ENG IOI and IO2 than they've historically averaged; DWE (drop-withdraw-failure) rates are lower, continuation from fall to spring is better, and student evaluation numbers are all better than they have been, historically, for all ranges of teachers (Professors, Lecturers, Instructors, Teaching Assistants, and Faculty Associates).

8. For a long-term look at basic writers using a longitudinal case study approach, see Sternglass.

9. Eleanor Andrew and Margaret McLaughlin provide a useful discussion that focuses on African American BW students; Laura Gray-Rosendale, Loyola K. Bird, and Judith F. Bullock provide a thoughtful discussion of Native American student experience in BW and other classes. For a useful discussion of how we teachers represent race in our own research and writing, see Center.

Io. Some students, of course, had both an ACT and SAT score, so there is some overlap in student populations for these score groups.

II. Students exit from the Stretch Program based on the teacher's judgment of progress, which is in turn based on the Writing Program's goals and objectives as articulated in our version of the WPA Outcomes Statement.

I2. Of course, some students who pass WAC IOI or ENG IOI in the fall simply don't take an ENG class the following spring semester. Our thinking is that the small percentage of such students is probably about the same for both groups we're considering here, so the results, as shown, are probably pretty accurate. 


\section{Works Cited}

Adler-Kassner, Linda. "Just Writing, Basically: Basic Writers on Basic Writing." Journal of Basic Writing I8.2 (I999): 69-90.

Adler-Kassner, Linda, and Susanmarie Harrington. Basic Writing as a Political Act: Public Conversations about Writing and Literacy. Creskill, NJ: Hampton, 2002.

Agnew, Eleanor, and Margaret McLaughlin. "Those Crazy Gates and How They Swing: Tracking the System that Tracks African-American Students." Mainstreaming Basic Writing. Ed. Gerri McNenny. Mahwah, NJ: Erlbaum, 200I. 85-Ioo.

Bartholomae, David. "The Study of Error." College Composition and Communication 3I.3 (I980): 253-69.

_. " The Tidy House: Basic Writing in the American Curriculum." Journal of Basic Writing I2.I (I993): 4-2I.

Center, Carole. "Representing Race in Basic Writing Scholarship." Journal of Basic Writing 26.I (2007): 20-42.

Collins, Terrence, and Melissa Blum. "Meanness and Failure: Sanctioning Basic Writers." Journal of Basic Writing I9.I (2000): I3-2I.

Crouch, Mary Kay, and Gerri McNenney. "Looking Back, Looking Forward: California Grapples with 'Remediation." Journal of Basic Writing I9.2 (2000): 44-7I.

DeGenaro, William, and Edward M. White. "Going Around in Circles: Methodological Issues in Basic Writing Research." Journal of Basic Writing I9.I (2000): 22-35.

Fitzgerald, Sallyanne H. "The Context Determines Our Choice: Curriculum, Students, and Faculty." Mainstreaming Basic Writing. Ed. Gerri McNenny. Mahwah, NJ: Erlbaum, 200I. 215-23.

_. "Basic Writing in One California Community College." BWe: Basic Writing e-Journal I.2 (I999). < http://www.asu.edu/clas/english/composition/cbw/bwe_fall_I999.htm $>$.

Gilyard, Keith. "Basic Writing, Cost Effectiveness, and Ideology." Journal of Basic Writing I9.I (2000): 36-42.

Glau, Gregory R.. "Bringing Them Home: Three perspectives of the Stretch Program-A New Model of University-Level Basic Writing Instruction." I996 CCCC Conference. Milwaukee, March I996. Published as ERIC document ED 403 558, I997.

_. "Mainstream Plus: Basic Writing Programs that Work." I998 CCCC Conference. Chicago, April I998. Published as ERIC document ED 
4I9 237, I999.

“The Stretch Program: Arizona State University's New Model of Universitylevel Basic Writing Instruction." WPA: Writing Program Administration 2O.I-2 (I996): 79-9I.

Gleason, Barbara. "Returning Adults to the Mainstream: Toward a Curriculum of Diverse Student Writers." Mainstreaming Basic Writing. Ed. Gerri McNenny. Mahwah, NJ: Erlbaum, 2OoI. I2I-43.

Goen, Sugie, and Helen Gillotte-Tropp. "Integrating Reading and Writing: A Response to the Basic Writing 'Crisis." Journal of Basic Writing 22.2 (2003): 9O-II3.

Goto, Stanford T. "Basic Writers and Policy Reform: Why We Keep Talking Past Each Other." Journal of Basic Writing 2I.2 (2OOI): I-2O.

Gray-Rosendale, Laura. "Investigating Our Discursive History: JBW and the Construction of the 'Basic Writer's' Identity." Journal of Basic Writing I8.2 (I999): IO8-35.

. Rethinking Basic Writing. Mahwah, NJ: Erlbaum, 2000.

Gray-Rosendale, Laura, Loyola K. Bird, and Judith F. Bullock. "Rethinking the Basic Writing Frontier: Native American Students' Challenge to Our Histories." Journal of Basic Writing 22.I (2003): 7I-IO6.

Grego, Rhonda, and Nancy Thompson. "Repositioning Remediation: Renegotiating Composition's Work in the Academy." College Composition and Communication 47.I (I996): 62-84.

Lalicker, William B. "A Basic Introduction to Basic Writing Program Structures: A Baseline and Five Alternatives." BWe: Basic Writing e-Journal I.2 (I999). <http://www.asu.edu/clas/english/composition/cbw/bwe_ fall_I999.htm\#bill >.

Lunsford, Andrea A. “The Content of Basic Writers' Essays.” College Composition and Communication 3I.3 (I980): 278-90.

Mutnick, Deborah. "The Strategic Value of Basic Writing: An Analysis of the Current Moment." Journal of Basic Writing I9.I (2000): 69-83.

Rodby, Judith, and Tom Fox. "Basic Work and Material Acts: The Ironies, Discrepancies, and Disjunctures of Basic Writing and Mainstreaming." Journal of Basic Writing I9.I (2000): 84-99.

Rosen-Knill, Deborah, and Kim Lynch. "A Method for Describing Basic Writers and Their Writing: Lessons from a Case Study." Journal of Basic Writing I9.2 (2000): 93-II7.

Royer, Daniel J., and Roger Gilles. "Basic Writing and Directed Self-Placement." BWe: Basic Writing e-Journal 2.2 (2000). <http://www.asu.edu/ clas/english/composition/cbw/summer_2Ooo_V2N2.htm $>$. 
. Directed Self-Placement: Principles and Practices. Creskill, NJ: Hampton, 2003.

Schwalm, David E. "Teaching Basic Writing: The Community College on the University Campus." WPA: Writing Program Administration I3.I-2 (I989): I5-24.

Shaughnessey, Mina P. Errors and Expectations: A Guide for the Teacher of Basic Writing. New York: Oxford UP I977.

Sheridan-Rabideau, Mary P., and Gordon Brossell. "Finding Basic Writing's Place." Journal of Basic Writing I4.I (I995): 2I-26.

Smoke, Trudy. "Mainstreaming Writing: What Does This Mean for ESL Students?" Mainstreaming Basic Writing. Ed. Gerri McNenny. Mahwah, NJ: Erlbaum, 200I. I93-2I4.

Soliday, Mary. The Politics of Remediation: Institutional and Student Needs in Higher Education. Pittsburgh: University of Pittsburgh P, 2002.

Soliday, Mary, and Barbara Gleason. "From Remediation to Enrichment: Evaluating a Mainstreaming Project." Journal of Basic Writing I6.I (I997): 64-78.

Sternglass, Marilyn S. Time to Know Them. Mahwah, NJ: Erlbaum, I997.

Stevens, Scott. "Nowhere to Go: Basic Writing and the Scapegoating of Civic Failure." Journal of Basic Writing 2I.I (2002): 3-I5.

White, Edward M. "Revisiting the Importance of Placement and Basic Studies: Evidence of Success." Mainstreaming Basic Writing. Ed. Gerri McNenny. Mahwah, NJ: Erlbaum, 200I. I9-28.

Wiley, Mark. "Mainstreaming and Other Experiments in a Learning Community." Mainstreaming Basic Writing. Ed. Gerri McNenny. Mahwah, NJ: Erlbaum, 200I. I73-9I.

Winslow, Rosemary, and Monica Mische. "Rethinking At-Risk Students' Knowledge and Needs: Heroes' Decisions and Students' Quest for Identity and Meaning in a Content Composition Course." Mainstreaming Basic Writing. Ed. Gerri McNenny. Mahwah, NJ: Erlbaum, 20oI. I45-7I. 


\title{
Re-Modeling Basic Writing
}

\author{
Rachel Rigolino and Penny Freel
}

\begin{abstract}
In 1996, the State University of New York at New Paltz developed the Supplemental Writing Workshop Program for its basic writing students in response to public pressure to discontinue the offering of so-called remedial writing courses at four-year institutions. Our primary purpose in this article is to describe the design of the SWW Program, which we envision as a Seamless Supportmodel of instruction. In this model, basic writing students receive extra support in the form of integrated writing workshop and tutoring sessions. SWW sections of composition have the same objectives and requirements as non-SWW sections and award the same credit, enabling basic writers to progress towards completion of the Composition I and Composition II sequence in two semesters. Now in its eleventh year, the SWW Program has proven to be successful in terms of the way its students compare with their cohorts in the areas of retention and graduation rates, and overall GPAs. While further research, including more thorough qualitative analysis, needs to be done, it is our hope that the success of this model can be used to inform the ongoing conversations about the future of basic writing in the academy.
\end{abstract}

KEYWORDS: basic writing; writing instruction; higher education; remedial instruction college instruction; program description

In their 2006 article, "In the Here and Now: Public Policy and Basic Writing," Linda Adler-Kassner and Susanmarie Harrington warn that the public discourse about basic writing programs and their role in the academy is increasingly being shaped by constituents outside of composition classrooms. As a result, writing program administrators (WPAs) often find themselves reacting to edicts from policy makers instead of informing policy; and, as Bruce Horner points out, modifications to the curricular designs of many basic writing programs are often "implemented in hurried response to circumstances not chosen by either composition teachers or their students but others-deans and provosts, political appointees, [and] state legislators" (I34). Indeed the success of the various permutations of basic writing models that have evolved since the mid-I99os is a testament to the commitment of basic writing faculty and administrators, to basic writing scholarship and research, and to the students who seem perennially to be at risk of being shut out of the academy.

Rachel Rigolino is the Coordinator of the SWW Composition Program at SUNY New Paltz. She also teaches writing for the Black Studies Department as well as lower-division literature courses. Penny Freel is a Lecturer in English at SUNY New Paltz, where she teaches ESL composition. She has also taught at the University of the Sacred Heart in Tokyo, Japan.

(C) Journal of Basic Writing, Vol. 26, No. 2, 2007 
By 1999, William B. Lalicker, who had conducted a national survey of WPAs, could identify five alternatives to the increasingly maligned noncredit baseline model of basic writing. Because students are placed into basic writing classes largely on the basis of how well they perform on standardized exams and/or timed writing samples, one approach to reconfiguring basic writing programs is to amend placement procedures. Under the self-directed placement model, students place themselves into non-credit bearing sections of basic writing; while yet another approach is to eliminate the designation of basic writers altogether, as City University of New York (CUNY) has done at their senior, four-year colleges, effectively mainstreaming students. (It should be noted, however, that although Lalicker describes CUNY's as a mainstreaming model, the reality, at present, is more complex. Students who do not score above 480 on the SAT verbal or do not pass the CUNY/ ACT placement exams in reading, writing, and math are excluded from the senior colleges-a mechanism that came about, as will be discussed later, in a heated political climate.) While the self-placement model and the mainstream model approach placement and course design in two very different ways, they both resist the labeling of students by the institution. In the first model, it is the student, not the university, who assesses the student's level of proficiency. In the second model, the composition program declines to identify any accepted student as a remedial writer so there is no longer a label to affix.

Another approach to redesigning basic writing courses centers on finding ways to provide students with additional time as they work towards fulfilling first-year writing requirements. The stretch approach, first implemented at Arizona State University, provides students an extra semester to complete ENG IOI. At the end of the second semester, students at ASU earn credit for ENG IOI as well as three elective credits. The studio model, pioneered by Rhonda Grego and Nancy Thompson at the University of South Carolina, provides an additional hour of workshop time outside of class to mainstreamed basic writers. Instead of "stretching out" a one-semester, credit-bearing course into two or more semesters, the studio model provides students with additional time each week to strengthen their writing. While the amount and type of credit awarded for participating in stretch and studio programs vary, both models address an inherent inequity in the baseline model through reconfiguring courses so that they award academic credit (see Glau, "Stretch at Io: A Progress Report on Arizona State University's Stretch Program," this issue; Grego and Thompson). 
All of these models seek, in one way or another, to eliminate the stigma attached to the labeling of students as "remedial" as well as to address the problems associated with granting some students credit for writing courses while denying credit (and advancement towards degree) to others. That these models have been successfully implemented is beyond dispute, as anyone conducting a review of the literature can attest. Still, if we are searching for a way to "reframe the concept of remediation" (28), a task Adler-Kassner and Harrington call upon teachers of basic writing to undertake, we must do more than rethink how we place students on the one hand and how we award academic credit on the other. The self-directed and mainstream models, for example, do not directly address issues of curricular design; and the stretch model, while redesigning basic writing courses so that they share the same course objectives as non-basic writing courses, requires that students spend more time working towards a degree, a residual problem of all baseline models.

The intent of this paper is to offer up for critique a fifth model of basic writing program design, one which, we posit, attempts a more thorough re-modeling of the traditional remedial approach. The Supplemental Writing Workshop Program at the State University of New York at New Paltz is an example of what Lalicker calls an "intensive" model. As with the studio model, the intensive model provides students an additional hour of workshop time. What differentiates the intensive from the studio model is that the workshop hour is integrated into the rest of the course. All the students in a particular class section attend the same workshop session, which is often taught by the course instructor. While it was this model which we used as a template when redesigning our basic writing program at the State University of New York at New Paltz in I995, instead of the word "intensive," faculty and administrators in the SWW Program have used the term "seamless support" to describe our program model since its inception. Disputes over jargon are seldom enlightening, yet examining our long-standing use of seamless support is, we feel, worth a brief digression.

From the outset, the concept of providing seamless support grew out of a desire not only to provide students with extra time, but also to weave together specific resources into a cohesive course design. We wanted to incorporate both individual tutoring as well as workshop sessions into our program in such a way that these elements, while distinct from time spent in the classroom, were part of a holistic pedagogical approach. Unlike Grego and Thompson's original studio design, in which students from various sections of composition come together once a week to work with an outside 
instructor, the Seamless Support Program keeps students, instructors, and in-class tutors together. The chart below illustrates how the course is structured, focusing on who participates in which areas:

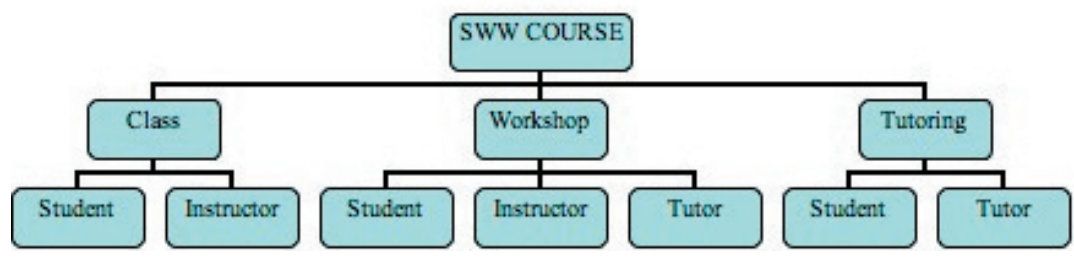

Not only are classroom instruction, workshop time, and individual tutoring all integral parts of the course design, the roles of the instructor and tutor overlap in areas that have been proven critical to student success, as will be discussed later in this paper.

Moreover, it is important to note that the SWW Seamless Support model is not "remedial" in its design. In other words, students enrolled in the program are expected to complete the same assignments and readings as their cohorts in non-SWW composition courses. All of our composition courses share the same objectives and aims; have the same course numbers: ENG I6o (Composition I) and ENG I80 (Composition II); and award the same amount of academic credit. How the SWW Program differs is in the amount of support the students receive: students spend one (or two, in the case of ESL students) additional class hour(s) in a workshop and another hour working one-on-one with an experienced tutor. While these hours are not awarded academic credit - an aspect of the program with which many of the SWW faculty members are not comfortable-they are integral components of the course, not merely contact hours that have been added on. As we will demonstrate, this model, which has proven versatile enough to serve the needs of both native and non-native speakers of English, provides students with the support and time they need to complete their composition requirements in the same two-semester sequence as their cohorts.

\section{Background}

The SWW Program, like so many other innovative basic writing programs, grew out of a re-assessment of traditional basic writing courses which began in the mid-I99os when calls for eliminating what were known as remedial classes at four-year colleges became increasingly insistent. The 
National Center for Educational Statistics reported in I995 that almost 30\% of first-year college students were enrolled in at least one remedial course; and stakeholders both within and outside the academy were becoming more vocal in their criticism of this state of affairs. A June I995 article in the New York Times noted that “with today's atmosphere of budget-balancing and cost-cutting, more people are raising questions about whether remedial education belongs in the four-year college setting" (Knowlton BII).

Basic writing courses were the focus of much of the criticism, and many writing program administrators around the country found themselves scrambling to reconfigure their course offerings in anticipation of imposed curricular changes. During the I990s, perhaps the most well-known battles over the place of basic writers in the academy occurred during what Bart Meyers, a professor of psychology at Brooklyn College, aptly named the "CUNY Wars." Critics were making headlines in the New York press with their calls for reform of the CUNY system where, it was asserted, "remediation has cheapened the CUNY degree, and dumb[ed] down . . college classes" (Berman, qtd. by CUNY Community College Conference). At the same time, both Governor George Pataki and Mayor Rudolph Giuliani were threatening to slash the CUNY budget, raise tuition, and eliminate EOP (Educational Opportunity Program) and SEEK (Search for Education, Elevation, and Knowledge), programs which typically serve educationally underprepared students. In May I998, the CUNY Board of Trustees, many of whom had been appointed by Pataki and Giuliani, responded by putting an end to remediation at the four-year colleges, a move which the head of the University Faculty Senate noted was made "without considering the human and financial consequences," and promised "not to reform but to destroy the university" (Cooper).

Fallout from the battles being waged downstate reverberated throughout the State University of New York system. In I995, SUNY administrators and the SUNY Board of Trustees discussed dismantling remedial programs at the four-year campuses. One proposal was to require students lacking college-level skills to complete basic writing and math courses at two-year colleges, or even at local high schools, before they could be admitted to the baccalaureate institutions (Lively A4I).

At the State University of New York, New Paltz, many of us involved in teaching and administering courses and programs for underprepared students were aware of these discussions and became alarmed at the implications of such an edict for our students. 
Located in a small town midway between Albany and New York City, SUNY New Paltz attracts students primarily from the New York metropolitan area. Although the majority of our first-year students showed readiness for traditional composition courses, in the mid-I99os we still had a sizable number, around IO $\%$ of our incoming class, who placed into our non-credit "preparatory writing" course. (Since 1995, this percentage has remained more or less consistent.) We were concerned that discontinuing our basic writing courses would diminish the diversity of our student body by excluding students from a wide range of socioeconomic, racial, and ethnic backgrounds, students who had historically succeeded and even excelled at SUNY New Paltz.

In Spring 1995, Jan Zlotnik Schmidt, Coordinator of the Composition Program, along with Lisa Chase, Director of the Educational Opportunity Program, Bill Vasse, Provost of SUNY New Paltz, and Richard Keldar of the Center for Academic Development and Learning, began working with Lee Cross, Coordinator of the Writing Center, and faculty in the English Department who regularly taught preparatory writing. The objective was to design a model of instruction that would satisfy the demands of the SUNY Board of Trustees while meeting the needs of basic writers. We were aided in this process by having models of successful academic support services already in place at SUNY New Paltz. The Educational Opportunity Program (EOP) had been providing its students with writers' workshops for nearly a decade. These workshops, which first-year EOP students are still required to attend, are held twice a week in designated spaces in two of the residence halls and are facilitated by composition instructors. The instructor assumes the role of writing tutor, offering students oral feedback on the pieces of writing they bring to workshop (which may include assignments for courses other than composition). In addition to the type of support EOP provided to all of its first-year students, the Composition Program also offered assistance to basic writers and ESL students. The Writing Center provided in-class peer tutors to those instructors of preparatory writing and ESL sections of composition who requested them. Most instructors had the tutor come to class once a week to work individually with students on brainstorming or revision activities. Although such meetings were not mandatory, instructors often encouraged individual students to make follow-up, weekly appointments with the in-class tutor. It would be these models that we used in developing an integrated-or what Lisa Chase envisioned as "seamless" - support program for our basic writing students. 


\section{A Model Emerges}

Envisioning how the SWW Seamless Support model would work was not as difficult as one might assume, not only because other institutional models were in place, but also because our Coordinator of Composition had already redesigned the preparatory writing courses to reflect the then-recent scholarship of Shaughnessy, Bartholomae, and Rose, among others, who were advocating for the full inclusion of basic writers into the academy. As a result, instead of completing grammar workbook assignments and being limited to paragraph writing, basic writing students at New Paltz read challenging texts, kept journals, and wrote entire essays. And rather than using standardized test scores as a means for placing students into preparatory writing sections, Jan Schmidt instituted a placement essay exam, which was administered to all first-year students, not just those who failed to meet a certain SAT verbal score. As an additional assessment tool, composition instructors were required to give their students a second essay exam during the first week of class. (It should be noted that this process remains the current mechanism by which we place students into sections of SWW Composition. See Appendix A). The instructors of our preparatory writing sections, all of whom held at least an MA degree, were recruited from among the most experienced composition faculty, and most had taken Jan Schmidt's Theories of Writing course in which progressive models of writing instruction and theory were examined. The nature of the course invited conversation about teaching methods as well as a close scrutiny of rhetoricians and theorists from Quintilian through Shaughnessy. Dr. Schmidt's initial redesign of the basic writing program meant that by 1995 , when the SWW Program initiative began, the basic writing faculty at New Paltz did not have to convince administrators and other faculty to make a paradigm shift-it had been effected nearly ten years previously.

Lisa Chase, Director of EOP, shared Jan Schmidt's commitment to a process-oriented, holistic framework for the teaching of writing. Recognizing the importance of writing skills as a key component to student success, EOP required that all of their first-year students attend writing workshop sessions, staffed mainly by composition instructors, twice a week. By I995, some of these sessions were organized so that the students were being tutored by their own composition instructors. Because $40-60 \%$ of preparatory writing classes were made up of EOP students, these sections were most easily aligned. The writing faculty who were teaching these aligned workshop sessions readily envisioned how the workshop could become part of their classes-after all, 
they were already working in this way with their EOP students-and they urged that the extra workshop hour (the second hour was dropped for reasons which will follow) should immediately precede or follow the time scheduled for the class. Because EOP writing workshops were held in computer labs, the faculty also suggested that the extra workshop hour be scheduled in a computer lab. Both recommendations were followed.

Just as with the integrated writing workshop, the third component of the SWW model, individual tutoring, grew out of a pre-existing program. ESL sections of Composition I and II were already assigned in-class tutors. Peer tutors, often juniors or seniors but sometimes graduate students, attended one class session a week and then worked individually with those students who requested extra assistance. While those of us designing the SWW Program were interested in having an in-class tutor, we felt strongly that if we were to offer individual tutoring, it should be mandatory. (In our experience, many students who needed tutoring often did not seek it out.) Recognizing the possibility of student resistance and possible scheduling difficulties, we decided to incorporate only one hour of writing workshop and to replace the second workshop hour with an hour of tutoring which could be scheduled at the student's convenience. Later, a second hour of workshop was added for ESL students with the lowest levels of proficiency in written and spoken English.

The result of our efforts in and by 1995 is a model that challenges students to complete, in two semesters, the work that had previously taken three or more semesters. To sum up, students enrolled in SWW composition courses receive three academic credits for: three hours of class; one or two hour(s) of workshop; and one hour of individual tutoring.

In Fall I996, six sections of Composition I SWW were offered in place of preparatory writing. Our hope was that some of the SWW students would meet the exit criteria for Composition I during that first semester so that they could move into Composition II. At that time, exiting criteria included not only passing Composition I with a " $\mathrm{D}$ " or higher, but also passing a timed essay writing exam, which was graded pass/fail by two faculty members who had not taught the student. (We have since moved to a portfolio review at the end of Composition I; portfolios are also graded pass/fail by two readers, although one is the student's instructor.) In December of 1996, we were pleasantly surprised at the outcome- $67 \%$ of the students had passed into Composition II. By Fall 1997, the pass rate of our SWW students (75\%) was closer to being equivalent to those of students in "regular" sections of Composition I (9I\%). Pass rates continued to improve, and by 2002, data 
revealed that not only were our students' pass rates into Composition II nearly equivalent to those of their cohorts, but so were retention and graduation rates. And perhaps most surprisingly to us, the GPAs of students who had been enrolled in SWW Composition classes were almost equivalent to students enrolled in non-SWW sections when measured at the end of their first year as well as six years out (See Appendix B). So what had begun as an effort to resist an impending exclusionary policy resulted in a robust curricular design that actually accelerated the progress of our basic writing students toward their Bachelor's degrees.

\section{Seamless Support: In the Classroom, Workshop, and Beyond}

When discussing the SWW Seamless Support model with parties both inside and outside the academy, our faculty often speak about how the model provides a framework for building community. Since the interest in learning communities has grown in recent years, we often place the model in this context, noting that the SWW Program places the same emphasis on "increased intellectual interaction with faculty and fellow students" (Gabelnick et. al., qtd. in Kellogg 2). Just as learning communities seek to facilitate the first-year student's transition from high school and home to college, our model has as one of its central objectives the creation of spaces where students can become self-assured members of the academic community. The classroom, workshop, and Writing Center are designed to be places where students can experiment with language, grow as writers, and establish relationships with faculty and peers.

In the classroom, these communities develop around the shared experiences of students and instructors as they grapple with texts, both in terms of analyzing outside texts as well as producing and critiquing their own. (It is not uncommon for instructors to share their own writing with students and/or to model best practices with class assignments.) Instructors are free to choose their own textbooks, and in the case of Composition II, use a theme-based approach to teaching their courses. All Composition I courses require that students write four out-of-class essays of approximately 750 words each. These essays move from more personal, exploratory essays to expository writing, analysis, and argument. In Composition II, students are expected to write four expository analysis and/or argument essays, one of which is a research paper of least $\mathrm{I}, 250$ words. Because SWW and non-SWW composition courses share the same objectives and requirements, class time in both courses is spent in similar ways: discussing essays and other literature, 
analyzing and actively engaging in the writing process, reviewing grammar and other conventions of English, and acquiring research skills.

While class time is, of course, an important part of the SWW Program, it is the workshop hour that sets the program apart from our other sections of composition; hence the designation, Supplemental Writing Workshop. During workshop, students engage in tasks which help them to think critically not only about their writing, but also their positions within the academic community. We would describe the writing workshop portion of the SWW Program using Edward Soja's concept of "thirdspace" (Mauk), just as Grego and Thompson do in Teaching Writing in Third Spaces. The workshop is designed to be a space where students are freed from the constraints of the traditional classroom setting, where they can step back and evaluate their writing in a context which encourages broader critiques of the academy, their roles as students, as well as their roles in the world outside of academia.

The workshop hour, which immediately precedes or follows the class period, is held in a computer lab, necessitating that instructors and students move from one space to another. In addition to this literal shift in perspective, there is a figurative shift as well. While classroom time is managed by the instructor, activities in the lab are primarily student-directed, with the instructor, as well as the in-class tutor, acting as facilitators and sounding boards for ideas. Students use this time for brainstorming and drafting, revising, and other hands-on writing assignments. In addition, the labs can be used for small-group assignments, from preparing PowerPoint presentations to conducting group research assignments on the library's electronic databases or on the Web.

Much has been written over the years about the pedagogical benefits and drawbacks of computer lab instruction, and it is not our intention here to critique specific practices; yet we feel it is important to briefly conceptualize our use of the computer labs in the creation of thirdspace. While acknowledging the complex relationships among corporate hierarchical structures, software design, and the student's use of computer tools, our faculty have observed that students are increasingly using the Internet-in all its various facets - to question and sometimes even resist the dominant ethos of the academy. The digital divide, which once meant that computers were accessible only to middle-class students, has narrowed. While it may be true that "even within the online world true democracy is a polite fiction" (Spooner and Yancey 27I), students from a wide range of economic backgrounds come to college with at least a basic knowledge of how to use word processing and search the Internet. In the computer lab, the world beyond 
the classroom walls is now at their fingertips, so that the voices of those who have been marginalized share the same desktop space as those whose words are enshrined in the canons of the various disciplines. Complaints about Wikipedia and other non-academic sites notwithstanding, these alternative sites of knowledge offer students perspectives from which to critique, perhaps more holistically than ever before, what they are reading and hearing in the classroom. In some cases, these alternate spaces even allow students to engage in the process of knowledge-making through contributing to wikis, blogs, and discussion boards. And even when the university ostensibly devalues these forms of knowledge (i.e., "You can't cite Wikipedia as a source."), these sites offer students vantage points outside the academy from which to assess the ways in which knowledge in a particular field is constituted.

In creating a student-centered workshop space where the worlds inside and outside the academy are permitted to intersect, the instructor's role necessarily changes. As can be inferred from the chart on page the workshop hour always has the potential of being the most dynamic part of the SWW course because the students, instructor, and tutor are all present. During the workshop hour, the instructor's role shifts-either overtly or more subtlyfrom that of teacher to tutor. While this transformation is deliberate in the sense that the instructor has planned to move around the classroom in order to work with students individually, the tutor's presence in the workshop often heightens the instructor's (and perhaps the students') awareness of this shift in roles. Both the tutor and instructor engage in the same activities, usually one-on-one discussions with students about assignments. They report using the workshop time in much the same way that Tassoni and Lewiecki-Wilson define the purpose of the writing studio, as a time and place for "students and instructors [to] work together ... to uncover the rhetorical situation ... of particular writing assignments; teacher expectations; and social issues in students' lives, home, and work, and in the university" (70). As the Educational Opportunity Program had discovered when implementing its aligned Writing Workshop sections, having the teacher assume the role of tutor means that the students are receiving critical assessment of their work directly from the instructor, not only on paper or during a ten- or fifteen-minute office meeting, but in informal, one-on-one work sessions where texts can be analyzed and even manipulated. Both student and faculty questions about a work in progress can be answered, and instructors report having a better sense of student perception of a particular assignment. Students also seem more willing to express negative reactions to an assignment while in the workshop setting, perhaps as a result of perceiving the instructor in a different role. 
An important outcome of working with students in this way has been increased opportunities for effective communication between student and instructor. Communicating with instructors is, as Grego and Thompson have pointed out, a process which many basic writers find frustrating:

The non-traditional student's job is ... made all the harder when the academy consistently pretends that the mental processes which deal with the personal and interpersonal have little to do with student learning and performance, and the academy's evaluation of that performance. Over time these students may give up trying to find a "match" between what their experience of writing is and how the results of that experience are responded to by their educational environments. ("Repositioning Remediation" 79)

Those of us who teach in the SWW Program have found that working with students in the role of a tutor not only helps them to decode instructor feedback, but also forces instructors both to analyze and reflect on our own meanings when using common phrases ("too wordy"; "needs more details"; "expand this idea"). These comments, which we read days or even weeks after writing them, are artifacts from a past engagement with the text, and, interestingly, we sometimes find ourselves struggling to interpret their meanings. Perhaps our work as tutors helps to reveal to students the true nature of language, with its always shifting meaning, as well as our own successes and failures at communicating with our readers. Certainly, more research needs to be done in terms of understanding how the instructor shifts her role and how students perceive this shift.

As we hope we have shown in our discussion of the workshop hour, a primary objective of the SWW Seamless Support model is to create spaces basic writers can call their own in an environment that has often been traditionally dismissive of, and sometimes even hostile, to their presence. Before moving on to a consideration of how tutoring is integrated into this design, we will briefly describe another space where our students are given the opportunity to literally discover their voices in the academy. Each semester, students hold a reading that is open to the public, providing them the opportunity to share their writing with the entire campus community, which often includes such campus VIPs as the provost and president. In conjunction with the reading, the students publish Fresh Perspectives, a collection of essays, poems, fiction, and nonfiction. In Spring 2007, our ESL/SWW instructor, Penny Freel, developed a new journal with her students: ESL Exchanges, a 
publication of exploratory writings on food and family that includes recipes from the students' native cultures. Over the years, we have discovered that students often choose personal narratives rather than samples of their academic writing to submit for publication. This is not surprising. In his essay "Narrative Discourse and the Basic Writer," Norbert Elliot observes that narrative writing "is the most significant form of discourse for [basic] writers" as it is "through narrative, [that] basic writers incorporate the world of the academy into their own lives" (I9).

\section{Seamless Support: In the Writing Center}

Finally, the concept of seamless support is carried over into the individual tutoring component, which is staffed by tutors who work closely with the instructor. Before the semester begins, tutors are assigned to a specific section of SWW composition and meet with the instructor to discuss class objectives. The majority of our in-class tutors are teaching assistants enrolled in our Master's program, so it is likely that the instructor and tutor already know each other and that the tutor is well-versed in the requirements of the composition program. Once the semester is underway, the instructor and tutor typically discuss student progress at the start of the workshop hour, so that both the tutor and instructor are made aware each other's concerns. In the past, we experimented with formalizing the dialogue between them by having the tutor keep an attendance log with comments which was then turned in to the instructor weekly. However, instructors reported that they got more out of talking directly to the tutor as the comments on the official attendance log were, by necessity, cursory. We have also found that instructors and tutors often continue these conversations via email or in person.

In addition to bringing their own training in composition and rhetorical theory and classroom teaching experience to the tutoring sessions, the tutors are also students themselves, and this positions them in a mediatory role. Tutors not only provide academic support but often lend a sympathetic ear to student concerns. We have found that students are often more quickly able to develop a meaningful relationship with the tutor, who is closer to the student's age and position within the academy. That the tutor spends at least two hours with each student per week, between workshop and tutoring sessions, further helps to establish this relationship.

The comments of Meri Weiss, a former tutor who is now an instructor of composition at the School of New Resources, reveals the way in which students sometimes share their personal lives with a sympathetic tutor: 
Many [of the students] said that their parents had sacrificed so much for them to live in America and attend college, and they felt pressure/obligation/pride to illustrate to their parents both that the sacrifice was worthwhile and that they were worthy of it. They loved getting good grades and succeeding. The domino effect of working hard, earning a high grade on an essay or test and then earning a solid B or A- for the semester really affected them; they became living proof to themselves that academic dedication pays off in many ways.

Instructors are not always aware of the multiple pressures first-year students are under and often learn of them only when a student finds herself in a situation requiring accommodations (extensions on papers, excused absences, etc.). While we would never ask a tutor to betray a student's confidence by sharing personal information, the tutor does provides important feedback to the instructor about the assignments, students' progress, and individual problems she may see in students' work.

Finally, we feel it is important to point out the role of tutor training in the SWW Seamless Support model. As a result of Sarah Gardner's and Mark Bellomo's (former and current coordinators of the Writing Center) leadership, the College Reading and Learning Association granted its Level I Certification to the Center in 2005. In-class tutors are expected to attend weekly training sessions, and are also encouraged to work towards nationally recognized CRLA certification. Training ranges from discussions of recent research in the area of composition and rhetoric to workshop sessions, such as those led by ESL specialists and staff from the office of the Disability Resource Center.

\section{Assessment: Our Ten Year Anniversary}

Identifying how student perceptions of their own writing have changed, and how the design of the SWW Program has influenced/mediated this change, is the primary focus of our current research. To this end, we have recently begun reviewing reflective letters students included in their final portfolios at the end of Composition I. We are planning to conduct follow-up interviews with students, such as the one who wrote the following:

Since the course, I feel a bit more confident in my writing. . . . I still have some trouble getting some thoughts clearly written and 
writing strong sentence structures but working along side someone like a tutor has been truly a big help. For me it is important to get some feedback and some guidance.

As well as this student:

After experiencing this class I have gained a new respect for writing. I enjoy being able to have a thought that I can put together to make an essay that I am proud to have my name on top.

After reading almost a hundred letters from students in various sections across a range of years, we are beginning to identify common themes centered on students' emerging sense of agency as writers. Certainly, some may exaggerate how much their writing has improved or may insist that "they have truly grown as writers" in order to please us and perhaps even to earn a higher grade (although the letters themselves are never graded). Still, we believe these letters are giving us a better insight into student perceptions of their own writing and will serve as a rich source of follow-up study.

The letters written by a majority of our SWW and ESL/SWW students often speak about how they felt about their writing skills prior to entering college and a college writing class. For example, one student's reflective letter begins with her declaration that she has always been "disappointed" by her lack of English language writing skills. As other basic writing instructors have noted, students often express their feelings of inadequacy as writers in moral or social terms. For example, another student writes:

At the beginning I used to hate sharing my writing with other people, especially in peer critique. I was not sure of the way I used to express my ideas.... I was ashamed of my writing.

This student's reflection reminds us of the important role basic writing programs have in helping students to gain confidence in using what Richard Rodriguez calls "the language of public life" (qtd. in Torres). Students become uncomfortable with writing and speaking in high school for a variety of reasons, often growing frustrated with their attempts to conform to the conventions of standard English, conventions which are, of course, socially constructed. Thus, feelings of "shame" become associated with the writing process. 
While the letters of our students do not reveal a sophisticated awareness of how the dominant culture attempts to fix their places within (and without) the academy, what we have found is that these letters express an increasing sense of self-confidence as well as an awareness that they are stake-holders in the academy. For example, one student writes:

My attitude toward writing has changed, because now I do not write an essay because the teacher told me to do so. I do it because I like it and enjoy it. ... Through the semester I saw my writing develop and it was satisfied for me.... Now, I do not mind reading in front of the entire class because I am reading my feelings, the information I searched, or my opinion.

As discussed earlier in this article, one of the SWW Program's central goals is to create a supportive community among our students, faculty, and tutors, a community that places value on student ideas and risk-taking. Whether our students can clearly articulate this shift in values from the high school to the college classroom is not yet certain (another area we hope to assess in a follow-up study), but it is clear that, for the majority of our students, their perceptions of themselves as writers have changed by the end of Composition I.

While we are primarily interested in qualitative assessment, quantitative assessment has become the by-word of administrators and policy-makers seeking to make systemic changes to both K-I2 as well as college-level instruction. As basic writing instructors know, assessing student progress is complex, and assessments of only the short-term are of limited value. In addition, the ways in which we assess our students, as Mike Rose and David Bartholomae, among others, have pointed out, is suspect, sometimes revealing more about institutional biases than about student writing.

Be that as it may, those outside of our programs who evaluate us often use quantitative data to form opinions about the "success" of a particular program and use such data to argue for curricular changes. In 2002, SWW Program Coordinator, Rachel Rigolino, requested that the Office of Institutional Research compare the graduation rates and GPAs of students who had been in the SWW Program with those of their cohorts. The results showed that students in the SWW Program were achieving similar rates of success as their peers using standard benchmarks. Additional data was collected in late 2006, the ten year anniversary of the inception of the SWW Program. The charts in Appendix B illustrate how closely the data collected on SWW 
students mirrors that of their counterparts. We have found this data to be helpful when discussing basic writing with interested parties both on campus and off.

While there remains much to be analyzed and researched in terms of the pedagogical underpinnings of the SWW Program and the Seamless Support model, we believe that this model's success can be used to find ways to talk to those outside of the classroom about basic writers and basic writing programs. What follows are some insights which can be shared with interested parties.

Given access to enough resources, basic writers can progress to degree at the same rate as other students. Knowing that administrators might balk at spending extra money to provide an hour of workshop and tutoring to students, we were careful to point out that we would be eliminating an extra layer of classes (preparatory writing), an argument which won us enough time to begin the pilot program in Fall I996. If we were making the same proposal today, we would express this result in a different way: namely, our data shows that the additional resources expended on our basic writing students results in quicker progress to degree than under the old, three-semester model. In addition to appealing to administrators concerned with accrediting bodies, this rather straight-forward observation has the potential to change the public perception of basic writers.

These resources are similar to those being allocated to learning communities at campuses around the country. Of course, it is not only basic writing faculty who must contend with public perceptions of their programs. College administrators are also finding themselves driven to institute changes often as a result of data published by widely read college guides such as U.S. News and World Report: America's Best Colleges. The effort to increase first-year retention rates has been fueled, in part, by public perception, and the Learning Community movement has greatly benefited from this trend. The Seamless Support model is, it can be argued, a type of Learning Community, and certainly our data on retention rates can be used to buttress this position. If institutions are committing expenditures in order to improve retention rates, Seamless Support models of instruction for basic writers should be included.

\section{External measurements are not necessary to determine} student success. Measuring student achievement through standardized testing is, of course, a well-entrenched practice in our K-I2 schools, and it is not improbable that state governments might eventually mandate benchmark exams at various points in a college student's academic career. Heated 
debates about the merits of such exams are likely to continue ad nauseum, and it is unlikely that, at least in the public forum, nuanced arguments based on scholarly research will win the day. However, what our longitudinal study of the SWW Program shows is that meaningful comparisons can be made among cohorts at a particular college. While we would need further research to demonstrate cause and effect between specific components of the program and data on, for example, student GPAs, we can give a broad picture of the program's success. What can be shown is that students placed into the SWW Seamless Support model are succeeding according to the traditional tools to measure success: pass rates into Composition II, retention rates, graduation rates, and GPAs.

Including student voices is necessary. Now that we have collected quantitative data about the SWW Seamless Support model, we plan to conduct more research in the area of student perception. How do students perceive classroom time, workshop time, and tutoring time? Do students see the model as being "seamless" or do they use descriptors that reflect other visions of the program? How do students view the roles of the instructor in the classroom and the workshop? The role of the tutor inside and outside of the Writing Center? In addition to collecting information from recent students, we plan to solicit feedback from students who have been out of the program for several years, including, we hope, from students enrolled in the first SWW classes in 1996. As basic writing instructors, we profess to value our students' voices, and if this is true, then we must find ways to bring them into the public discussion about basic writing programs and their place in the academy. While we may draw attention to the success of various models through the presentation of data and research, debates are rarely won on the strength of logical arguments alone. Once we professionals have caught the public's ear, the voices of our students may be what finally have the power to effect lasting change.

\section{Works Cited}

Adler-Kassner, Linda, and Susanmarie Harrington. "In the Here and Now: Public Policy and Basic Writing." Journal of Basic Writing 25.2 (2006): $27-48$.

Andrews, Jacqueline, and Kirsten Rowe. "Composition Mean Grade Point Average." Chart. Office of Institutional Research and Planning. SUNY 
New Paltz. January 2007.

. "Composition Retention/Graduation Rate." Chart. Office of Institutional Research and Planning. SUNY New Paltz. January 2007.

Bartholomae, David. "The Tidy House: Basic Writing in the American Curriculum." Journal of Basic Writing I2.I (I993): 4-2I.

The City College Undergraduate Bulletin: 2005-2007. 24 November 2007 <http:// wwwi.ccny.cuny.edu/CCNYBulletin/upload/2005_07_UGraduateBulletin.PDF $>$.

Cooper, Sandi. “Remediation's End: Can New York Educate the Children of the 'Whole People?"” Academe 84.4 (I998): I4-I7. ProQuest. Sojourner Truth Library. New Paltz, NY. 2 June 2007 <http://proquest.umi.com. libdatabase.newpaltz.edu>.

CUNY Community College Conference. "Myths and Facts about Remediation at CUNY." Fall I998. I9 June 2007 < http://www.psc-cuny. org/mythfact.htm >.

Elliot, Norbert. "Narrative Discourse and the Basic Writer." Journal of Basic Writing I4.2 (I995):I9-30.

Glau, Gregory R. "Stretch at Io: A Progress Report on Arizona State University's Stretch Program." Journal of Basic Writing 26.2 (2007): PAGE NUMBERS TO COME.

Grego, Rhonda, and Nancy Thompson. "Repositioning Remediation: Renegotiating Composition's Work in the Academy." College Composition and Communication 47.I (I996): 62-84. JSTOR. Sojourner Truth Library. New Paltz, NY. 30 May 2007 <http://www.jstor.org.libdatabase.newpaltz.edu>.

. Teaching Writing in Third Spaces: The Studio Model. Publisher's Abstract. Carbondale, Ill: Southern Illinois UP: 2008. 7 July 2007 < http://www. siu.edu/ siupress/books/GregoThompsonTeachingWriting.html>.

Horner, Bruce. Review of Mainstreaming Basic Writers: Politics, and Pedagogies of Access. Eds. Gerri McNenny and Sallyanne H. Fitzgerald. Mahwah, NJ: Erlbaum Lawrence, 2OOI. Composition Studies 32.I (2004): 32-I38. EBSCOhost. Sojourner Truth Library. New Paltz, NY. 4 June 2007 < http://web. ebscohost.com.libdatabase.newpaltz.edu>.

Kellogg, Karen. “Learning Communities.” ERIC Digest. ERIC Clearinghouse on Higher Education. I999. ED4305I2 I999-00-00.

Knowlton, Steven. "Questions about Remedial Education in a Time of Budget Cuts."New York Times 7 June I995: Bri. Historical New York Times. ProQuest.Sojourner Truth Library. New Paltz, NY. 4June 2007 < http://web. ebscohost.com.libdatabase.newpaltz.edu>. 
Lalicker, William B. "A Basic Introduction to Basic Writing Program Structures: A Baseline and Five Alternatives." BWe: Basic Writing e-Journal I.2 (I999). 7 May 2007 <http://www.asu.edu/clas/english/composition/ cbw/bwe_fall_I999.htm $>$.

Lively, Kit. State Notes. The Chronicle of Higher Education 3 Nov. I995: A4I. ProQuest. Sojourner Truth Library. New Paltz, NY. 30 May 2007<http:// proquest.umi.com.libdatabase.newpaltz.edu> .

Mauk, Johnathon. “Location, Location, Location: The 'Real' (E)states of Being, Writing, and Thinking in Composition." College English 64.4 (2003): 368-88.

Meyers, Bart. “The CUNY Wars.” Social Text 5I (I997): II9-30. JSTOR. Sojourner Truth Library. New Paltz, NY. 2 June 2007 <http://www.jstor. org.libdatabase.newpaltz.edu>.

National Center for Education Statistics. "Remedial Education at Higher Education Institutions in Fall I995." 25 May 2007 < http://nces.ed.gov/ surveys/peqis/publications/97584/index.asp?sectionID $=\mathrm{I}>$.

Rose, Mike. "Narrowing the Mind and Page: Remedial Writers and Cognitive Reductionism." College Composition and Communication 39.3 (I988): 267-302. JSTOR. Sojourner Truth Library. New Paltz, NY. 2 June 2007 $<$ http://www.jstor.org.libdatabase.newpaltz.edu> .

Shaughnessy, Mina. Errors and Expectations: A Guide for the Teacher of Basic Writing. Oxford UP, I979.

Southern Illinois University Press. Review of Teaching Writing in Third Spaces. Rhonda C. Grego and Nancy S. Thompson. Southern Illinois UP, 2008 I Nov. 2007 <http://www.siu.edu/ siupress/books/GregoThompsonTeachingWriting.html $>$.

Spooner, Michael, and Kathleen Yancey. "Posting on a Genre of Email." College Composition and Communication 47.2. (I996): 252-78. JSTOR. Sojourner Truth Library. New Paltz, NY. 24 Nov. 2007 <http://www. jstor.org.libdatabase.newpaltz.edu >.

Tassoni, John Paul, and Cynthia Lewiecki-Wilson. "Not Just Anywhere, Anywhen: Mapping Change through Studio Work." Journal of Basic Writing 24.I(2005): 68-92.

Torres, Hector A. “'I Don't Think I Exist': Interview with Richard Rodriguez.” MELUS.28.2 (2003): I64-202. JSTOR. Sojourner Truth Library. New Paltz, NY. I5 Nov. 2007 <http://www.jstor.org.libdatabase.newpaltz.edu>.

Weiss, Meri. Email interview. 25 July 2007. 
Appendix A:

State University of New York at New Paltz Placement Rubric

\begin{tabular}{|c|c|c|c|c|c|}
\hline Level: & 5 (honors) & $\begin{array}{l}4 \text { (Exit Level } \\
\text { Comp I) }\end{array}$ & $\begin{array}{l}3 \text { (Entrance } \\
\text { Level Comp } \\
\text { I) }\end{array}$ & $2(\mathbf{S W W})$ & $\mathbf{I}(\mathbf{S W W})$ \\
\hline \multicolumn{6}{|c|}{$\begin{array}{l}\text { MEANING/CONTENT: the extent to which the response exhibits sound understanding, inter- } \\
\text { pretation, and analysis of the task or text: }\end{array}$} \\
\hline Thesis: & $\begin{array}{l}\text { Exhibits a } \\
\text { thesis that is } \\
\text { highly insight- } \\
\text { ful, original, } \\
\text { and cogently } \\
\text { stated. Key } \\
\text { terms are } \\
\text { defined in } \\
\text { depth. }\end{array}$ & $\begin{array}{l}\text { Exhibits a } \\
\text { thesis that is } \\
\text { insightful and } \\
\text { clearly stated. } \\
\text { Key terms are } \\
\text { defined. }\end{array}$ & $\begin{array}{l}\text { States thesis. } \\
\text { Defines some } \\
\text { key terms. }\end{array}$ & $\begin{array}{l}\text { States vague } \\
\text { thesis. Does } \\
\text { not define } \\
\text { terms. }\end{array}$ & $\begin{array}{l}\text { Presents no } \\
\text { thesis. Does } \\
\text { not define } \\
\text { terms. }\end{array}$ \\
\hline Analysis: & $\begin{array}{l}\text { Reveals both } \\
\text { in-depth } \\
\text { analysis and } \\
\text { independent } \\
\text { thinking; } \\
\text { makes insight- } \\
\text { ful and original } \\
\text { connections. }\end{array}$ & $\begin{array}{l}\text { Reveals } \\
\text { in-depth } \\
\text { analysis; makes } \\
\text { insightful con- } \\
\text { nections. }\end{array}$ & $\begin{array}{l}\text { Conveys a } \\
\text { thorough } \\
\text { understanding } \\
\text { of topic and } \\
\text { makes clear } \\
\text { connections. }\end{array}$ & $\begin{array}{l}\text { Conveys a basic } \\
\text { understanding } \\
\text { of topic; makes } \\
\text { a few connec- } \\
\text { tions. }\end{array}$ & $\begin{array}{l}\text { Provides an } \\
\text { inaccurate } \\
\text { understanding } \\
\text { of topic with } \\
\text { unclear con- } \\
\text { nections. }\end{array}$ \\
\hline \multicolumn{6}{|c|}{ DEVELOPMENT: the extent to which ideas are elaborated using specific $\&$ relevant evidence: } \\
\hline Ideas: & $\begin{array}{l}\text { Develops ideas } \\
\text { expertly; and } \\
\text { demonstrates } \\
\text { an unusual } \\
\text { ability to inter- } \\
\text { est a reader } \\
\text { through use } \\
\text { of substantive } \\
\text { details. }\end{array}$ & $\begin{array}{l}\text { Develops ideas } \\
\text { clearly and } \\
\text { fully, making } \\
\text { effective use of } \\
\text { a wide-range of } \\
\text { relevant/spe- } \\
\text { cific details. }\end{array}$ & $\begin{array}{l}\text { Develops ideas } \\
\text { clearly; uses } \\
\text { relevant/spe- } \\
\text { cific details. }\end{array}$ & $\begin{array}{l}\text { Develops ideas } \\
\text { briefly; uses } \\
\text { some detail. }\end{array}$ & $\begin{array}{l}\text { Presents } \\
\text { incomplete or } \\
\text { undeveloped } \\
\text { ideas. }\end{array}$ \\
\hline $\begin{array}{l}\text { Paragraph } \\
\text { Develop- } \\
\text { ment: }\end{array}$ & $\begin{array}{l}\text { Clearly devel- } \\
\text { ops paragraphs } \\
\text { directly related } \\
\text { to thesis; each } \\
\text { paragraph } \\
\text { extends the } \\
\text { main idea. }\end{array}$ & $\begin{array}{l}\text { Clearly devel- } \\
\text { ops paragraphs } \\
\text { directly related } \\
\text { to thesis; para- } \\
\text { graphs con- } \\
\text { tribute to the } \\
\text { thesis/main } \\
\text { idea. }\end{array}$ & $\begin{array}{l}\text { Most para- } \\
\text { graphs relate to } \\
\text { the thesis. }\end{array}$ & $\begin{array}{l}\text { Some para- } \\
\text { graphs relate to } \\
\text { the thesis. }\end{array}$ & $\begin{array}{l}\text { Few or no para- } \\
\text { graphs relate to } \\
\text { the thesis. }\end{array}$ \\
\hline Level: & 5 (Honors) & $\begin{array}{l}4 \text { (Exit Level } \\
\text { Comp I) }\end{array}$ & $\begin{array}{l}3 \text { (Entrance } \\
\text { Level Comp } \\
\text { I) }\end{array}$ & $2(\mathbf{S W W})$ & $\mathbf{I}(\mathbf{S W W})$ \\
\hline \multicolumn{6}{|c|}{ ORGANIZATION: the extent to which the response exhibits direction shape and coherence: } \\
\hline $\begin{array}{l}\text { Organiza- } \\
\text { tion: }\end{array}$ & $\begin{array}{l}\text { Maintains a } \\
\text { clear, coherent } \\
\text { essay structure } \\
\text { including } \\
\text { exceptional } \\
\text { command of } \\
\text { essay format. }\end{array}$ & $\begin{array}{l}\text { Maintains } \\
\text { clear, appropri- } \\
\text { ate focus; ex- } \\
\text { hibits a logical, } \\
\text { coherent struc- } \\
\text { ture through } \\
\text { appropriate } \\
\text { transitions. }\end{array}$ & $\begin{array}{l}\text { Maintains a } \\
\text { clear, appropri- } \\
\text { ate focus; } \\
\text { exhibits a logi- } \\
\text { cal sequence of } \\
\text { ideas through } \\
\text { appropriate } \\
\text { transitions. }\end{array}$ & $\begin{array}{l}\text { Establishes } \\
\text { but does not } \\
\text { maintain ap- } \\
\text { propriate focus; } \\
\text { inconsistencies } \\
\text { in sequence of } \\
\text { ideas/transi- } \\
\text { tions. }\end{array}$ & $\begin{array}{l}\text { Lacks an } \\
\text { appropriate } \\
\text { focus, but } \\
\text { suggests some } \\
\text { organization. }\end{array}$ \\
\hline $\begin{array}{l}\text { Introduc- } \\
\text { tion: }\end{array}$ & $\begin{array}{l}\text { Creates an } \\
\text { engaging focus } \\
\text { on topic. }\end{array}$ & $\begin{array}{l}\text { Clearly focuses } \\
\text { on topic; con- } \\
\text { veys a powerful } \\
\text { message to the } \\
\text { reader. }\end{array}$ & $\begin{array}{l}\text { Focuses on } \\
\text { topic in the } \\
\text { introduction. }\end{array}$ & $\begin{array}{l}\text { Lacks a focus } \\
\text { on topic/pur- } \\
\text { pose in intro- } \\
\text { duction. }\end{array}$ & $\begin{array}{l}\text { Contains no } \\
\text { focus on topic } \\
\text { in introduc- } \\
\text { tion. }\end{array}$ \\
\hline Conclusion: & $\begin{array}{l}\text { Provides fur- } \\
\text { ther thinking } \\
\text { and implica- } \\
\text { tions (e.g., sug- } \\
\text { gests further } \\
\text { research, or } \\
\text { extends key } \\
\text { ideas). }\end{array}$ & $\begin{array}{l}\text { Extends, } \\
\text { connects, and } \\
\text { comments on } \\
\text { key ideas. }\end{array}$ & $\begin{array}{l}\text { Summarizes } \\
\text { key ideas. }\end{array}$ & $\begin{array}{l}\text { Somewhat } \\
\text { restates main } \\
\text { idea. }\end{array}$ & $\begin{array}{l}\text { Contains an } \\
\text { incomplete } \\
\text { conclusion or } \\
\text { conclusion is } \\
\text { missing. }\end{array}$ \\
\hline $\begin{array}{l}\text { Overall Orga- } \\
\text { nization: }\end{array}$ & $\begin{array}{l}\text { Exceeds re- } \\
\text { quirements of } \\
\text { assignment. }\end{array}$ & $\begin{array}{l}\text { Consistently } \\
\text { meets require- } \\
\text { ments. }\end{array}$ & $\begin{array}{l}\text { Meets require- } \\
\text { ments. }\end{array}$ & $\begin{array}{l}\text { Meets some } \\
\text { requirements }\end{array}$ & $\begin{array}{l}\text { Meets few/no } \\
\text { requirements. }\end{array}$ \\
\hline
\end{tabular}


Rachel Rigolino and Penny Freel

\begin{tabular}{|c|c|c|c|c|c|}
\hline & 5 (Honors) & $\begin{array}{l}4(\text { Exit Level } \\
\text { Comp I })\end{array}$ & $\begin{array}{l}3 \text { (Entrance } \\
\text { Level Comp } \\
\text { I) }\end{array}$ & $2(S W W)$ & I (SWW) \\
\hline \multicolumn{6}{|c|}{$\begin{array}{l}\text { LANGUAGE USE: the extent to which the response reveals an awareness of audience and pur- } \\
\text { pose through an effective use of words, sentence structure, and sentence variety: }\end{array}$} \\
\hline Description: & $\begin{array}{l}\text { Demonstrates } \\
\text { a level of } \\
\text { professional } \\
\text { excellence in } \\
\text { style, }\end{array}$ & $\begin{array}{l}\text { Creates vivid } \\
\text { "pictures" } \\
\text { through con- } \\
\text { crete language, } \\
\text { rich sensory } \\
\text { detail, and lit- } \\
\text { erary devices. }\end{array}$ & $\begin{array}{l}\text { Creates "pic- } \\
\text { tures" through } \\
\text { concrete } \\
\text { language, } \\
\text { sensory detail } \\
\text { and literary } \\
\text { devices. }\end{array}$ & $\begin{array}{l}\text { Uses concrete } \\
\text { language, } \\
\text { sensory detail, } \\
\text { and literary } \\
\text { devices. }\end{array}$ & $\begin{array}{l}\text { Uses little con- } \\
\text { crete language, } \\
\text { sensory detail, } \\
\text { or literary } \\
\text { devices. }\end{array}$ \\
\hline Word Choice: & word choice, & $\begin{array}{l}\text { Uses sophisti- } \\
\text { cated, precise } \\
\text { vocabulary. }\end{array}$ & $\begin{array}{l}\text { Uses effective } \\
\text { word choices. }\end{array}$ & $\begin{array}{l}\text { Uses some } \\
\text { effective word } \\
\text { choices. }\end{array}$ & $\begin{array}{l}\text { Uses few } \\
\text { effective word } \\
\text { choices. }\end{array}$ \\
\hline $\begin{array}{l}\text { Sentence } \\
\text { Variety: }\end{array}$ & $\begin{array}{l}\text { complexity of } \\
\text { language, }\end{array}$ & $\begin{array}{l}\text { Uses well- } \\
\text { varied sentence } \\
\text { structure } \\
\text { throughout. }\end{array}$ & $\begin{array}{l}\text { Exhibits good } \\
\text { sentence struc- } \\
\text { ture/ variety. }\end{array}$ & $\begin{array}{l}\text { Uses occasional } \\
\text { sentence va- } \\
\text { riety. }\end{array}$ & $\begin{array}{l}\text { Uses little sen- } \\
\text { tence variety. }\end{array}$ \\
\hline $\begin{array}{l}\text { Voice/Sense } \\
\text { of Audience: }\end{array}$ & $\begin{array}{l}\text { and sense of } \\
\text { audience. }\end{array}$ & $\begin{array}{l}\text { Has a unique } \\
\text { voice and } \\
\text { strong aware- } \\
\text { ness of audi- } \\
\text { ence. }\end{array}$ & $\begin{array}{l}\text { Exhibits evi- } \\
\text { dent awareness } \\
\text { of voice/audi- } \\
\text { ence. }\end{array}$ & $\begin{array}{l}\text { Exhibits some } \\
\text { awareness of } \\
\text { voice/audi- } \\
\text { ence. }\end{array}$ & $\begin{array}{l}\text { Exhibits a rudi- } \\
\text { mentary sense } \\
\text { of audience. }\end{array}$ \\
\hline \multicolumn{6}{|c|}{$\begin{array}{l}\text { CONVENTIONS: the extent to which the response exhibits conventional spelling, punctua- } \\
\text { tion, paragraphing, capitalization, grammar, and usage: }\end{array}$} \\
\hline $\begin{array}{l}\text { Grammar/ } \\
\text { Punctuation: }\end{array}$ & $\begin{array}{l}\text { Achieves excel- } \\
\text { lence in gram- } \\
\text { mar basics. }\end{array}$ & $\begin{array}{l}\text { Exhibits cor- } \\
\text { rect grammar } \\
\text { in smooth, } \\
\text { fluid sentences; } \\
\text { error-free } \\
\text { punctuation. }\end{array}$ & $\begin{array}{l}\text { Exhibits } \\
\text { mostly correct } \\
\text { grammar; } \\
\text { punctuation } \\
\text { errors do not } \\
\text { interfere with } \\
\text { communica- } \\
\text { tion. }\end{array}$ & $\begin{array}{l}\text { Exhibits errors } \\
\text { in grammar } \\
\text { that occasion- } \\
\text { ally interfere } \\
\text { with commu- } \\
\text { nication. }\end{array}$ & $\begin{array}{l}\text { Exhibits er- } \\
\text { rors that are } \\
\text { awkward and } \\
\text { interfere with } \\
\text { communica- } \\
\text { tion. }\end{array}$ \\
\hline $\begin{array}{l}\text { Spelling and } \\
\text { Usage: }\end{array}$ & $\begin{array}{l}\text { Exhibits error } \\
\text { free prose. }\end{array}$ & $\begin{array}{l}\text { Exhibits cor- } \\
\text { rect spelling; } \\
\text { error-free } \\
\text { prose. }\end{array}$ & $\begin{array}{l}\text { Exhibits mostly } \\
\text { correct spelling } \\
\text { and usage. }\end{array}$ & $\begin{array}{l}\text { Frequently } \\
\text { misspells and } \\
\text { misuses words. }\end{array}$ & $\begin{array}{l}\text { Excessively } \\
\text { misspells and } \\
\text { misuses words. }\end{array}$ \\
\hline $\begin{array}{l}\text { Presenta- } \\
\text { tion: }\end{array}$ & $\begin{array}{l}\text { Achieves } \\
\text { all-around } \\
\text { excellence in } \\
\text { presentation; } \\
\text { MLA format. }\end{array}$ & $\begin{array}{l}\text { Displays a } \\
\text { neat and } \\
\text { professional } \\
\text { presentation; } \\
\text { MLA format; } \\
\text { attention to } \\
\text { detail; unique } \\
\text { title. }\end{array}$ & $\begin{array}{l}\text { Demonstrates } \\
\text { a neat and } \\
\text { easy-to-read } \\
\text { presentation; } \\
\text { MLA format; } \\
\text { appropriate } \\
\text { title. }\end{array}$ & $\begin{array}{l}\text { Exhibits } \\
\text { average } \\
\text { presentation; } \\
\text { incomplete } \\
\text { format; } \\
\text { average title. }\end{array}$ & $\begin{array}{l}\text { Pays little/no } \\
\text { attention to } \\
\text { presentation; } \\
\text { no format; } \\
\text { poor/no title. }\end{array}$ \\
\hline
\end{tabular}


Re-Modeling Basic Writing

\section{Appendix B:}

\section{Composition Retention/Graduation Rates and Composition Mean GPA Comparisons}

\begin{tabular}{|c|c|c|c|c|c|c|c|c|}
\hline \multirow{2}{*}{ Cohort Entering } & \multirow{2}{*}{ Category } & \multirow{2}{*}{$\begin{array}{l}\text { Total } \\
\text { Cohort }\end{array}$} & \multicolumn{3}{|c|}{$\begin{array}{l}\text { Retention Rate } \\
\text { as of end of: }\end{array}$} & \multicolumn{3}{|c|}{$\begin{array}{l}\text { Graduation Rate } \\
\text { within: }\end{array}$} \\
\hline & & & $\begin{array}{c}\text { 1st } \\
\text { Year }\end{array}$ & $\begin{array}{l}\text { 2nd } \\
\text { Year }\end{array}$ & $\begin{array}{l}\text { 3rd } \\
\text { Year }\end{array}$ & $\begin{array}{c}4 \\
\text { Years }\end{array}$ & $\begin{array}{c}5 \\
\text { Years }\end{array}$ & $\begin{array}{c}6 \\
\text { Years }\end{array}$ \\
\hline \multirow{3}{*}{ Fall 1998} & Non-SWW & 549 & $75.6 \%$ & $628 \%$ & $60.1 \%$ & $27.0 \%$ & $49.4 \%$ & $54.5 \%$ \\
\hline & SWW & 88 & $79.5 \%$ & $68.2 \%$ & $67.0 \%$ & $21.6 \%$ & $54.5 \%$ & $60.2 \%$ \\
\hline & Total & 637 & $76.1 \%$ & $63.6 \%$ & $61.1 \%$ & $26.2 \%$ & $50.1 \%$ & $55.3 \%$ \\
\hline \multirow{3}{*}{ Fall 1999} & Non-SWW & 677 & $80.6 \%$ & $71.9 \%$ & $68.5 \%$ & $34.0 \%$ & $59.5 \%$ & $64.1 \%$ \\
\hline & sWW & 104 & $84.6 \%$ & $72.1 \%$ & $70.2 \%$ & $24.0^{0 \%}$ & $56.7 \%$ & $66.3 \%$ \\
\hline & Total & 781 & $81.2 \%$ & $72.0 \%$ & $68.8 \%$ & $32.7 \%$ & $59.2 \%$ & $64.4 \%$ \\
\hline \multirow{3}{*}{ Fall 2000} & Non-SWW & 667 & $82.9 \%$ & $66.3 \%$ & $62.1 \%$ & $29.8 \%$ & $53.2 \%$ & $57.0 \%$ \\
\hline & SWW & 117 & $83.8 \%$ & $77.8 \%$ & $73.5 \%$ & $28.2 \%$ & $59.0 \%$ & $64.1 \%$ \\
\hline & Total & 784 & $83.0 \%$ & $68.0 \%$ & $63.8 \%$ & $29.6 \%$ & $54.1 \%$ & $58.0 \%$ \\
\hline \multirow{3}{*}{ Fall 2001} & Non-SWW & 687 & $84.0 \%$ & $75.0 \%$ & $71.0 \%$ & $34.5 \%$ & $62.3 \%$ & \\
\hline & SWW & 97 & $84.5 \%$ & $79.4 \%$ & $73.2 \%$ & $29.9 \%$ & $61.9 \%$ & \\
\hline & Total & 784 & $84.1 \%$ & $75.5 \%$ & $71.3 \%$ & $33.9 \%$ & $62.2 \%$ & \\
\hline \multirow{3}{*}{ Fall 2002} & Non-SWW & 719 & $84.4 \%$ & $76.9 \%$ & $73.2 \%$ & $40.5 \%$ & & \\
\hline & SWW & 47 & $87.2 \%$ & $85.1 \%$ & $78.7 \%$ & $27.7 \%$ & & \\
\hline & Total & 766 & $84.6 \%$ & $77.4 \%$ & $73.5 \%$ & $39.7 \%$ & & \\
\hline \multirow{3}{*}{ Fall 2003} & Non-SWW & 651 & $82.8 \%$ & $74.3 \%$ & $70.8 \%$ & & & \\
\hline & $5 W W$ & 105 & $91.4 \%$ & $81.9 \%$ & $79.0 \%$ & & & \\
\hline & Total & 756 & $84.0 \%$ & $75.4 \%$ & $72.0 \%$ & & & \\
\hline \multirow{3}{*}{ Fall 2004} & Non-SWW & 573 & $86.6 \%$ & $75.9 \%$ & & & & \\
\hline & SWW & 80 & $80.0 \%$ & $688 \%$ & & & & \\
\hline & Total & 653 & $85.8 \%$ & $75.0 \%$ & & & & \\
\hline \multirow{3}{*}{ Fall 2005} & Non-SWW & 751 & $85.1 \%$ & & & & & \\
\hline & sWW & 104 & $81.7 \%$ & & & & & \\
\hline & Total & 855 & $84.7 \%$ & & & & & \\
\hline
\end{tabular}


Rachel Rigolino and Penny Freel

\begin{tabular}{|c|c|c|c|c|c|c|}
\hline \multirow[b]{2}{*}{ Cohort Entering } & \multirow[b]{2}{*}{ Category } & \multirow[b]{2}{*}{$\begin{array}{l}\text { Total } \\
\text { Cohort }\end{array}$} & \multicolumn{2}{|c|}{ 1st Year } & \multicolumn{2}{|c|}{\begin{tabular}{|l}
6 th Year \\
\end{tabular}} \\
\hline & & & $\begin{array}{c}\text { Mean Cum. } \\
\text { GPA }\end{array}$ & $\begin{array}{l}\text { Count of } \\
\text { Cum. GPA }\end{array}$ & $\begin{array}{c}\text { Mean Cum. } \\
\text { GPA }\end{array}$ & $\begin{array}{l}\text { Count of } \\
\text { Cum. GPA }\end{array}$ \\
\hline \multirow{3}{*}{ Fall 1998} & Non-SWW & 549 & 2.85 & 415 & 3.05 & 297 \\
\hline & Sww & 88 & 2.76 & 70 & 2.96 & 53 \\
\hline & Total & 637 & 2.84 & 485 & 3.04 & 350 \\
\hline \multirow{3}{*}{ Fall 1999} & Non-SWW & 677 & 2.88 & 545 & 3.09 & 429 \\
\hline & sww & 104 & 2.82 & 88 & 3.01 & 69 \\
\hline & Total & 781 & 2.87 & 633 & 3.08 & 498 \\
\hline \multirow{3}{*}{ Fall 2000} & Non-SWW & 667 & 2.90 & 550 & 3.11 & 376 \\
\hline & sww & 117 & 2.80 & 98 & 3.01 & 75 \\
\hline & Total & 784 & 2.88 & 648 & 3.09 & 451 \\
\hline \multirow{3}{*}{ Fall 2001} & Non-SWW & 687 & 2.97 & 577 & & \\
\hline & sww & 97 & 2.88 & 82 & & \\
\hline & Total & 784 & 2.96 & 659 & & \\
\hline \multirow{3}{*}{ Fall 2002} & Non-SWW & 719 & 3.04 & 607 & & \\
\hline & sww & 47 & 2.81 & 40 & & \\
\hline & Total & 766 & 3.02 & 647 & & \\
\hline \multirow{3}{*}{ Fall 2003} & Non-SWW & 651 & 3.07 & 539 & & \\
\hline & sww & 105 & 2.90 & 96 & & \\
\hline & Total & 756 & 3.05 & 635 & & \\
\hline \multirow{3}{*}{ Fall 2004} & Non-SWW & 573 & 3.14 & 494 & & \\
\hline & sww & 80 & 2.95 & 64 & & \\
\hline & Total & 653 & 3.12 & 558 & & \\
\hline \multirow{3}{*}{ Fall 2005} & Non-SWW & 751 & 3.09 & 636 & & \\
\hline & swW & 104 & 2.89 & 85 & & \\
\hline & Total & 855 & 3.06 & 721 & & \\
\hline
\end{tabular}

Notes:

1. 1st Year GPA calculated for those who returned; 6th Year GPA calculated for those who graduated.

2. Count of GPA values may be lower than those in Retention-Graduation chart due to missing GPAs.

3. Difference between means is statistically significant at $p<.05$.

\begin{tabular}{|c|c|c|c|c|c|c|}
\hline & \multicolumn{3}{|c|}{ 1st Year } & \multicolumn{3}{|c|}{ 6th Year } \\
\hline & $t$ & df & p & $t$ & df & P \\
\hline Fall 1998 & 1.270 & 86 & 0.208 & 1.592 & 348 & 0.112 \\
\hline Fall 1999 & 1.115 & 631 & 0.265 & 1.770 & 496 & 0.077 \\
\hline Fall 2000 & 1.616 & 646 & 0.107 & 2.116 & 449 & 0.035 \\
\hline Fall 2001 & 1.404 & 657 & 0.161 & & & \\
\hline Fall 2002 & 2.761 & 645 & 0.006 & & & \\
\hline Fall 2003 & 3.203 & 633 & 0.001 & & & \\
\hline Fall 2004 & 3.100 & 556 & 0.002 & & & \\
\hline Fall 2005 & 3.348 & 719 & 0.001 & & & \\
\hline
\end{tabular}




\title{
Assessing Student Writing: The Self-Revised Essay
}

\author{
Janine Graziano-King
}

ABSTRACT: In an effort to assess student writing in a way that reflects current views of writing (i.e., as a social process supported by the interaction of a number of cognitive sub-processes), and yet still seeks to determine what students can do independently, it has become a common practice to include timed essays in student portfolios. However, this practice adds to the already heavy cognitive load, identified by Hamp-Lyons and Condon, that the assessment of portfolios places on readers. Here, I suggest an alternative method of assessment-the self-revised essay. The self-revised essay requires that students, at the beginning of the semester, write an essay in response to a prompt that reflects a theme that runs through course texts and discussions. Then, throughout the semester, students revisit, reflect on, and revise their essays three more times, with all reflections and revisions taking place in class. The result is a multi-drafted essay, written independently, but informed by course texts, class discussions, and instructor and peer feedback on other essays written for the class. As an assessment tool, it offers the best of both worlds-like the portfolio, it reflects current views of writing, and, like the timed essay, it allows readers to have full confidence that students are the sole authors of their work. Further, it does both without placing on readers an overwhelming cognitive load that might compromise the assessment process.

KEYWORDS: assessment, timed essay, portfolio, reflection, revision, self-revised

As writing has come to be seen over the past fifty years as a social process supported by the interaction of a number of cognitive sub-processes, and writing instruction has changed to accommodate and address this altered perspective, writing assessment has also evolved. Kathleen Yancey identifies three waves of writing assessment over the course of the last five decades, and views these waves from multiple perspectives. In one view, she describes the waves in terms of a shift in the methods through which writing assessment is defined: objective tests (I95O-I970), holistically scored essays (I97O-I986), and portfolio and programmatic assessments (I986-present). However, she acknowledges that these waves could be framed in terms of other shifts and tensions, such as between reliability and validity, assessment by testing experts and by faculty, and assessment taking place outside of and within the context of the classroom (484).

Janine Graziano-King is Assistant Professor of English at Kingsborough Community College, CUNY, where she also serves as Director of the Kingsborough Center for Teaching and Learning. 
Extending the metaphor, Yancey notes that waves in writing assessment can best be described as "overlapping...with one wave feeding into another but without completely displacing waves that came before" (483). One such overlap can be seen in the practice of incorporating both timed essay exams and portfolios in the assessment, a practice motivated by the complementary information provided by the two assessment methods (White 34). On the other hand, however, as noted by Liz Hamp-Lyons and William Condon, the inclusion of a variety of texts in a portfolio also has a cost, potentially encumbering holistic portfolio assessment to the point of undermining the assessment process (I80). Here, I suggest a different model of writing assessment — the self-revised essay—which, I argue, captures the best of both portfolio and timed essay assessments.

\section{Timed Essay Exams}

Timed essay exams provide a more valid way to assess writing than did the highly reliable multiple choice tests of grammar and punctuation of the I950s and I960s, which, at best, only indirectly assessed writing ability. However, as is often the case, the tradeoff for greater validity was reduced reliability. Yancey notes that this issue was addressed by such scholars as Edward White, Rickard Lloyd Jones, Karen Greenberg, Lee Odell, Charles Cooper, and others, who pioneered essay tests that used writing prompts, as well as assessment protocols that selected "anchor" papers, provided scoring guides, and implemented methods for calculating "acceptable" agreement among readers (490). The practice of "norming" readings not only increased reliability, but also allowed assessment to be done by experts and non-experts to take place both outside and within the context of the classroom (e.g., for program placement and exit).

Edward White, in "An Apologia for the Timed Imprompu Essay Test," argues for the appropriateness of the timed essay in some situations, but notes its limitations. He points out that the timed essay "restricts the world of the student, who must write under time pressure to someone else's topic and scoring criteria" (36). While the timed essay directly measures writing, it can be argued that the writing it measures is somewhat narrowly defined. In fact, White acknowledges that the timed essay "does define writing as first-draft writing" (36). This definition stands in contrast to a more complex, cognitive view of writing that involves the interaction of a number of subprocesses, such as planning and revising (Cho I66), and ignores the current view of writing as a social process. As such, White concedes that timed essay 
test conditions, which do not allow for collaboration, preparation, or real revision, are inauthentic (36). It could, however, be argued that timed essays are, in fact, authentic, given that many occasions of student academic writing are instances of timed, "first draft" writing (namely, in-class essay exams in courses across the curriculum). But authenticity of writing assessment refers to how well the assessment matches the writing tasks we are preparing students to do beyond the test-any test. It seems to me that in teaching writing, we are teaching students how to go beyond the first draft, and it is this that we should be assessing.

\section{Portfolios}

The shift in direct assessment—from timed essays to portfolios—was motivated in part by the desire to bring writing assessment more in line with current cognitive and social views of writing, and to tie writing assessment more closely to course curriculum. Instead of assessing student writing on the basis of a single piece produced at a single moment in time, portfolios present multiple samples of a student's work in a variety of rhetorical styles that reflect course curriculum. Furthermore, portfolio pieces are drafted, with each draft benefiting from instructor and/or peer feedback. Finally, portfolios usually include student self-assessment in the form of a piece in which students reflect on their work and discuss the criteria they used in selecting pieces that they chose to include in their portfolios. Such reflective self-assessment invites students to become active participants in their own learning.

As in timed essay assessment, portfolio readers are normed in order to increase assessment reliability, so that assessment need not be done by assessment experts. Finally, portfolio assessment can be used to assess student outcomes at both the classroom and program levels.

\section{Timed Essays vs. Portfolios}

White makes that point that, "No assessment device is good or bad in itself, but only in context" ("An Apologia" 34), and what defines that context is the information we need to know and how we will use it (32). With this in mind, we can compare timed essay and portfolio assessment in terms of the information each yields and the contexts in which each would be appropriate. 
White argues that there are situations where the information needed is minimal and in such situations, the timed essay is entirely appropriate. He offers, as an example, using timed essays to place students into freshman English, where all we need to know is whether students are prepared to learn to write at the college level (33). It is in Freshman English that they will learn how to write at the college level; that is, they will learn how "to use sources intelligently to support-not substitute for-their own ideas, discover and revise complex arguments, show some depth of understanding of a topic, and understand the discourse community of a particular field" (34). Timed essays, however, cannot tell us, at the end of a college writing course or program, the degree to which students have learned to do this because they do not allow students the opportunity to demonstrate these abilities. On the other hand, portfolios, with drafted essays that allow students to draw from sources and to reflect on and revise their work, can. Therefore, portfolios are the more appropriate measures of student achievement in college-level writing, as defined by White.

If this is the case, why do portfolios often include a timed essay? If White is correct in his view that the timed essay offers only minimal information about student readiness and little about student achievement, what other information could the timed essay possibly contribute beyond the information available through the portfolio? White argues that timed essays assure readers that "the student sitting and writing is the author of the work to be evaluated," and it is this that motivates the practice of including timed essay tests in portfolios (34).

\section{Including Timed Essay Exams in Portfolios}

At Kingsborough Community College, developmental English and ESL courses address both reading and writing, reflecting the view that the two are inextricably connected, and course curricula are sometimes focused on a course theme. For example, one semester, my ESL students and I explored the theme of trust through reading and discussing stories where a character's trust is betrayed. That semester we read Anita Shreve's The Pilot's Wife, which focuses on trust between a husband and wife; Mark Haddon's The Curious Incident of the Dog in the Night-time, where a breach of trust damages the relationship between a teenager with Asperger's Syndrome and his father; and S. E. Hinton's That Was Then, This Is Now, where a teenager betrays his best friend's trust to do what he believes is right. Reading and discussing these texts provided the class with opportunities to think about the notion 
of trust by exploring breaches of trust motivated by a variety of reasons and through a variety of relationships.

At the end of the semester, reading ability is assessed through shortanswer departmental reading exams given at each level, and writing ability is assessed through portfolios. Portfolios consist of two drafted essays with a minimum of three drafts each, a letter or essay in which students reflect on themselves as writers, and an in-class, end-of-the-semester, timed essay exam. One week in advance of the essay exam, students are given a reading, which they are free to discuss, annotate, and bring with them to the exam. The exam asks students to respond to one of two essay prompts based on the reading, and students must cite from the reading to support their responses.

Portfolios are assessed by instructors who are normed in order to increase assessment reliability. Norming is especially important, as the purpose of portfolio assessment is not only to determine whether students' work meets course objectives, but also to inform decisions about students' next placement within the developmental sequence. In addition, when assessing portfolios at the end of each semester, instructors pair up with "portfolio partners" and exchange class portfolios so that instructors' assessments are not biased by background knowledge of their own students.

Although readers respond to a single rubric and are expected to assess the portfolio as a whole, it has been my experience that such holistic scoring is extremely difficult. Hamp-Lyons and Condon, who surveyed portfolio readers at the University of Michigan, discuss the difficulty of holistic portfolio assessment: "Multiple texts, unless texts are so close in kind and quantity that they are virtually identical, inevitably force readers to consider one text in the light of another, to weigh one against the other, and to make a decision that, while representing a judgment about the whole portfolio, is grounded in a weighing of the parts, rather than in a dominant impression of the whole. In such cases, decisions become harder, not easier" (I80). As a result, they found that readers may look for short cuts to decision making-short cuts that often involve not considering all parts of the portfolio. Hamp-Lyons and Condon consider this strategy for reducing the cognitive load of holistic portfolio assessment as "a human trait" (I83), and not as indicative of a lack of training or professionalism. I found their view comforting, since I have to admit to taking such a short cut, myself. In my case, the short cut was motivated by a lack of confidence in all but the timed essay.

My lack of faith in the drafted essays and reflective writing stems from a number of concerns. First, for none of these writing samples is sole authorship by the student guaranteed. Even if we dismiss, for the sake of 
discussion, the very real possibility that students sometimes hand in work that is not their own, sole authorship may be compromised by instructor feedback. Hamp-Lyons and Condon recognized this problem of instructor input, reporting that portfolio readers in their study "were aware of the part they played as instructors in improving their own students' texts, and that this led them to be suspicious when they saw significantly better revised texts than impromptu writing in portfolios from other classes" (I85). Hamp-Lyons and Condon speculated that inclusion of all drafts might solve the problem, but, in my case, it was looking at the earlier drafts themselves, that made the problem salient.

I found that, depending on the instructor, feedback on student drafts can range from scant to ubiquitous; it can take the form of questions for students to consider, suggestions for revision, directives for revision, or, in some cases, rewrites in the handwriting of the instructor (though I realize that this last form of feedback does not necessarily reflect the words of the instructor, as it can instead represent those of the student during instructor-student conferencing). Editing feedback is likewise variable, with some instructors suggesting that students review papers for certain mechanical problems, others identifying each problem directly, and still others actually making the corrections for the students. Variability also exists with respect to when editing comments appear; while most English faculty at Kingsborough refrain from editing until the penultimate draft (except in cases where global errors severely impede understanding), others begin editing comments in earlier drafts.

If instructor feedback on portfolio work raises questions about what students can do independently, variability across sections of a course poses an additional problem. Assuming, as is the case at Kingsborough, that faculty are normed for portfolio assessment, they are presumably assessing student work across individual classes taught by different instructors using the same criteria at the same course level. It seems to me that a student's work can be privileged or disadvantaged when compared to the work of other students taking the same course, depending on the nature of the feedback the student received from his or her instructor. Program directors at Kingsborough are currently addressing this issue through faculty development focused on instructor comments, but given the large number of instructors, both fulltime and part-time, who teach portfolio courses, establishing a departmental approach to feedback presents a real challenge.

Even in those cases where it is clear that instructor feedback is not compromising assessment, portfolio readers can be confident only that 
final drafts do not reflect the work of the instructor; they still do not know the degree to which final drafts-or any drafts for that matter-reflect what students can do on their own. This is not to say that students who are not the sole authors of their essays are necessarily being dishonest. Portfolios reflect a pedagogy that recognizes the social aspect of writing; the notion of "workshopping" essays, and the peer-review and discussion of student papers that is inherent in it, promotes student collaboration. However, students, especially those at community colleges, often need time to become acculturated to the practices and values of academia; they do not always recognize the sometimes subtle distinctions between collaboration and plagiarism. And, unfortunately, I have found that given the high-stakes nature of portfolios and the frustration that often accompanies working through developmental course sequences, some students, in desperation, do at times intentionally resort to plagiarism.

So, every time I faced a portfolio, I found myself reading the timed essay first. I thought that if students could successfully integrate and cite source material (a benefit of the practice of giving students a prior reading) and demonstrate some level of analysis in a coherent and well organized essay under timed testing conditions, then I had no reason to read any further. My decision to pass them was made. I did read the rest of their portfolios, however, so that I could provide more informed feedback that recognized and encouraged each student's strengths and offered suggestions for addressing weaknesses. But the drafted essays did not inform my ultimate decision.

If a student's timed essay did not merit a "pass" on its own, I truly struggled. If instructor feedback was not very directive, I simply trusted that what I was reading was the student's own work, and assessed it accordingly. If, however, instructor feedback was highly directive, I often resorted to comparing first drafts to each other, hoping that first drafts written later in the semester were stronger than those written earlier in the semester, so that I could identify student progress.

Reflective writings did not offer much help. If these are done well, authorship is not likely to be questionable, but it has been my experience that most students in developmental courses struggle with these pieces. Most of the reflections I have read reflected less on the students' own work and more on the English courses students were taking at the time-an issue that program directors at Kingsborough are currently addressing through faculty development focused on preparing students to write and revise reflective pieces-but I believe that the metacognitive skills needed for reflection and self-assessment make these activities particularly challenging for students in 
developmental courses. In other cases, real self-assessments were not always supported by student work. Even White, arguing for grounding assessment in reflective writing in "The Scoring of Writing Portfolios: Phase 2," notes that "the reflective letter is a genre itself, and a difficult one to do well; thus it adds a new burden to both the preparation and scoring of portfolios" (594).

In short, with the timed essay, the two drafted essays, and the reflective piece, I found that portfolios often offered "too much information" and "not enough information" at the same time. Taking to heart White's admonition that "it is wasteful and intrusive to gather more information than we can well use" ("An Apologia" 33) and Brian Huot's call for the development of new procedures for writing assessment that link "instruction and practical purposes with the concept of measuring students' ability to engage in a specific literary event or events" (56I), I suggest a method of assessing student writing that captures, I believe, the best of portfolios and timed writing exams-the self-revised essay.

\section{The Self-Revised Essay}

The self-revised essay is an essay that students write, reflect on, and revise over the course of a semester in class and without direct feedback. Students write the first draft in the first or second week of the semester and then revisit it three more times as the semester progresses. Each time they revisit it, they read their prior draft and write a short reflection, discussing the changes they wish to make; they then write a revision. All of this work-both reflection and revision-takes place in the classroom. At no time do students take their work home with them. Instead, the instructor collects their work and holds it until the next reflection/revision; he or she may or may not read these drafts, but in any case, does not comment on them. In this way, sole authorship is ensured, and, across course sections, student work that is to be assessed is neither privileged nor disadvantaged by direct instructor feedback. It is important to note that while instructors do not provide direct feedback on the self-revised essay, direct feedback is provided to students on the other drafted essays they write over the course of the semester, allowing instruction to be targeted to student needs and providing students with concrete examples from which they might make generalizations about strengths and weaknesses in their writing. 


\section{The Self-Revised Essay Prompt}

As noted earlier, developmental English and ESL courses at Kingsborough address both reading and writing, and often a common theme links texts to each other and to writing assignments. Theme-based writing courses foster integrative learning in its broadest sense-that is, deep as opposed to surface learning - a central goal of a liberal education and the impetus for the current review of General Education curricula across college campuses nationwide. From the perspective of writing pedagogy, the practice of adopting a course theme is motivated by an underlying assumption about writing ability; namely, that it is tied to contextual knowledge and should not be defined in terms of isolated skills.

The adoption of a course theme is crucial to the self-revised essay, as it is the theme that connects coursework to the initial writing prompt and offers students the opportunity to develop and support their ideas through readings and class discussions throughout the semester. The self-revised essay prompt is designed with the theme and course texts in mind, and touches on issues that allow students to use their personal experiences as well as course texts as sources.

In this way, the essay can develop over time. When students write their first drafts early in the semester, they will not have read any of the course texts and have not yet explored the theme in class discussions. Since their thinking has not yet been informed by course content, their responses draw only from their current knowledge base-most likely, personal experience. By the next draft, they would be reading or have read at least one of the themebased texts and will have participated in class discussions around the theme, though not directly related to the prompt. At this point, they will have more to draw from, and at each reflection and revision session, the instructor encourages, but does not require, students to consider course discussions and course text(s) in expanding, developing, and supporting their response to the prompt. In fact, in piloting the self-revised essay, my colleague, Ann Del Principe, and I have found that, invariably, students choose to cite at least one of the course texts as they revise without being required to do so. We feel that this choice reflects students' developing understanding of the nature of college writing.

Reflection and revision occur two more times as the semester progresses; at these later revision sessions, students are encouraged to bring in drafts of other essays - those that the instructor has commented on-to look for recurring suggestions for strengthening their work through revision and 
editing, and to see if these suggestions might be relevant to their work on the self-revised essay. In this way, students are encouraged to extrapolate from instructor comments and begin to identify aspects of their writing that require particular attention. By the last revision at the end of the course, students should be able to offer a more sophisticated response to the prompt in an essay in which ideas are more elaborated and better supported than they were in the initial draft, and developing internal criteria for college writing are reflected

Ann Del Principe and I field-tested the self-revised essay in her ENG 9I course-our first level of developmental English. In that course, students read a number of texts and saw a film in which the central themes of The Odyssey are explored. They began with Homer's The Odyssey, and additionally read Tennyson's Ulysses, Eudora Welty's Circe, and Charles Frazier's Cold Mountain; they also viewed the Coen Brothers' film Oh Brother, Where Art Thou? In this way, students saw the story of The Odyssey explored in different contexts, thereby encouraging analysis, comparisons, and consideration of the theme from multiple perspectives. In this course, students were given the following prompt for their self-revised essay:

Many of the texts we will read this semester have a character that grew up without one or both of his or her parents. Before we begin to read these texts, I want you to reflect on your own thoughts and experiences with this situation. What do you think are the effects on a child of growing up without one or both of his or her parents?

As you answer this question, feel free to share and reflect on real life experiences and/or observations. In addition, think critically about the question. Do you think the effects are different if it is the mother, rather than the father, who is missing? Do you think it matters at what age the child loses his or her parent? Do you think there are other environmental factors that influence the effects this situation could have on a child?

The first and final drafts of one student's self-revised essay, written in response to this prompt, appear with permission in Appendices A and B, respectively. In the first draft, as expected, the student draws only from her own experiences in responding to the prompt. However, by the final draft, written at the end of the semester, she references course texts to illustrate her points. 


\section{The Self-Revised Essay Process}

Ann and I have been working with the self-revised essay in two different courses-ENG 9I, as noted above, and ESL o9 (intermediate ESL) - over two semesters. Each time, we have tinkered with the process a bit. Thus far, we have found that it works best when each revisit to the essay extends over two, two-hour class periods, so that students have enough time to read, reflect, and revise. This is especially important as we feel that students need sufficient time for the reflective piece, which allows them to assess their work to date and articulate plans for revision.

While the self-revised essay was initially motivated to improve assessment, I believe the practice of allowing students to reflect and revise in class benefits students and is pedagogically sound. First, offering students a block of class time for reflection and revision has the practical impact of giving them uninterrupted time to work. For the many students who work long hours and/or are raising families while pursuing their degrees, quiet time to work is a luxury; these students are often hard-pressed to find such time outside of class, and I have read a number of unsuccessful revisions written by talented students who were clearly just pressed for time. For others, who have not yet developed the study skills necessary to be successful in college, in-class reflection and revision time serves to model the kind of opportunity for sustained writing that students need to create for themselves outside of class.

In addition, by carving out class time for reflection and revision, we underscore, in a very real way, the value we place on process. Further, since students work on the self-revised essay over the course of the semester, each new reading and discussion offers the opportunity for further exploration of the theme; fresh ideas and perspectives are continually available to inform each revision. In this way, students may experience revision as a process of development rather than, as is often the case, simply seeing it as rewriting, again and again, the same paper, based on texts they have long since read and discussed.

Practically speaking, we have found that it is more efficient for students to write and revise on computers; so, when students are scheduled to work on self-revised essays, the class is held in a computer lab. For convenience, we have found it useful to have students work on a floppy disk that is labeled with their names; disks are then collected at the end of each self-revised essay session and returned to students at the following one. 


\section{The Self-Revised Essay: What Information Can It Provide?}

I believe that the self-revised essay, as an assessment tool, captures the best of both timed essays and portfolios. Like timed essays, self-revised essays assure readers that students are the sole authors of their work. There is no question of influence from the instructor's direct feedback or of any academic dishonestly due to "over-collaboration," whether intentional or accidental. Self-revised essays are also, in a way, "timed" since all work is done during class periods; they are, however, a more authentic assessment tool because students have multiple opportunities to revise their work and because self-revised essays are informed by course texts, discussions, and instructor and peer review on other essays. Therefore, the self-revised essay does not totally isolate students from any social interaction that may inform the development of their thinking and writing; it only restricts direct feedback on the essay itself.

Like portfolios, self-revised essays allow for student self-reflection. However, reflection, as it is practiced in the self-revised essay, is focused and concrete. Although they might consider their work on the self-revised essay in light of instructor comments on drafts of other essays, students are not asked to write a reflection on their writing in the abstract, or across multiple pieces, or on themselves as writers-but on a particular piece at different points in time. This activity allows reflection to be scaffolded-an approach that may be particularly appropriate for students in developmental courses.

Further, like portfolios, self-revised essays offer students opportunities to integrate and cite textual support as they develop their ideas and arguments; in fact a student might completely change his or her thesis in response to course texts and discussions.

On the other hand, self-revised essays differ from portfolios in that they offer readers only multiple drafts of a single essay, while portfolios offer readers a range of genres on which assessment can be based. HampLyons and Condon, however, challenge this assumption about portfolios by considering two underlying assumptions: "first, that writing will vary from genre to genre, and second, that a portfolio will necessarily contain texts of more than one genre" (I8I).

Regarding the first underlying assumption, Hamp-Lyons and Condon point out that while the demands on the writer's skills vary from genre to genre, "it does not follow that a student who will do well on one will do poorly on the other. If writing quality does not vary from one genre to another, there is no assessment argument for including multiple genres (though 
there may be pedagogical reasons), since they do not actually broaden the basis for the decision. And if writing quality does vary from one genre to the other, then the decision is harder" (I8I). In fact, however, they found that for readers, "the influence of multiple genres, when they occurred, seemed to be minor" (I8I). Instead, differences were more likely to be found between the revised texts and the timed essays, which were often of the same genre, than between revised essays of different genres.

Turning to the second underlying assumption, Hamp-Lyons and Condon argue that if it is the students who select the contents of their portfolios, "there is no guarantee that genres will vary" (I8I). They report that at the University of Michigan, they required that one portfolio essay be an argument, and found that most students' second essay was also an argument. It was this practice that prompted them to later require that students include a reflective piece (which is inherent in the self-revised essay as well). Therefore, it is unlikely that the range of genres in portfolios is greater than in the self-revised essay.

Self-revised essays, then, give us information that we can get from portfolios only when they include timed essays-that is, from the two types of assessments taken together. In short, self-revised essays can tell us what students can do on their own with opportunities to reflect, plan, and revise, and with the support of theme-based discussions and texts.

However, there is some information that timed essays and portfolios offer separately that self-revised essays do not. Unlike the timed essay, the self-revised essay does not give us much information regarding what students can do in a timed, high-pressure situation. And unlike portfolio assessment, the self-revised essay does not offer information regarding students' selection of their own best work, nor does it offer information regarding how students respond to direct feedback from a more experienced writer-their instructor.

On the other hand, the self-revised essay might offer information that is not available through either timed essays or portfolio assessment: a glimpse into what students have internalized through the course of the semester. While students are not receiving direct feedback on the self-revised essay, instructors and peers are commenting on drafts of other essays that students are writing for the course. From the first to final draft of the self-revised essay, we can look for evidence that students have taken something from this feedback and the course in general that they were then able to apply to the self-revised essay. I see this information as infinitely more valuable than knowing how students write under pressure, which does not reflect what we 
are teaching in our courses. I would also argue that it is more valuable than knowing which pieces they feel represent their best writing, especially since information on student self-assessment is available through the reflective piece. Most importantly, however, I think that assessing a student's ability to take what was learned from the course-that is, from texts, discussions, and instructor and peer feedback on other course essays-and independently apply it to the self-revised essay, is more valuable than knowing how they respond to direct feedback because it represents the flexible knowledge that is the hallmark of critical thinking and writing.

An additional potential benefit of the self-revised essay is that because it asks students to draw from their coursework as they revise their responses to the prompt, it is tightly tied to instruction. By making comparisons between first and final drafts, then, the self-revised essay may be useful for course or program assessment, providing information about student outcomes regarding particular course or program objectives. This type of pre- and post-instruction assessment is not new. For example, both William Sweigart and Willa Wolcott compared essays written for placement with those written at the end of the semester by students in developmental writing programs. However, in these cases, the two essays that were compared were independent pieces on unrelated topics. Here, I am suggesting that comparisons might be made between drafts of a single piece of writing that reflects course curriculum. In this way, pre- and post-assessment via the self-revised essay, rather than being behaviorist in nature, instead represents a more complex humanistic-constructivist perspective. In addition, the focus on linking writing assessment to curriculum paves the way for writing assessment that informs teaching, providing the integral link that closes the feedback loop and defines the purpose of the assessment cycle-namely, to improve instruction.

\section{Conclusion}

The self-revised essay, like portfolio assessment, reflects current views on writing as a social process supported by interacting cognitive sub-processes, but also, like timed essay assessment, allows readers to have full confidence that students are the sole authors of their work. The self-revised essay is as valid and reliable an assessment tool as portfolios that include timed essays, and it allows for assessment to be done by non-experts at both the classroom and program level. In addition, as I have suggested, the selfrevised essay may yield information about student learning that can inform course and program development. 
Clearly, research needs to be done to determine whether the self-revised essay lives up to these expectations and what role it might play in the assessment process. I would not wish to see it become another piece added to the portfolio; the problem that readers encounter when facing multiple portfolio pieces does not need to be exacerbated, and, after all, the self-revised essay was motivated to a great extent by the desire to reduce the cognitive load of portfolio readers.

Ann Del Principe and I have compared students' final drafts of the selfrevised essay to their timed essay exams and our findings suggest that self-revised essays may offer a good alternative to the inclusion of timed tests in portfolios. However, depending on the purpose of assessment, the independently written, self-revised essay, with its multiple drafts and focused reflections, could potentially replace the portfolio itself. Here I merely suggest it as an alternative assessment practice and as the subject for future assessment research.

\section{Author's Acknowledgments}

The author wishes to acknowledge Ann Del Principe for her support and encouragement in developing and field-testing the self-revised essay process, for insightful discussions that helped situate the self-revised essay in current theories of writing, and for her comments on an earlier version of this paper. The author is also grateful for the helpful comments of anonymous reviewers and the editors of this journal.

\section{Works Cited}

CCCC Committee on Assessment. "Writing Assessment: A Position Statement." College Composition and Communication 46.3 (1995): 430-37.

Cho, Younsuk. "Assessing Writing: Are We Bound by Only One Method?" Assessing Writing 8 (2003): I65-9I.

Del Principe, Ann, and Graziano-King, Janine. "When Timing Isn't Everything: Resisting the Use of Timed Tests to Assess Writing Ability." Teaching English in the Two-Year College (forthcoming).

Frazier, Charles. Cold Mountain. New York: Vintage Books, 1998.

Haddon, Mark. The Curious Incident of the Dog in the Night-Time. New York: 
Doubleday, 2003.

Hamp-Lyons, Liz, and William Condon. "Questioning Assumptions about Portfolio-Based Assessment." College Composition and Communication 44.2 (I993): I76-90.

Hinton, S. E. That Was Then, This Is Now. I97I. New York: Puffin, I998.

Homer. The Odyssey. Trans. Edward McCrorie. Baltimore: Johns Hopkins UP, 2004.

Huot, Brian. "Toward a New Theory of Writing Assessment." College Composition and Communication 47.4 (I996): 549-66.

Oh Brother, Where Art Thou? Dirs. Joel Coen and Ethan Coen. DVD. Touchstone Home Video, 200 .

Shreve, Anita. The Pilot's Wife. Boston: Little Brown, I998.

Sweigart, William. "Assessing Achievement in a Developmental Writing Sequence." Research and Teaching in Developmental Education I2.2 (I996): 5-I5.

Tennyson, Alfred. "Ulysses." Victorian Prose and Poetry. Ed. Lionel Trilling and Harold Bloom. New York, London and Toronto: Oxford UP, I973. 4I6-I8.

Welty, Eudora. “Circe.” The Collected Stories of Eudora Welty. New York: Harcourt, I980. 53I-37.

White, Edward. "An Apologia for the Timed Impromptu Essay Test." College Composition and Communication 46.I (I995): 30-45.

_. "The Scoring of Writing Portfolios: Phase 2." College Composition and Communication 56.4 (2005): 58I-600.

Wolcott, Willa. "Evaluating a Basic Writing Program." Journal of Basic Writing I5.I (1996): 57-69.

Yancey, Kathleen Blake. "Looking Back as We Look Forward: Historicizing Writing Assessment." College Composition and Communication 50.3 (I999): 483-503.

\section{Appendix A}




\section{Student's First Draft}

Growing up without one or both parents has many bad effects on a child mainly because if theirs only one parent sometimes its hard for that parent to raise on their own and that in some cases might hurt the child for example theirs many single parents that don't have time for their children they have to work twice as hard sometimes to take care of their family being that theirs only one parent and the child might feel neglected and if this occurs the child may act out by in some cases running the streets, getting into trouble just going down the wrong path due to the absence of either mother are father it doesn't make a difference whose missing . A chilled needs both parents just like it took both parents to make that child so that child would still be effected if the mother is around the father is not are vise versa, but in some cases children are with one parent due to losses maybe one parent past away are left before they were born are when they were to young to remember and even in this case the child would still be effected, so it doesn't even matter how old the child is because if their young they'll realize the absence and as they get older they'll have many questions and concerns some may understand and some may not. Myself for example when I was a child my father was always around and my mother was not he used to pick me up almost everyday and take me to the game room so we can play arcades and shoot pool he was good at that. He would sing to me while he played his guitar I had so much fun with him hr was my only parent at the time but my aunt was my guardian then times past and I started seeing less of him I didn't understand why he disappeared and when I asked questions all I got was lies I dint know what to believe but then my mother came back from Grenada and now its just me and her which was kind of hard because I was so used to being with my dad so as I grew my sister and I just wasn't obedient to my mom because she was still a stranger to us but as I matured I'm on the right path but I but I still think of my father. Sometimes I think I'm to old to even care anymore but as I write this essay I know that I still do. Feeling neglected, Disappointed, Betrayed, and Hurt I think are the effects on a child growing up without one or both parents because that's how I feel. 


\section{Appendix B Student's Third (Final) Draft}

\section{The Effects on a child growing up without one or both parents}

Have you ever wondered how growing up without one are both parents effects the life of a child? If you have please allow me to give you some insight as well as evidence from two novels I've read this semester. The Odyssey by homer and Cold mountain by Charles Frazier which shows the effects on a child growing up without one or both parents.

Growing up without one or both parents has many negative effects on a child. I don't think theirs any positive effects that's my opinion. Mainly because if theirs only one parent sometimes it's hard for that parent to raise a child on their own and this may hurt the child, for example theirs many single parents that don't have time for their children. They have to work twice as hard at times to take care of their family being that their the only parent. The child may feel neglected and if this occurs the child may act out in some cases by running the streets, getting into trouble just going down the wrong path due to the absence of either mother are father it doesn't make a difference who's missing.

A child needs both parents just like it took both parents to make a child. The child would still be effected if the mother is around, the father is not are vise versa, but in some cases children are with one parent due to losses. A parent may have passed away are left them while they were still a baby. In this case the child would still be affected because little girls and boys need to learn about certain things. Even though they can learn from others it's better if they learn from their parent or parents.

The novel Cold Mountain by Charles Frazier for instance mentioned a young girl by the name of Ruby whom lived with one parent her father, Stobrod due to the loss of her mom. In the chapter Verbs, all of them tiring on page 8I the last paragraph shows us the negative effects of this child growing up without one or shall I say both parents because her father was hardly ever around. Instead of teaching her how to read and write he was out drinking with his friends leaving her alone days at a time.

This parent neglected this child were as instead of learning how to read Ruby had to learn to survive on her own at such a young age. On page 85 states that at present Ruby is not sure how old she is, being that her father never kept track of her birthday she believes herself to be twenty-one years 
old. I know this child is hurt over the fact of not having her parents, she may not show it like many children as well as adults because we may try to block it out but when were alone and we remember it hurts a lot. It doesn't matter how old the child is they'll realize the absence as they grow and as they get older they'll have many questions and concerns some may understand and some may not.

Myself for example when I was a child my father was always around and my mother was not. My father used to pick me up almost everyday from home and take me to the game room so we can play arcades and shoot pool he was good at that. He would sing to me while he played his guitar. I had so much fun with him he was my only parent at the time, and my aunt was my guardian. Then times past and I started seeing less of him I didn't understand why he disappeared, when I asked questions all I got was lies I didn't know what to believe.

Then my mother came back from Grenada and now its just me and her which was kind of hard because I was so used to being with my dad so as I grew my sister and I just wasn't obedient to my mom because she was still a stranger to us but as I matured I'm on the right path but I but I still think of my father. Sometimes I think I'm too old to even care anymore but as I write this essay I know that I still do. Feeling neglected, Disappointed, Betrayed, and Hurt I think are the effects on a child growing up without one or both parents because that's how I feel.

Also In the book the odyssey by homer shows evidence of my opinion of the effects on a child without a parent in this case the absence of a father figure. Telemachus son of a king named Odysseus who went away to fight in the Trojan War, was effected by the fact that his father wasn't around. In book I line 242 Telemachus talks of his father to the war goddess Athene he say's "He has gone were he can not be seen or found and to me has left nothing but sorrow and tears, not is it only on his account that I am sighing and grieving for the gods have gone on piling other troubles on my head". Odysseus never got the chance to show Telemachus how to be a man and stand up for himself so now there wereio8 men known as suitors that's taking his palace. If the protector is gone who's left to protect the home, meaning if the father is gone who has to protect the home in this case it would be Telemachus he's the only son, but he doesn't know how because his father wasn't around to show him which is causing him a lot of distress.

These are the effects on a child growing up without their parent or parents it may cause a lot of troubles in the child's life as they get older. I believe that both parents need to be in their child's life no matter what or at 
least one. Evidence shown from the characters Ruby from Cold Mountain by Charles Frazier, Telemachus from The Odyssey by Homer and myself all proves the negative affects growing up without one or both parents can have on a child. Which I think supports my opinion on why I say a child growing up without one or both parents has negative effects. I don't think a child adult should feel neglected, disappointed, betrayed or hurt. It takes a village to raise a child so imagine a child that doesn't have anyone. 


\title{
The Economy of Explicit Instruction
}

\author{
Don J. Kraemer
}

ABSTRACT: The risk posed by explicit instruction in composition is that the reduction of writing to stock moves and effective devices may diminish the writer's agency and guarantee reproduction of the teacher's. The advantage of explicit instruction is power: overt and recursive attention to selected strategies can help students imagine the public agency the instruction itself may temporarily suspend. This study argues that growth in student writing can follow from replacing problem-solving assignments (based on the problem-solving strategies found in Freakonomics) with rhetorical-analysis assignments. In this latter kind of assignment, the four features of explicit instruction that this study found empowering are (I) paying attention to how published writers frame problems; (2) labeling the framing move as a rhetorical design on readers; (3) weighing the effects of such designs on readers; and, in a rhetorical analysis of Freakonomics, (4) rewriting an already-framed problem. Such instruction is necessarily preliminary to, but also part of, reflective inquiry into the ethics of the conventions, practices, and aims of teaching and learning academic writing.

KEYWORDS: explicit instruction, economic metaphors, rhetorical analysis and framing, ritual.

\section{The Practical and the Human}

In the March 2007 issue of The Council Chronicle, the article "What Is College-Level Writing?" revisits an old question. To answer this question, the author, Amy Bauman, interviews several compositionists, one of whom, Patrick Sullivan, explains why the question remains important. The question of what college-level writing is still matters, Sullivan says, because how we answer that question "'determines so much of what we do"' (8). This claim seems exactly right. He goes on to say, however, that "'practical reasons' - 'what we do' [emphasis added] —-'are secondary to human reasons," which Bauman reasonably interprets to mean "the development of the individual" (8). Although this interpretation is reasonable, it does not explain how "'human reasons"" differ from the practical. The "practical reasons"” of figuring out "'what we do," moreover, are not only different from "human reasons"; they are "secondary."” But why practical reasons are secondary is also unclear and, for teachers of writing, troubling. It is troubling to think, that is, that "the development of the individual" might

Don J. Kraemer works at California State Polytechnic University, Pomona, and is currently at work on two writing projects: an analysis of the rhetorical caginess in Lincoln's Second Inaugural Address and a study of generative defensiveness in student writing.

(c) Journal of Basic Writing, Vol. 26, No. 2, 2007 
inform, or be primarily related to, our inquiry into what we do for, to, and with our students.

If practical reasons are distinct from human reasons-and let us concede that deadlines are different from death-those practical reasons are not necessarily secondary. They may be essentially entangled with what we choose to call the "human" - the very means by which the human is inferred, embodied, voiced. In our everyday lives as teachers of writing, we compose the human with practical considerations: what texts (if any) do we assign and why? What writing assignment or sequence of assignments works best-and on what basis do we make that evaluation? Toward what revisionary ends do we pitch our comments on this particular paper by this particular student at this particular point in the term? If we do not spend as much time on style and voice as on invention and arrangement, why not? These practical considerations are not necessarily identical with all that is human, but they are in dialogue with mortal matters. Each of us has just so much time to help each student in each of our classes develop something - practical habits, skills, attitudes_of value.

One interesting question raised by the relation of the practical to the human is how explicitly to direct students' human capacities into practical forms. I see one version of this potentially problematic relationship adumbrated in Doug Hesse's candidate for what college-level writing should be: it should be, as Bauman quotes him, “'the ability to contribute to ongoing debates or discussions in ways that reflect both the writer's understanding of others' perspectives (what has been said before and what is being said now) and of current rhetorical situations. It's the ability to adapt to audiences and purposes'" (8). As I understand Hesse's answer, to be able to join a discussion, to understand what-others-have-said-and-are-saying as a perspective, and to make appropriate responses that keep the discussion going are constituent features of college-level writing. And insofar as these features can be found the world over, in places where college-level writing does not happen, in oral as well as in literate cultures, these features are human.

I see the practical - and the problem its relation to the human raises-in what Hesse goes on to say as he completes his answer: "the more important conversation focuses on ... the types of real-world writing that college students and graduates need to be able to do. 'How do those kinds of writing relate to writing in vocational/professional, civic, and personal spheres?'” (8). The topic of relations among kinds of "real-world writing" may be "the more important conversation," I think, because this conversation aims to find out what our instruction can do for our students. It is a conversation 
that will help us answer, in other words, the question of why we would care to define college-level writing in any particular way. But even more, because it is a conversation in which we hold a far-more privileged position than most of our students-we may have long and wide-ranging experience with workplace writing and civic action, we may have studied the relations of varieties of academic discourse to other discourses, and in any case we may feel it is our job to care about this conversation-we have to decide how to teach these future-oriented relations to our students.

Along with this practical question of how explicitly to teach these relations, there is the practical question of which of the many relations to realworld writing — " "vocational/professional, civic, and personal spheres"”-to feature. There is much to choose from. Which emphasis is practically best or humanly right? Although there may be sharp disagreements among us not only on what college-level writing is but also on how to help students achieve that level, we agree it is important to keep this conversation going. This agreement explains why most teachers of writing make their pedagogical choices a key part of the argument they conduct with their students-argument, I say, and not just conversation, because at least some students will passionately disagree with their teachers' decisions about what to do, the assumptions on which those decisions are based, assessments of what has been learned, interpretations about what next steps to take, and so on.

The remainder of this essay will take up some problems posed by explicit instruction: first, a general sense of the ethical uncertainty explicit instruction poses-the problem of whether to name for students what is important and what they must do (Section II); next, the particular problem of which kind of real-world writing to relate explicitly to academic discourse (economics, in this case, as represented in Freakonomics-Sections III and IV); then, the explicit rhetorical intervention designed to improve the pedagogical shortcomings discussed in Section III (Section IV); and last a reflection on what the limited success of the explicit rhetorical intervention might have to say to us (Section V).

\section{The Economy of the Explicit}

How explicitly to conduct our arguments with our students is at least as salient a question as at what level to set college-level writing. How explicitly directive to be has recently been at issue because of the specter of passive learning, that is, explicit instruction linked "with kinds of rote instruction that have indeed encouraged passivity and drained writing of its creativity 
and dynamic relation to the social world" (Graff and Birkenstein xv). In a critique of such instruction, Barbara Couture points out how device-laden it is, whether the devices be the specific templates found in Gerald Graff and Cathy Birkenstein's They Say/I Say or, more generally, “the rhetorical modes; the five-paragraph theme; the processes of prewriting, writing, and drafting; and perhaps even the techniques of tagmemic analysis, problem solving, brainstorming, or cooking and growing" (4I). The price we pay for such practical devices, Couture suggests, is our humanity: "Devices make things available to us without requiring any investment from us; they reduce human activity to the mere process of acquiring a commodity" (4I). In the economy of learning that is explicit instruction, students are reproduced as consumers, not apprenticed to invention and negotiation.

This educational reproduction must be risked, Graff and Birkenstein argue, because "many students will never learn on their own to make the key intellectual moves that our templates represent" (xv). Graff and Birkenstein's templates encompass generic moves like "the rhetoric of problem-formulation," a move that, research tells us, does improve with explicit instruction (Williams and Colomb 258). The improvement associated with explicit instruction, Joseph Williams and Gregory Colomb argue, is one good indicator that explicit instruction is worthy of our investment. Elaborating the economic metaphor that informs the pro and con sides of explicit instruction, they frame the risk as follows:

Nothing challenges our professional worth more than the charge that we are failing our students, perhaps even doing them harm. Aviva Freedman offers the sobering hypothesis that at best we do students no good when we try to teach them to write by teaching them explicit features, rules, or principles of specific genres. At stake in her claim, however, is more than our self-worth. Were such a claim true, it would challenge how we structure curricula, write textbooks, train teachers, do research-indeed, whether we do some research at all. It would encourage financially-strapped provosts to ask what makes generic courses like first year or advanced composition worth their cost. If on the other hand we act on Freedman's hypotheses and they are wrong, the cost will be borne by our students. (Williams and Colomb 252)

The economic metaphor is deliberate, as Williams and Colomb make clear. Taking "the liberty of reframing [Freedman's] question," they revise “'Is ex- 
plicit teaching of particular features possible at all?" into "'Is the benefit of explicit teaching of salient features worth the cost?'" In an extended modification of this latter question, they break down its economic implications:

Assuming normal conditions of effective teaching (knowledgeable teachers, developmentally-ready students, authentic and meaningful tasks),

When we explicitly teach specific feature [F] in situation $[\mathrm{S}]$, how many students $[\mathrm{N}]$ reap benefit [B] (learning, retention, adaptability, confidence, etc.) at what cost [C] (time, demands on students, knowledge and training required of us, etc.)?

Though this formulation may appear crudely economic, it preserves the question for serious investigation. Freedman predicts that research will show that explicit teaching produces negligible benefits at best and may even do harm. We believe the evidence, both theoretical and empirical, already indicates otherwise, that the harm is illusory and that the benefits are many and exceed their costs. (Williams and Colomb 253)

I admire how frankly the authors admit the economic, the ways in which it must deeply inform how we think about teaching-the persons as well as the things we teach. Consider how this deep information is surfaced by their "formulation": quantity ("how many"), value/worth ("worth the costs," "reap benefit," "negligible benefits," and "benefit"), and risk ("even do harm" and "exceed their cost"), none of which appears to me "crudely economic." Even in its cruder versions, the economic seems to me quite human. Which books to use and what kinds, what kinds of writing to assign and how much - these are ethical questions because every text we assign is a choice imposed on students, a choice made by teachers committing students to something rather than something else. Time and space are severely limited (ten short weeks for a basic writing curriculum that serves all majors at the polytechnic university where I work-and where, year after year, on the basis of the California State University's English Placement Test, over 50 percent of incoming first-year students are placed into non-credit-bearing, remedial writing courses). What would be crudely idealistic would be to write about pedagogy as though these economic considerations were administrative only, as if they were not essentially implicated in teaching and learning. 
Because I do believe these considerations are essentially implicated in teaching and learning, I thought it would make sense (and still think it makes sense) to bring the economic more explicitly into my teaching and into my students' learning. That this explicit focus added value is a point the rest of this essay will demonstrate.

\section{Teaching Freakonomics Rhetorically}

In the fall term of 2005 , my students and I spent some time with Steven Levitt and Stephen Dubner's Freakonomics, the best-selling account of a rogue economist who freakishly solves big problems. As a book representative of contemporary and/or ideal practice in the work of economics, Freakonomics arguably does not quite qualify. Many economists "complain that Levitt and his ilk are so far removed from using meat-and-potatoes economic theory they may as well be practicing journalism" (or at least the "nerds" among them make this complaint, according to Noam Scheiber [3I]). Obsessed with the methodological snazziness of Freakonomics, new Ph.D.s in economics, according to Berkeley professor Raj Chetty, are no longer thinking, “What important question should I answer?"” (Scheiber 28). What it means to answer an important question is itself an important point, so in Section $\mathrm{V}$ below, I will return to it.

Freakonomics may or may not be methodologically flip, but it is exemplary rhetorically. In Donald Schön's well-known terms, Freakonomics acknowledges the fact that problems are not out there in the world waiting to be solved; we, rather, must "name the things to which we will attend and frame the context in which we will attend to them" (Schön 40). The problems that Freakonomics provocatively names and frames, it answers with data and logic, using the power of numbers to separate what is from what is believed, allowing the evaluation of the quality of the reasons for our belief. Its answers tend to keep the problems alive and open-as questions deserving further inquiry-rather than closing them shut. Its answers, furthermore, complicate rather than reaffirm the conventional wisdom (e.g., "But if an adopted child is prone to lower test scores, a spanked child is not. This may seem surprising-not because spanking itself is necessarily detrimental but because, conventionally speaking, spanking is considered an unenlightened practice" [Levitt and Dubner I7I]). And Freakonomics is dialogic, giving voice to the reader's questions (e.g., "How, then, can we tell if the abortion-crime link is a case of causality rather than simply correlation?" [I40]), while also anticipating objections ("Sure enough, the states with the highest abortion 
rates in the I970s experienced the greatest crime drops in the I99os, while states with low abortion rates experienced smaller crime drops. (This correlation exists even when controlling for a variety of factors that influence crime: a state's level of incarceration, number of police, and its economic situation.)" [I4O-4I]).

Freakonomics, then, seemed an efficient solution to the problem of connecting, for students of Basic Writing, the human and the practical, approaching human desires from pragmatic and profitable angles. As Julie Nelson puts it in Economics for Humans, "Understanding that economies are vital, living, human-made, and shaped by our ethical choices can help to improve our decisions-both individually and as a society" (Nelson 3-4; see also McCloskey 4I, 55, 7I, 420). That my students would see the rhetorical contingencies that ground our ideals, would therefore grasp the civic salience of the economic, would put the practical and human into dialectical exchange-this hope was initially thwarted. And it was thwarted not by the students' resistance, as one might expect, but by their enthusiasm. They thought they were being unusually well served by our focus on the economic because, as they put it, it made perfect sense to analyze any human interaction for its underlying incentive structure-to ask always, "What's the deal?"

Once I questioned, peevishly and imprecisely, their capitulation to incentive structures: "Must everything be economic?" A young woman responded, "Of course it's economic; everyone needs a carrot!" To which I, the rather plaintive straight-man, put the question, "But what if you don't need a carrot?" "Then," another student said, "you're a vegetable!"

Although I find that story memorable, it is mainly representative: only Ineeded persuading that carrots were always necessary. Was it unnecessary, then, to focus on the economic, when students already grasped its necessity? Here's another story, one meant to illustrate how we stumbled past the vaudeville of my either-or question and into the pathos of the economic question. Recently in a grad seminar the question arose whether it was ethical to require first-year college students to read Lolita. Some of us claimed that eighteen-year-olds, ready or not, have entered the adult world-and what better place than a college classroom to engage a literate pedophile's eloquent perversions; others claimed that the artfulness of Lolita was secondary to the pain it could cause anyone who'd been abused. The discussion proceeded sincerely but, at best, lukewarmly, until one student declared it "silly." "If eighteen-year-olds can be sent to Iraq," he asserted, his patience about gone, "they can read Lolita." 
What had been lukewarm heated up. Was the student saying that sending young soldiers to Iraq was ethical or unethical? If unethical, was he then saying that if the greater of two unethical acts is common practice, then it was silly at best to worry about the occurrence of the lesser of the two unethical acts? But if assigning Lolita was ethical because it confronted students with the reality of a perspective they needed to understand because the better they understood it, the better they could recognize it to intervene, then by the same logic would assigning hard-core or child pornography also be ethical? If any assigned reading has the potential to upset students, then what compels us to take some risks but guard against others?

What I find interesting is how much this turn animated the students. In quantifying quality, we did not so much reduce quality as relate the question of the ethical to the quantitative question of how much unethical risk is too much, a turn that by exposing values also endowed them with a little more urgency. The question was not whether to assign possibly offensive texts (texts probably ought to violate commonsense and home truths in some way). The question, rather, was what price is not too high to pay: how much unequal treatment of students is not too much, how much sacrifice of the well-being needed to learn is not too much. Since whose well-being matters, this question should be recast as how many students to be sacrificed for the greater good is not too many. If we allow that some young people will get left behind, how many left behind is not too many? Who shall these students be?

The economic imperative, then, coincides with a significant rhetorical imperative: to affect policy by reasoning probabilistically about highly contested issues. That the economic meaningfully overlaps with the rhetorical proved, however, to be educationally insufficient, as I hope to show.

My students engaged the economic in the form of Freakonomics. I say my students "engaged" Freakonomics. "Embraced it" is better. Asked in the fall of 2005 to write with and against Freakonomics - to talk like it but also to talk back to it-students balked. Talk back to it?! They could not, protested my students (would-be accountants, computer scientists, K-6 teachers, and psychologists). Why not? I asked. Because, one student (an engineering major) explained, you cannot argue with facts. Why not? I asked again. Because they're proof! he said. Facts are facts.

As I understood my students, they took facts to be what was beyond question-that which was self-evident or had already been established. Facts, then, either had never been in question or had emerged from an intensive 
process of questioning. That facts had a privileged status was encouraged by Freakonomics' characteristic stance, evident in claims like the following:

- But a closer look at the data destroys this theory. (I2I, emphasis added)

- But a thorough look at the data reveals that the graying of America did nothing to bring down crime in the I990s. (136, emphasis added)

- [W] e are less persuaded by parenting theory than by what the data have to say. (I57, emphasis added)

- [T]he data do a nice job of answering the question that every parent-black, white, and otherwise-wants to ask: what are the factors that do and do not affect a child's performance in school? (I6I, emphasis added)

- The data reveal that black children who perform poorly in school do so not because they are black but because they tend to come from low-income, low-education households. (I64, emphasis added)

- The California data prove .... The data also show .... (I83, emphasis added)

-What kind of parent is most likely to give a child such a distinctively black name? The data offer a clear answer: an unmarried, lowincome, undereducated teenage mother from a black neighborhood who has a distinctively black name herself. In Fryer's view, giving a child a superblack name is a black parent's signal of solidarity with the community. (I84, emphasis added)

These metaphors of speaking data and revelatory data reinforce the belief that facts are proof-for everyone, hence the emphasis on discovery rather than on interpretation. This emphasis has consequences: rendering irrelevant the questions of who looks; of whether there might be more than one way to see; of whether there might be more than one way to interpret what is seen, even for the one person who is seeing; of whether it matters how we listen to what the data have to say.

It is not my intention to deny that, in a given situation, there are statements and numbers that count as facts; it was, however, my concern that my students seemed reluctant to question how Freakonomics' facts should count. My problem, in other words, was whether Freakonomics could be read, could be responded to, more rhetorically.

In his 2003 book Defining Reality, Edward Schiappa argues that most 
people must be socialized out of logical positivism and into rhetorical contingency:

Most people become socialized into an implicit picture theory of language that they never find necessary to challenge or modify; a fixed world, as pictured and "given" through language, is taken for granted. Early language education and socialization avoids the idea that our understanding of the world is relative and contingent .... (62-63)

The "picture theory of language" is referential: as children, we learn that the word "cat" refers to an object that can be pointed to and seen (an animal, an image). Part of such normative socialization into the visual is that we are not encouraged to question how our descriptions are dependent on any particular theory. Although we might wonder about the evidence for Schiappa's claim that most people never find it necessary to modify their picture of a fixed world, most of us probably accept the adjusted claim that our firstyear students have been socialized if not to accept institutionally assigned non-fiction texts as authoritative, as factual, then to regard their meaning as contained, something (such as a thesis at the end of the introductory paragraph, say) that can be pointed to and seen in the texts themselves.

The wording of my 2005 assignment did too little to help students read and analyze rhetorical contingency. Their objective was, in the words of the assignment with quoted material from Freakonomics,

to "question something that people really care about and find an answer that may surprise them," to "overturn the conventional wisdom" (89). Conventional wisdom is something people usually accept because it "“contributes most to self-esteem"” and is "simple, convenient, comfortable, and comforting - though not necessarily true" (90). This definition leads us to where questioning should begin: namely, where the "conventional wisdom may be false-... the contrails of sloppy or self-interested thinking-is a nice place to start asking questions" (90).

You can "see" why this assignment led to responses like the following (the student work here and in Section IV, below, is used by permission):

[December 2005]: Have you ever wondered the true meaning behind things that occur in your life everyday? If you looked into the 
interactions over your day would you be able to sort through the real and fake interactions? Most people are oblivious to the lack of care that people and material items represent. When there is a specific job to be done by either a person or item it is most likely going to loose the sincere care. Therefore grocery stores and Barbie dolls are similar because they both portray something different than what they really are.

By imitating one aspect of a Freakonomics' technique-the reversal of conventional wisdom by yoking together two unlike objects-the fall 2005 papers reproduced, and exposed, what was arguably non-academic about that technique: its "cleverness problem," as one critic has labeled it. This same critic also called Freakonomics "an academic parlor game" (Scheiber 28). Such name-calling is, I think, unfair. If Freakonomics is an academic parlor game, it is not always just that. Parts of it may be gimmicky, however, or (more fairly) can be taken as such: the parts in which the conventional wisdom is less engaged than staged, the parts in which there is no reading of what others have written. There are parts in which there is no explicit attention to the rhetoric of problem-formulation; my assignment prompt unwittingly directed my students to those parts.

\section{Explicitly Teaching Freakonomics Rhetorically}

This reaffirmation that students do read strategically, looking to the assignment instructions for direction, compelled me to give more explicit attention to problem-formulation, or rhetorical framing, the next time around. That attention affected the assignment instructions for the paper on Freakonomics, some of which follow:

Analyze how Freakonomics frames one of its arguments and present an alternative frame no less compelling than theirs. You will need to incorporate and analyze at least four (4) quotations from the particular argument you choose from Freakonomics. Some of the templates from They Say/ISay that should prove useful are those for "Introducing an Ongoing Debate," "Capturing Authorial Action," "Introducing Quotations," and "Explaining Quotations.” Depending on how you critique and analyze the quotations, other templates will also help.... Thanks to Freakonomics' insights into how incentives drive behavior, how information is abused by experts, and 
so on, we can see how elementary-school teachers are like sumo wrestlers, how drug dealers run their business like McDonald's, and how anything that reduces the number of unwanted children also reduces crime rates. Perhaps more significantly, we see the power of principle, for in every freakish comparison, what unites the odd couple is an underlying principle (such as getting more for less or avoiding the stigma of shame). An implication for you, however, is whether the frame that leads you to see a crucial likeness is, at the same time, also deflecting crucial unlikenesses (how, for example, are school teachers importantly unlike sumo wrestlers?).

In preparation for a reading of Freakonomics' rhetoric, we worked with Gerald Graff and Cathy Birkenstein's They Say/ISay, which provides explicit templates for framing, such as "At first glance, teenagers appear to But on closer inspection " (I73). To see skillful framing in action, we read experts trying to define important concepts: Harry Frankfurt on "bullshit," Marita Sturken and Kirk Savage on "memorials," Barry Schwartz and Robert Sapolsky on, respectively, the relations of "choice" and "stress" to "happiness." And to theorize these definitional arguments, we read Schiappa on the distinction between "real" definitions and "lexical" definitions: i.e., "Lexical definitions remind us that the relevant question is not "What is rape?' but 'What shall we call "rape"?'” (6I).

Because I was trying to keep alive the question of whether facts were proof, I directed my students' attention to Schiappa's chapters on legal arguments over the status of the fetus and over the definition of rape in marriage, arguments that foreground the contingency of facts. The following summary from Schiappa illustrates this contingency: it is possible "for two observers to describe the same event in a contradictory manner: 'It was rape' and 'It was not rape.' There is no neutral or theory-independent way to decide whether such behavior 'really is' rape or not, but such a determination may be readily made once one definition or another is taken as prescriptive" (64). One implication that Schiappa derives from taking a definition as prescriptive is that to define is, therefore, already to plead a cause: "Whether we are talking about a group of scientists or the citizens of a community," he concludes, "our beliefs are intertwined with our needs and interests" (66). I pushed the possibility that this claim might apply to a rogue economist as well.

My next explicit intervention was two-fold: to foreground rhetoric and, thereby, to complicate the metaphor of data as entities that speak and reveal. One effect of foregrounding Freakonomics' rhetoric was to reconnect 
the roguishly mute, data-subservient knower with the known. Freakonomics sometimes specifically castigates "rhetoric": "Notwithstanding the [crack gang's] leadership's rhetoric about the family nature of the business, the gang's wages are about as skewed as wages in corporate America" (Levitt and Dubner I03). Yet Freakonomics itself is full of rhetorical devices, devices that perhaps contrast with the rhetoric of numbers:

- Who cared if the crack game was a tournament that only a few of them could possibly win? Who cared if it was so dangerous-standing out there on a corner, selling it as fast and as anonymously as McDonald's sells hamburgers, not knowing any of your customers, wondering who might be coming to arrest or kill you? Who cared if your product got twelve-year-olds and grandmothers and preachers so addicted that they stopped thinking about anything except their next hit? Who cared if crack killed the neighborhood? (II2-epiplexis: use of questions to attack)

- Legalized abortion led to less unwantedness; unwantedness leads to high crime; legalized abortion, therefore, led to less crime. (I39-sorites: a logical chain; note that the authors do not consider whether unwantedness leads to legal and/or culturally sanctioned forms of proving oneself)

- Or will they? Parents must matter, you tell yourself. Besides, even if peers exert so much influence on a child, isn't it the parents who essentially choose a child's peers? Isn't that why parents agonize over the right neighborhood, the right school, the right circle of friends? (I55-prosopopoeia: an absent person is represented as speaking; anaphora: repetition of the same word at the beginning of clauses and phrases)

Complications of the speaking/revealing metaphor are implicit even in many of Freakonomics' characteristic claims:

- But a careful analysis of the facts shows that the innovative policing strategies probably had little effect on this huge decline. (I29, emphasis added)

- So what does an analysis of the ECLS [Early Childhood Longitudinal Study, a project begun by the U.S. Department of Education in the late I99os] data tell us about school-children's performance? (I63, emphasis added)

- The result is an incredibly rich set of data-which, if the right 
questions are asked of it, tells some surprising stories. (I6I, emphasis added)

- How can this type of data be made to tell a reliable story? (I6I, emphasis added)

The data matter, but they require interpretation and analysis, careful analysis. The facts may show, but what they show is probably the case. The data may talk-if the right questions are asked. The data are capable of telling a reliable story, if they are made to. In sentences such as "Now a researcher is able to tease some insights from this very complicated set of data" (I62), data are not garrulous but reticent, requiring a playful courtship_involving people who come armed with certain questions and on the look-out with interest-filled eyes. Note the entanglements in the following: "But this data set tells a different story. After controlling for just a few variables-including the income and education level of the child's parents and the mother's age at the birth of her first child - the gap between black and white children is virtually eliminated at the time children enter school" (I64). The data tell a story that corrects the story we typically tell ourselves. But in this story, can it really be that the gap itself controls the variables, or is the dangling modifier a logical extension of Freakonomics' metaphorical frame, even though by the logic of the world as we know it, the gap could not have controlled itself into virtual elimination? Put another way, is the dangling modifier a symptom of the belief that numbers talk, or are the authors of Freakonomics guilty of the kind of stylistic sloppiness student writers themselves get called on?

Whichever answer one deems better, attention to such questions opens the text to critique. In the following excerpt (from the summer of 2006), the student writer had noticed an interesting piece of language in Freakonomics that introduced one of the sections she was critiquing: "To overgeneralize a little bit" (I75). If I may overgeneralize, eighteen-year-olds right out of U.S. high schools are selectively intolerant of generalizations, especially when that generalizing is done by people their parents' age. For the authors of Freakonomics to generalize, to in fact overgeneralize, and then to add "a little bit" - this not only failed to disarm my student; it got her guard up.

[August 2006] At first glance, because of the way it was framed, [Levitt and Dubner's] argument [that perfect parenting is largely irrelevant], although shocking to most, stands pretty solid; even though it is hard to believe, the way they set up their proof makes it very convincing. But again, after reviewing the text and its so 
called "facts," the argument tends to become much weaker as more and more questions and doubts begin to arise from it. The reason why so many holes can be found in their argument is because of the weak frame they used to support it. Levitt and Dubner, being the "Rogue Economists" they claim to be, use test scores as proof to their argument that "it isn't so much a matter of what you do as a parent; it's who you are" (I75).

Although the writer contradicts herself, calling Levitt and Dubner's frame "weak" after having claimed it "stands pretty solid," she locates this contradiction in Freakonomics itself: "The typical parenting expert, like experts in other fields, is prone to sound exceedingly sure of himself' (I48)? Why should we believe them when they themselves tell us not to believe the experts they so strongly resemble?"

The use of Freakonomics against itself continues as the writer examines its position that what correlates with high test scores for children is not what their parents do but who their parents are. This distinction is the principle that informs the eight "factors that go hand in hand with test scores," of which the writer selects one in particular, "The child's parents speak English in the home." Against Levitt and Dubner, who frame this fact as something parents are, the writer reframes it as an act:

Having parents who speak English in the home is not just who they are, but also it is what they do. There are many parents who speak different languages, and still decide to speak English. For example, my sister speaks English and Spanish. She grew up knowing only Spanish, but now she only talks to her kids in English. This was her decision just like it is the parents' decision to speak to their children in whatever language they want. . . . This is something a parent decides to do... [four more inversions of Freakonomics' distinctions between "is" and "do"]. From these results, one can see that it is not just who your parents are, but also what they do.

Whereas Freakonomics labels the speaking of English in the home as really a matter of who the parents are, this paper relabels the speaking of English in the home as something parents $d o$. While accepting the facts disclosed by Freakonomics, the writer contests the frame-contests, in other words, how the facts are spoken for. Speaking for the facts she knows-that is, the facts she knows have yet to be represented-she reconnects the known with the 
knower, breaking Freakonomics' link between the data and the known. This move warrants her conclusion that "Levitt's and Dubner's framing of their argument isn't good enough to convince me in believing that parenting styles are insignificant when it comes to how smart a child is. There are far too many factors that have been left out of their argument that would have been of use to better convince the reader."

The explicit teaching worked, in my opinion, but at what cost? How should we, in other words, describe the relationship between what my students learned to do and who they were?

\section{Cost-Benefit Analysis}

I will end with the problem formulated by Williams and Colomb and quoted earlier in this article:

When we explicitly teach specific feature $[\mathrm{F}]$ in situation $[\mathrm{S}]$, how many students $[\mathrm{N}]$ reap benefit $[\mathrm{B}]$ (learning, retention, adaptability, confidence, etc.) at what cost [C] (time, demands on students, knowledge and training required of us, etc.)? (253)

Keeping in mind the discussion above and plugging some of its particulars into Williams and Colomb's "formula," we might get the following:

When in the ten weeks available to us in the quarter system we explicitly teach rhetorical framing to incoming first-year students (placed, on the basis of their performance on the California State University English Placement Test, into non-credit-bearing basicwriting classes, despite their self-identified native status in English and demonstrated proficiency, as confirmed by among other things the California High School Exit Exam), all students significantly develop their ability to write analytical papers that will gain a hearing in an academic setting, provided that the instructor spends time explicitly teaching rhetorical framing in the context of the source material to be analyzed - at the necessary expense of other kinds of instruction, other kinds of reading, and other kinds of writing.

My version of explicit instruction made the material available in a certain way - as material designed to have designs on readers, as problems framed to frame readers. This instruction worked, in my opinion- "worked" in the 
sense that it prepared students for first-year writing, which their records confirm. But the question remains whether such intervention, however modestly effective, is worth it.

Such intervention is not worth it if it is not the right thing to do. And it might not be. Williams and Colomb concede that the "particular generic forms" of college and workplace writing come with "ideological commitments and consequences" (262). A focus on policy argument will require different commitments and seek (if not cause) different effects than will, say, a focus on lab reports. Each form has its place. But it is not just form that is at issue; there is also the question of pedagogy. I have to be accountable to my students not only for what I am teaching but for how as well. Above all, what justifies my decision to intervene in - to interrupt, to manipulate-their learning?

My answer has three parts. First, I find congenial Williams and Colomb's hopeful belief that "explicit teaching" may be a "necessary step in the process of empowering students to choose how they participate in the communities they encounter and to what degree they will let that participation define who and what they are" (262; see also Gee 54I). Explicit instruction in these forms will be worth it, in other words, if students learn to reflect on their participation in strategically important (and often new) communities-reflecting on what participation means, on whether and how it might change them.

This hopeful emphasis on choice seems well founded. Whether participation in our "ideological commitments and consequences" conflicts with who our students are and who they wish to become is a question they can better engage and contest, once it has been explicitly laid out and performed. This emphasis, nevertheless, begs the question of what we require students to choose among. The curriculum I have described limits the choices of students who might prefer learning strategies to write more expressively, of students who would rather find information they can spread, of students who desire a non-rhetorical focus on correctness, of students who want to read something by non-whites, non-males, non-academics. Even more generally, this curriculum puts at a disadvantage students who wish to be rewarded for strengths that are not explicitly asked for by assignments such as mine.

Such students (despite having passed out of remedial writing) may well feel left behind, which is why my answer has two more parts, two beneficial features of this experience that serve as partial insurance against the many possible costs: the stylistic reframing of college-level writing as ritual and the value this experience held for students. 
A review of some canonical images from David Bartholomae and Anthony Petrosky's Facts, Artifacts and Counterfacts will help bring these two benefits into relief. Bartholomae and Petrosky represent college-level "reading and writing as a struggle within and against the languages of academic life. A classroom performance represents a moment in which, by speaking or writing, a student must enter a closed community, with its secrets, codes and rituals" (8, emphasis added). They frame this "closed community" as a drama, speaking of the "participation in the play of reading that goes on within the boundaries of the academic community" (9, emphasis added) and of instruction in revision as having students "reimagine the roles they might play as readers and writers" (7, emphasis added). The emphasis on enforced participation surely describes much academic experience.

What if we continue framing the enforced participation in collegelevel writing along these lines-as the dramatic play of ritual? Here is the second part of my justification: If we pursue the implications of "the roles [students] might play" as they redefine participation in communities, we can better address the question of choice: why would anyone want to join this spectacle? Even better: why choose to write this way? I think of my first-year students, seemingly unaware-much too unaware-of how they were letting received wisdom define them and their relation to authoritative discourse. They took Freakonomics' thoughts as revelations, the revelations as facts, the facts as proof. But what if, against their way of taking, we resisted with Kenneth Burke's claim that the "'thoughts' of a writer are not the mere 'revelation,' not the statement of a fact"? What if we act on Burke's claim that the writer's “'thoughts' are the framing of this revelation in ritual. . . The 'thoughts' of a writer are the non-paraphrasable aspects of his work, the revelation and ritual in fusion" (Burke I68-69)?

Here Burke is referring to the aesthetic phenomenon of repeated pleasure, how a song or painting can be experienced repeatedly and yet with increasing rather than diminishing returns. A prose writer's thought is also, however, "revelation and ritual in fusion"; a reader experiences a writer's thought in the moves of her prose: its twisting and turning, its bending and manipulating in response to the reader's needs and activity, its renaming and reframing of the Big Question. A writer's thought is not so much paraphrased as enacted, a claim that pointedly applies to Freakonomics: its thought-which is to say, in this case, its classroom value-lies less in its revelations (as though students could imitate Freakonomics best by repeating its discoveries or declaiming revelations of their own) than in its fusion of 
these revelations in ritual (the shared ways it recognizes and then deviates from the conventional wisdom, ways that students can in turn and with help recognize, imitate, and adjust).

To act as though college-level writing were thoughts ritualistically framed would mean inquiring into how the ritualistic templates of collegelevel writing pattern participation in different kinds of conversation. It would mean making more visible the social nature of these conversations, which are, in Anne Haas Dyson's apt formulation, "new sorts of dialogues with the world" (I52). Based on her observations of young schoolchildren, Dyson concludes that the agency required to enjoin these dialogues is driven not by “'sentence' meaning nor even by 'conceptual' meaning but by meeting, negotiating, or resisting the expectations and conventions of the social goings-on" (I49). If to participate in these social goings-on, these rituals, is to learn to play different roles, then to play these different roles is to act out ways of thinking with different audiences for different purposes.

The Freakonomics' assignment sequence did not ask students to play it safe; it did not ask students to reproduce a single correct answer or to follow a recipe for an essay-length paper. It asked them, rather, to act out some ritualized ways of thinking with an audience different from those they were used to; it asked them to read something challenging and say something back to it and to those in the community it represents. As best I can tell-and here begins the third and last part of my justification-my students did not experience their Freakonomics' role-playing as infantilizing or dehumanizing. Because the rituals associated with No Child Left Behind, such as fill-in-the-blank worksheets devoted to standardized-test content and pre-circumscribed essay formats that are audience-proof, have narrowly limited students' curricular exposure to "new sorts of dialogues with the world," the college-level ritual of examining the rituals we use to make knowledge seems comparatively adult, respectful, substantial, important, interesting, pleasurable, and helpful. If the community that students "must enter" is a community that asks important questions, it is thereby a community students are willing enough to enter. To the degree they are interested in what a community does, the degree they therefore desire inclusion, that community is less closed to them than if they were indifferent to that community's work-or, and this seems to be the case, than if they were ignorant of it. The big question in Freakonomics of whether parenting "perfectly" really matters was for nearly all my students an important question, one they were motivated to answer. 
There appears to be a significant difference, however, between these basic writing students and the doctoral students in economics who inspired Professor Chetty's exasperated declaration: students are not thinking, "What important question should I answer?" (qtd. in Scheiber 28). The difference is not necessarily that first-year students are thinking of such fundamental questions, questions so fundamental that the closer one gets to a Ph.D., the farther one's memory has receded from them. Rather, the difference may be that first-year students are less aware that something as fundamental as good parenting is in question. So while I must acknowledge that my students had incentive to disprove what they found freakish-i.e., the claim that what parents can do makes no difference, only who (or what) parents are makes a difference-it is also the case that explicit instruction played a key role in arousing, if not constructing, their highly motivated desire to "communicate with [the] non-intimates" (Gee 54I) making questionable claims about them and their families.

As such, the curriculum described above helped student writers imagine, as Barbara Couture says a curriculum ought, "how they as persons speaking to other persons might be seen to have merit or worth in the eyes of their chosen audience" (47). The strategy implied by Couture's words is primarily pathetic, not ethical. Student writers generally do not begin with already established ethical appeal (I've heard several colleagues, when "outsiders" ask them what they do, say that they get paid to read bad writing. So much for the ethos a student starts with). For a writer's ethos-his credibility, quality, and value-to have effect, it must be "recognized by others" (Couture 44). Writing that is ethically effective might show the writer's life "as having a purpose in a world of others, as expressing the care and attention for others that will ensure reciprocal care and attention to his or her own singular needs" (47). But how can these qualities be enacted for, and thereby communicated to, "non-intimates"?

Such care and attention, I suggest, is demonstrated when a writer undergoes the expected rituals: framing the problem, naming the big question it raises, renaming what really matters. This imitation of others and essayed immersion in their world are not only the fusion of revelation and ritual (a person performs his respect for what his audience values; his prose embodies the desire to relate his values to theirs); they are pathetic appeals. They are something students can do because of who they are. They are people who desire to join new dialogues about the world. And in choosing to do this, students are choosing less an economy of gains and losses, in which to write one way 
means to trade some other way, than an economy of development, in which one writes to become more like who one wants to be with certain others.

\section{Author's Acknowledgments}

I wish to thank Don Daiker, Professor Emeritus at Miami University, Ohio, as well as Richard Courage, Professor of English at Westchester Community College, SUNY, each of whom gave insightful, helpful feedback to an earlier draft of this article.

\section{Works Cited}

Bartholomae, David, and Anthony R. Petrosky. Facts, Artifacts and Counterfacts: Theory and Method for a Reading and Writing Course. Portsmouth, NH: Boynton/Cook, I986.

Bauman, Amy. "What Is College-Level Writing?" The Council Chronicle I6 (March 2007): I, 8-9.

Burke, Kenneth. Counter-Statement. Berkeley, CA: U of California P, I968.

Couture, Barbara. "Modeling and Emulating: Rethinking Agency in the Writing Process." Post-Process Theory: Beyond the Writing-Process Paradigm. Ed. Thomas Kent. Carbondale, IL: Southern Illinois UP, I999. 30-48.

Dyson, Anne Haas. "Literacy in a Child's World of Voices, or, The Fine Print of Murder and Mayhem." Research in the Teaching of English 4I (2006): I47-53.

Frankfurt, Harry G. On Bullshit. Princeton, NJ: Princeton UP, 2005.

Gee, James Paul. “What Is Literacy?” Literacy: A Critical Sourcebook. Ed. Ellen Cushman et al. Boston: Bedford/St. Martin's, 200I. 537-44.

Graff, Gerald, and Cathy Birkenstein. They Say/I Say: The Moves That Matter in Academic Writing. New York: Norton, 2006.

Levitt, Steven D., and Stephen J. Dubner. Freakonomics: A Rogue Economist Explores the Hidden Side of Everything. New York: William Morrow, 2005.

McCloskey, Deirdre N. Knowledge and Persuasion in Economics. Cambridge, UK: Cambridge UP, I994.

Nelson, Julie A. Economics for Humans. Chicago: U of Chicago P, 2006. Sapolsky, Robert M. Why Zebras Don't Get Ulcers, $3^{\text {rd }}$ ed. New York: Henry Holt, 2004. 
Savage, Kirk. "The Past in the Present: The Life of Memorials." Reading Rhetorically: A Reader for Writers, $2^{\text {nd }}$ ed. Ed. John C. Bean et al. New York: Pearson Longman, 2005. 322-30.

Scheiber, Noam. "Freaks and Geeks: How Freakonomics Is Ruining the Dismal Science." The New Republic (April 2, 2007): 27-3I.

Schiappa, Edward. Defining Reality: Definitions and the Politics of Meaning. Carbondale, IL: Southern Illinois UP, 2003.

Schön, Donald A. The Reflective Practitioner: How Professionals Think in Action. New York: Basic Books, I983.

Schwartz, Barry. The Paradox of Choice: Why Less Is More. New York: Harper Perennial, 2005.

Sturken, Marita. "The Wall, the Screen and the Image: The Vietnam Veterans Memorial." Making Sense: Essays on Art, Science, and Culture, $2^{\text {nd }}$ ed. Ed. Bob Coleman et al. Boston: Houghton Mifflin, 2006. 484-504.

Williams, Joseph M., and Gregory G. Colomb. "The Case for Explicit Teaching: Why What You Don't Know Won't Help You." Research in the Teaching of English 27 (1993): 252-64. 


\title{
News and Announcements
}

\author{
CALLS FOR PAPERS
}

\section{Race and New Media: A Conference}

May 3, 2008, New York City College of Technology, Brooklyn, NY

We are interested in papers that deal with any aspect of the relationship between "race" and "new media." We're interested in questions like the following: Does race work differently in the "new" media than it did in the "old" media? Network news, for instance, was widely derided as a nearly diversity-free zone. Is the blogosphere different? How do video games, blogs, chat rooms, and other forms of "new" media and "digital" or "virtual" spaces construct or reflect notions of race? What kinds of "new" identities and/or communities exist in these "new" digital spaces? How is new media being used to make connections, to empower communities, and/or to control, colonize, or dominate them? In other words, are there digital forms of "cultural" imperialism? Feel free to propose papers on any of these topics, or to invent your own!

Submit proposals to: raceandnewmedia@gmail.com by February I, 2008.

\section{Inevitable Intersections: Writing at the Crossroads of Public and Private Discourse in the $2^{\text {st }}$ Century}

2008 Annual Conference of the SUNY Council on Writing April 25-26, 2008, Stony Brook University, State University of New York

In the teaching of writing, the notions of the public and the private invariably intersect. Private or personal writing from our students becomes public when it is shared with the teacher, the writing class, or online. We intend to consider in this conference the meanings and implications of this intersection of public and private discourse. We invite presentations that discuss the relationship between writing and all manner of discourse in terms of the the evolving and expanding grounds of our profession, presentations that explore writing in terms of the intersections of public, private, and academic writing, and presentations that connect academic, public, and private writing to social and political issues both within and outside of academia. We invite papers, workshops, and roundtable discussions that address these and related concerns. 
We are especially interested in proposals on the following topics:

- The role of "the personal" in writing and/or in the writing classroom

- The role of "the public" in writing and/or in the writing classroom

- Public and private discourse as they intersect in writing and/or in the writing classroom

- Public and private discourse across the curriculum and/or within the disciplines

- Reading and writing for personal enrichment-and/or pleasureversus reading and writing for public versions of same

- The role of creative writing across the curriculum and within the disciplines

- Political, social, and economic aspects of the status of writing-program faculty

- Interplay of controversial political, social, and economic issues within the writing classroom.

Proposals for both individual and panel presentations are welcome. Please send 250-word abstracts for 20-minute papers or 500-word abstracts for 8o-minute sessions to Cathleen Rowley carowley@notes.cc.sunysb.edu or Patrizia Benolich at pbenolich@hotmail.com by March I, 2008.

\section{Thomas R. Watson Conference: "The New Work of Composing"}

October I6-I8, 2008, University of Louisville, Louisville, KY

What is the new work of composing in the midst of the rapidly changing technologies and communicative forms that characterize contemporary life? We invite proposals for any topic related to the conference theme, including:

- How do new technologies change the ways we understand the work of composing?

- How do access, materiality, or economics affect composing within and outside the university?

- What are relations between new and old media, between textual, visual, and aural modes?

- What are our responsibilities as teachers, scholars, practitioners?

- Where do we locate disciplinary identity? 
Plenary Sessions will include "New Perspectives on Technology, Media, and Communication" with Andrew Feenberg, N. Katherine Hayles, and Mitchell Stephens; "Access and Agency" with Valerie Kinloch and David Kirkland; "New Forms of Textuality" with Janet Murray, Matthew Kirschenbaum, and Richard Miller; "Text and Image" with W. J. T. Mitchell, Diana George, and Anne Wysocki; and "The New Work of Composing: A Roundtable on Teaching, Scholarship, and Administration" with Jonathan Alexander, Cheryl Ball, Scott DeWitt, Bump Halbritter, Charles Kostelnick, and Andrea Lunsford. Special Presentation: Paul D. Miller; aka DJ Spooky.

We welcome scholarly papers and new forms of scholarship, including videos, sound essays, installations. We encourage you to think creatively about the new work of composing.

\section{Deadline for Submissions: March 3, 2008.}

For guidelines on submitting proposals, please consult our website: www.louisville.edu/conference/watson

For more information, please e-mail us at watson@louisville.edu or call us at 502-852-0504. 


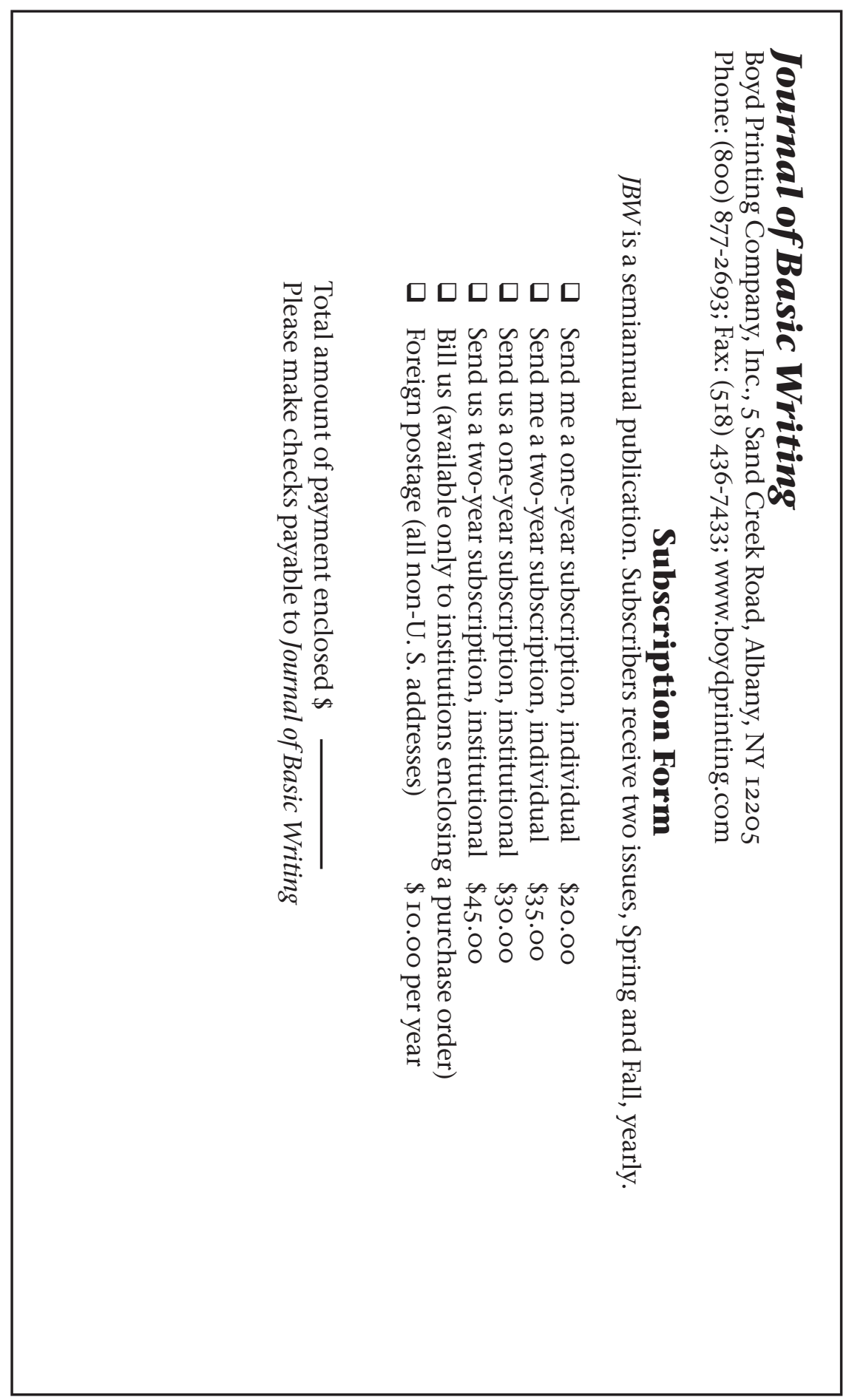



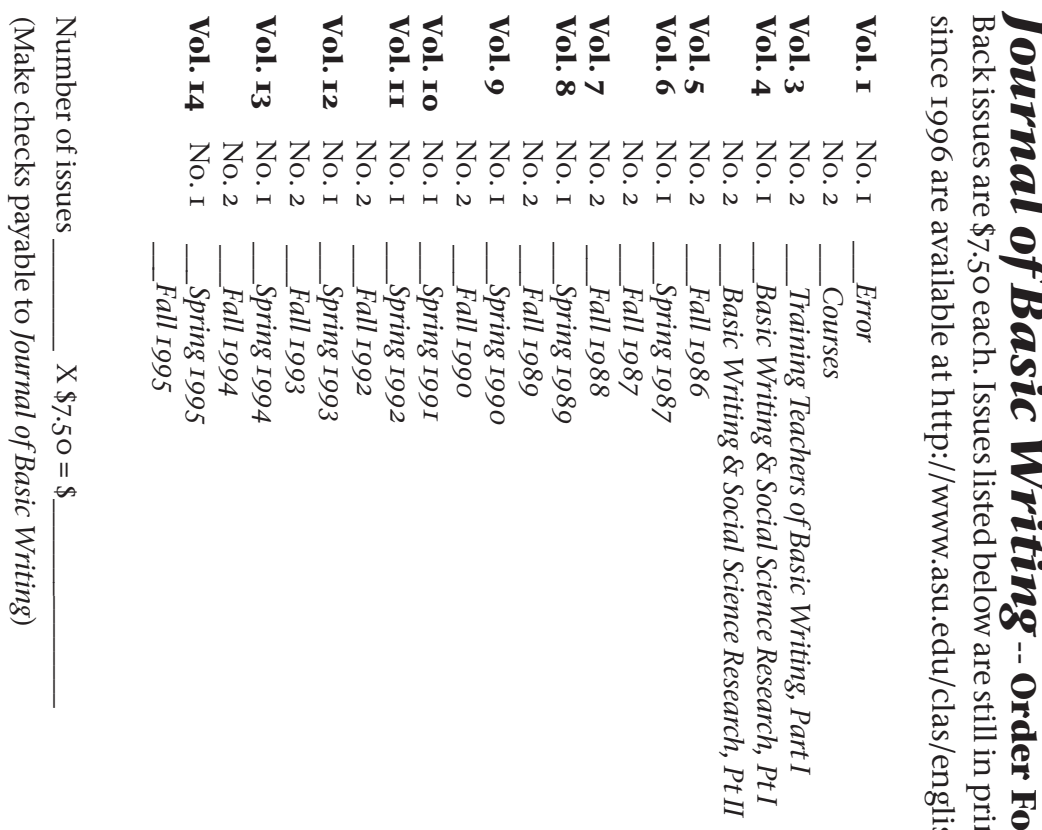

$\approx 0$

ڤે

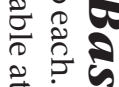
$\stackrel{+}{\circ}$ 辛尽

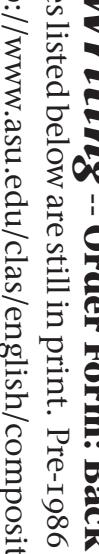

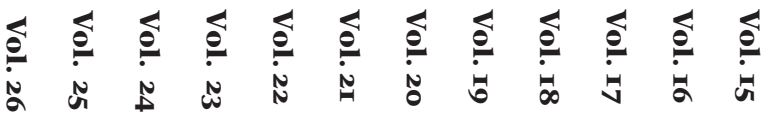

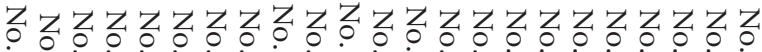

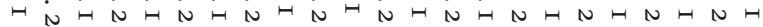

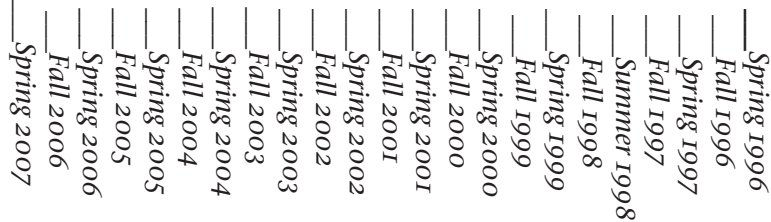

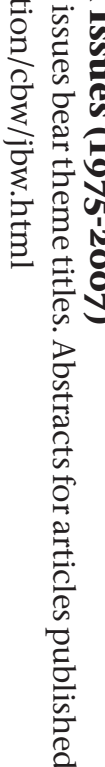




\section{How is this publication thinking about the future?}

\section{By becoming part of the past.}

This publication is available from

ProQuest Information and Learning in one or more of the following ways:

- Online, via the ProQuest information service

- Microform

- CD-ROM

- Via database licensing

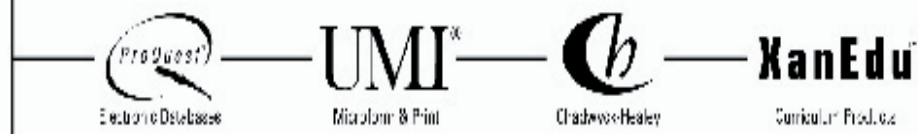

Fur unsterintormation, rall

I-800-52I-0600, cxt, 2888 (US) ur 0I-734-76I-4700 (1nterustioust) sonv.il.procpuest.rom

From:Pro Cuest 


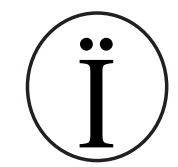

The paper used in this publication meets the minimum requirements of the American National Standard for Information Science Permanence of Paper for Printed Library Materials, ANSI Z39.48-1984.

The text stock is also recycled. 